\author{
UNIVERSIDADE DE SÃO PAULO \\ FACULDADE DE ODONTOLOGIA DE BAURU
}

KAREN ZAVARO BALASSIANO

\begin{abstract}
ANÁLISE COMPARATIVA DA AÇÃO DE ANABOLIZANTES EM GENGIVA E SISTEMA REPRODUTOR DE RATOS (Rattus norvegicus)
\end{abstract}



KAREN ZAVARO BALASSIANO

\section{ANÁLISE COMPARATIVA DA AÇÃO DE ANABOLIZANTES EM GENGIVA E SISTEMA REPRODUTOR DE RATOS \\ (Rattus norvegicus)}

Tese apresentada à Faculdade de Odontologia de Bauru da Universidade de São Paulo para obtenção do título de doutor em Odontologia

Área de Concentração: Patologia Bucal.

Orientador: Prof. Dr. Luís Antônio de Assis Taveira. 
Balassiano, Karen Zavaro

Análise comparativa da Ação de anabolizantes em gengiva e sistema reprodutor de ratos (Rattus norvegicus) / Karen Zavaro Balassiano. - Bauru. 2007.

137p. : il.; $30 \mathrm{~cm}$

Tese. (Doutorado) - Faculdade de Odontologia de Bauru. Universidade de São Paulo.

Orientador: Prof. Dr. Luís Antônio de Assis Taveira

Autorizo, exclusivamente para fins acadêmicos e científicos, a reprodução total ou parcial desta tese, por processos fotocopiadores e outros meios eletrônicos.

Assinatura:

Data:

Comitê de Ética da FOB-USP

Protocolo ${ }^{\circ}$

Data: 06/09/2007. 




\section{DEDICATÓRIA}

Durante dois anos senti muitas saudades, uma vontade imensa de correr para casa para passarmos apenas o fim de semana juntos. Amadureci e entendi que apesar de não estarmos fisicamente em contato, sentia vocês no meu coração sempre. Confesso...no meu coração bem apertado de saudades!!! Mas nesse período pude refletir em todas as suas qualidades, as que eu já conhecia e outras que descobri. Também refleti quanto aos meus defeitos e lhes digo que hoje sou uma pessoa melhor. No entanto, não teria condições de enxergá-los, reconhecê-los e melhorá-los se não tivesse vocês ao meu lado em todos os momentos. Obrigada por tudo!!! Amo vocês!!!

Dedico este trabalho aos meus pais SALIM e SILVIA, meus irmãos ALEXANDRE e DANIELLE, meus cunhados ILANA $e$ MAURICIO e aos meus tesouros CAROLINE, MIRELA, BERNARDO e DAFNE. 



\section{A amizade se dá de presente...}

A amizade se dá de presente sem esperar nada em troca.

A amizade se reafirma sem sentir qualquer temor nem dúvida alguma.

A amizade compreende as coisas que as palavras não podem expressar - saber ler um gesto, um olhar.

A amizade é um presente e seu valor não pode ser calculado - a não ser pelo coração

Aos meu amigos Melaine, Milton, Erikinha, Breno, Ana Carolina e Diego. 



\section{AGRADECIMENTOS PESSOAIS}

Ao meu querido orientador, Prof. Dr. Luís Antônio de Assis Taveira, pela atenção, carinho, amizade e palavras que consolaram em momentos difíceis. Seu bom humor e brincadeiras são contagiantes e necessários para conseguirmos viver com maior leveza. Obrigada!! À sua esposa Denise, por ser essa pessoa tão tranqüila e querida!!!

À minha querida amiga Simone de Queiroz Chaves Lourenço, pela sua valiosa amizade!!! Seu amparo e conversas foram essenciais para que pudesse ver que sempre há o lado bom das coisas. Seu caráter e profissionalismo serão exemplos que nunca esquecerei. Ao amigo Eduardo Lourenço, pela sua disponibilidade sempre!!!! Obrigada pela sua ajuda e paciência!!! E claro, ao Bernardo, por ser tão especial e pela alegria que leva para vocês!!!

Aos professores da Disciplina de Patologia, Prof. Dr. Alberto Consolaro, Profa. Dra. Denise de Oliveira e Profa. Dra. Vanessa Lara, pelo carinho e atenção.

Aos amigos do departamento de Histologia. Aos Prof. Dr. Rumiu e Prof. Dr. Gerson, pela atenção e disponibilidade. À Tânia e Dani, pela grande ajuda e carinho com que me receberam. Aos amigos Carlos Eduardo, Samuel e Marcela.

Aos amigos do departamento de Anatomia. Ao Prof. Dr. Jesus, pela sua disponibilidade, atenção e carinho. Ao Prof. Dr. Tom, pela sua atenção e carinho. Aos amigos Luís, Erivan e Geraldo.

Aos amigos do departamento de Anatomia - UNESP/Botucatu - Prof. Francisco e Prof. Sérgio pela disponibilidade e atenção com que me receberam em seu departamento; e ao amigo Luis Gustavo, pela boa vontade incondicional. Muito obrigada pela sua ajuda!!! 

À amiga Cristina, pelo carinho, amizade, risadas e disponibilidade com que sempre me atendeu e claro, seus abraços de bom dia todas as manhãs!!!

À Fatiminha, por sempre me ajudar e não medir esforços para isso!!! $E$ pelo seu carinho e amizade!!! Obrigada !!!

À Marilza, pela sua paciência sempre, mesmo quando insistíamos em atrapalhar o seu trabalho!!!

À minha querida amiga Melaine, pela sua amizade!!! Amiga, te amo!!! Obrigada por todos o momentos em que passamos e curtimos juntas, pelas nossas conversas, pelo seu apoio e pelo seu companheirismo nesses dois anos!!!

Á minha querida amiga Érika, pela nossa intensa amizade e pelos nossos "papos-cabeça"!!! Adorei a oportunidade de podermos nos conhecer melhor e pude ver o quanto você é especial. Ao querido amigo Breno, pela sua sinceridade $e$ amizade!!!

Ao meu amigo Milton, pelo seu carinho e por ser essa pessoa tão simples e cativante!!! Aprendi muito com você...com a sua maneira de ver as coisas, o seu jeito calmo por fora, mas que por dentro já sabe exatamente como vai lhe dar com a situação. À Aline, pela sua amizade e pelos momentos em que estávamos todos juntos!!!

Aos amigos Ana Carolina e Diego, pela amizade e companheirismo e pelos momentos agradáveis em que passamos juntos!!! E por serem pessoas tão espontâneas e especiais!!!

À minha querida Leda, por ser uma pessoa tão grande e bonita; e ao mesmo tempo simples e humilde. Sua amizade é muito especial!!!

Aos amigos de Doutorado, Gisele, Michele, Roberta, Sylvie e Tiago, pelo companheirismo e amizade nesses dois anos.

Aos amigos do Mestrado: Aroldo, Bruno, Maria Carolina, Carine, Gastão e Patrícia, pelos momentos alegres e pelo bom humor de vocês!!! 

Aos amigos do Doutorado "novo": Renata, Simone, Érika Sinara, Janaína e Eliane, pelos bons momentos.

Aos amigos conquistados durante esses dois anos em Bauru: Rosário, Erick, Marta, Suzana, Manoela, Ludmila, Laércio, Fernanda, Ana, Karen, Lívia e Andréa.

$E$ todos aqueles que, indiretamente, ajudaram na realização deste trabalho. Obrigada!!! 



\section{AGRADECIMENTOS INSTITUCIONAIS}

À Coordenação de Aperfeiçoamento de Pessoal de Nível Superior (CAPES), pelo apoio ao programa de Pós-graduação e pela bolsa de doutorado recebida.

Ao Departamento de Estomatologia da Faculdade de Odontologia de Bauru.

À Disciplina de Patologia.

À Disciplina de Histologia/Embriologia.

À Direção da Faculdade de Odontologia de Bauru e a Comissão de Pós-graduação.

À Biblioteca da Faculdade de Odontologia de Bauru, Universidade de São Paulo. 



\section{RESUMO}

Os esteróides anabólicos-androgênicos (EAA) se caracterizam como um grupo de compostos naturais e sintéticos formados a partir da testosterona e seus derivados e foram desenvolvidos com finalidade terapêutica. No entanto, a partir da década de 90 o seu uso tem sido considerado um problema de saúde pública; e o seu consumo aumentado entre atletas profissionais e amadores que usam a medicação até 100 vezes acima da dose recomendada. Os efeitos adversos mais comuns relacionados ao uso dos EAA são alterações hepáticas, endócrinas, músculo-esqueléticas, cardiovasculares, imunológicas, reprodutivas, psicológicas, efeitos virilizantes e feminilizantes; e efeitos tóxicos. Apesar de diversos efeitos deletérios, os EAA em dose e freqüência adequada podem ter efeitos benéficos no reparo de feridas, revertendo os efeitos de corticosteróides. O objetivo deste trabalho foi avaliar os efeitos de doses suprafisiológicas (10mg/semana, por 60 dias) do EAA decanoato de nandrolona em 32 ratos (Rattus norvegicus), sendo divididos igualmente para o grupo experimental e controle (8 fêmeas e 8 machos para cada grupo) através da macroscopia, microscopia e morfometria. Os resultados mostraram que os animais do grupo controle ganharam mais peso ao final do tratamento do que os animais tratados. Os ovários e testículos apresentaram atrofia enquanto a hipertrofia foi observada nos úteros e próstatas, com diferença de peso significativa estatisticamente em todos os órgãos entre o grupo experimental e controle. Nos testículos, a contagem do número de células de Sertoli não apresentou diferença estatística, assim como no percentual de fibras colágenas entre o grupo experimental e controle. A média da altura das células epiteliais nas próstatas dos animais tratados apresentou-se maior que as do controle. Os ovários das ratas medicadas apresentaram diminuição de corpos lúteos e folículos atrésicos. Os resultados encontrados indicam que as altas doses do EAA decanoato de nandrolona causam alterações macroscópicas e morfológicas nos sistemas reprodutores de machos e fêmeas, podendo ser irreversíveis. O efeito benéfico do uso de EAA na síntese de colágeno não foi observado nos fragmentos de gengiva analisados.

Palavras-chave: Esteróides Anabólicos-androgênicos, Testículos, Próstatas, Ovários, Úteros, Gengiva. 



\begin{abstract}
Comparative analysis of the action of anabolic steroids on the gingiva and
\end{abstract} reproductive system of rats (Rattus norvegicus)

The anabolic-androgenic steroids (AAS) are characterized as a group of natural and synthetic compounds formed from testosterone and derivatives, and have been developed for therapeutic purposes. However, after the 1990s, their utilization has been considered a public health problem and the intake increased among professional and amateur athletes, who ingest up to 100 times the recommended dose of the drug. The most common adverse effects related to utilization of AAS are hepatic, endocrine, muscle-skeletal, cardiovascular, immunological, reproductive and psychological alterations; masculinizing and feminizing effects; and toxic effects. Despite the several harmful effects, utilization of AAS at adequate dose and frequency may have beneficial effects on wound repair, reverting the effects of corticosteroids. This study evaluated the effects of supraphysiological doses (10mg/week, for 60 days) of the AAS nandrolone decanoate in 32 rats (Rattus norvegicus), equally divided into experimental and control groups (8 females and 8 males for each group), by macroscopic, microscopic and morphometric analyses. The results revealed that animals in the control group gained more weight at treatment completion than treated animals. The ovaries and testicles presented atrophy, and hypertrophy of uterus and prostates was observed, with statistically significant difference in weight in all organs between the experimental and control groups. In the testicles, counting of the number of Sertoli cells and the percentage of collagen fibers did not present statistically significant difference between the experimental and control groups. The mean height of epithelial cells in the prostates of treated animals was greater in treated animals than in the control group. The ovaries of treated rats exhibited reduction in corpora lutea and atresic follicles. The results indicated that high doses of AAS nandrolone decanoate caused macroscopic and morphological alterations in the reproductive systems of males and females, which may be irreversible. The beneficial effect of utilization of AAS on the collagen synthesis was not observed on gingival fragments analyzed.

Keywords: Anabolic-androgenic Steroids; Testis, Prostates, Ovaries, Uterus, Gingiva. 



\section{LISTA DE ILUSTRAÇÕES}

\section{- FIGURAS}

Figura 1 - Retículo de integração II Zeiss ${ }^{\circledR}$ sobre um dos campos coletados na gengiva (Tricrômico de Mallory obj. 100x).

Figura 2 - Campos selecionados aleatoriamente nos fragmentos de gengiva seguindo a extensão do epitélio (Tricrômico de Mallory - obj. 10x) .59

Figura 3 - Delineamento do miométrio (1) e endométrio (2) para obtenção da área dos mesmos - útero do grupo controle (HE obj. $2,5 \mathrm{x})$

Figura 4 - Mensuração de oito pontos no miométrio (1) e endométrio (2) para obtenção da espessura dos mesmos - útero do grupo experimental (HE obj. 2,5x). 63

Figura 5 - Túbulo seminífero em fase de pré-espermiação (Tricrômico de Masson - obj. 20x)

Figura 6 - Túbulo seminífero em fase de pós-espermiação (Tricrômico de Masson - obj. 20x).

Figura 7 - Célula de Sertoli - setas (Tricrômico de Masson - obj. 100x)

Figura 8 - Ácinos na região distal da próstata (HE - obj. 20x) 73

Figura 9 - Ácinos na região intermediária da próstata (HE - obj. 20x) .73

Figura 10 - Útero do grupo controle antes da fixação (fêmea 31).................77

Figura 11 - Útero do grupo experimental antes da fixação (fêmea 15)...........77

Figura 12 - Ovários do grupo controle antes da fixação (fêmea 30)..............79

Figura 13 - Ovários do grupo experimental antes da fixação (fêmea 14)........79

Figura 14 - Testículos do grupo controle antes da fixação (macho 24)..........81

Figura 15 - Testículos do grupo experimental antes da fixação (macho 6).....81

Figura 16 - Próstata do grupo controle antes da fixação (macho 24)..............83

Figura 17 - Próstata do grupo experimental antes da fixação (macho 7)........83 

Figura 18 - Ovário do grupo controle exibindo morfologia normal (esq.) e ovário do grupo experimental exibindo menor tamanho, poucos folículos e corpo lúteo em regressão (dir.) - HE obj. 2,5x 109

Figura 19 - Epitélio ovariano do grupo experimental variando de cúbico simples a cilíndrico pseudoestratificado - HE obj. 10x. 109

Figura 20 - Corpo lúteo do ovário do grupo experimental (HE obj. 10x)......111

Figura 21 - Corpo lúteo do ovário do grupo experimental exibindo regressão e atividade macrofágica (HE obj. 40x).

Figura 22 - Folículos atrésicos do ovário do grupo experimental - HE obj. $10 \mathrm{x}$

Figura 23 - Célula com hipertrofia (seta verde) e figuras sugestivas de morte celular desprendidas no lume e circundadas pelo halo amarelo em folículo atrésico do ovário do grupo experimental - HE obj. 40x..113

\section{- GRÁFICOS}

Gráfico 1 - Diferença do ganho de peso entre machos e fêmeas, do grupo experimental e controle.

Gráfico 2 - Diferença de peso dos testículos e próstatas entre o grupo experimental e controle.

Gráfico 3 - Diferença de peso dos ovários e úteros entre o grupo experimental e controle. .93

Gráfico4 - Diferença da espessura do miométrio e endométrio entre o grupo experimental e controle.

Gráfico 5 - Diferença da área do miométrio e endométrio entre o grupo experimental e controle. .96

Gráfico 6 - Diferença do números de células de Sertoli nos túbulos em fase de pré-espermiação e pós-espermiação nos grupos experimental e controle 100

Gráfico 7 - Diferença das alturas celulares das glândulas da região distal e intermediária entre os grupos experimental e controle. .103

Gráfico 8 - Diferença do percentual de fibras colágenas dos machos e fêmeas, entre os grupos experimentais e controles. 106 



\section{LISTA DE TABELAS}

Tabela 1 - Peso dos machos no início e ao final do experimento, ganho e percentual de peso.

Tabela 2 - Peso das fêmeas no início e ao final do experimento, ganho e percentual de peso.

Tabela 3 - Análise estatística da diferença de ganho de peso entre fêmeas e machos do grupo experimental; e fêmeas e machos do grupo controle. .88

Tabela 4 - Análise estatística da diferença de peso adquirido entre o grupo experimental e controle, nos diferentes gêneros.

Tabela 5 - Peso dos testículos e próstatas do grupo experimental e controle ao final do experimento.

Tabela 6 - Análise estatística da diferença de peso dos testículos e próstatas entre o grupo experimental e controle.

Tabela 7 - Peso dos ovários e úteros do grupo experimental e controle ao final do experimento

Tabela 8 - Análise estatística da diferença de peso dos ovários e úteros entre o grupo experimental e controle

Tabela 9 - Medidas da área e espessura do endométrio e miométrio para o grupo experimental e controle.

Tabela 10 - Análise estatística da diferença da área e espessura no endométrio e miométrio entre os grupos experimental e controle.

Tabela 11: Soma do número de células de Sertoli em 10 túbulos seminíferos na fase pré-espermiação e em 10 túbulos na pós-espermiação. 99

Tabela 12 - Análise estatística da diferença no número de células de Sertoli nos túbulos em fase de pré-espermiação e pós-espermiação nos grupos experimental e controle.

Tabela 13 - Análise estatística da diferença no número de células de Sertoli entre os grupos experimental e controle nos túbulos em fase de pré-espermiação e pós-espermiação.

Tabela 14 - Média das alturas celulares das glândulas da região distal e intermediária. 102

Tabela 15: Análise estatística da diferença das alturas celulares das glândulas da região distal e intermediária entre os grupos experimental e controle..103 

Tabela 16 - Análise morfométrica das fibras colágenas nas gengivas dos machos no grupo experimental e controle...............................................104

Tabela 17 - Análise morfométrica das fibras colágenas nas gengivas das fêmeas no grupo experimental e controle...................................................105

Tabela 18 - Análise estatística da diferença do percentual de fibras colágenas entre os grupos experimentais e controles dos machos e fêmeas.................106 

INTRODUÇÃO

2

REVISÃO DA LITERATURA

4.1 SELEÇÃO DA AMOSTRA 53

4.2 METODOLOGIA 54

4.2.1 Aplicação da medicação $\quad 54$

4.2.2 Anestesia dos animais $\quad 54$

4.2.3 Eutanásia e remoção dos órgãos 54

4.2.4 Macroscopia das peças $\quad 55$

4.2.5 Colorações histoquímicas $\quad 55$

$4.3 \quad$ ANÁLISE DOS RESULTADOS 57

4.3.1 Análise macroscópica $\quad 57$

4.3.2 Análise morfológica $\quad 57$

4.3.3 Análise morfométrica $\quad \mathbf{5 7}$

$\begin{array}{lll}\text { 4.3.2.1 Gengivas } & 57\end{array}$

$\begin{array}{lll}\text { 4.3.2.2 Úteros } & 61\end{array}$

4.3.2.3 Testículos $\quad 65$

$\begin{array}{lll}\text { 4.3.2.4 Próstatas } & 71\end{array}$

$\begin{array}{lll}5 & \text { RESULTADOS } & \mathbf{7 7}\end{array}$

5.1 ANÁLISE MACROSCÓPICA DOS ÓRGÃOS 77

5.1.1 Úteros 77

$\begin{array}{lll}5.1 .2 & \text { Ovários } & \mathbf{7 9}\end{array}$

$\begin{array}{lll}5.1 .3 & \text { Testículos } & \mathbf{8 1}\end{array}$

5.1.4 Próstatas 83

5.2 PESO GERAL E DOS ÓRGÃOS DOS ANIMAIS 85

5.2.1 Peso geral dos animais 85

5.2.2 Peso dos órgãos masculinos $\quad 90$

5.2.3 Peso dos órgãos femininos 92

5.3 ANÁLISE MORFOMÉTRICA 94

5.3.1 Área e espessura do miométrio e endométrio 94 

5.3.2 Contagem das células de Sertoli 98

$\begin{array}{lll}\text { 5.3.3 Próstatas } & 102\end{array}$

$\begin{array}{lll}\text { 5.3.4 Gengivas } & 104\end{array}$

5.4 ANÁLISE MORFOLÓGICA DOS OVÁRIOS 107

6 DISCUSSÃO 117

7 CONCLUSÃO 125

REFERÊNCIAS $\quad 129$

$\begin{array}{ll}\text { ANEXO } & 137\end{array}$ 

1 INTRODUÇÃO 


\section{1 - INTRODUÇÃO}

Os esteróides anabólicos-androgênicos (EAA) se caracterizam como um grupo de compostos naturais e sintéticos formados a partir da testosterona e seus derivados; e são importantes fármacos no tratamento de diferentes condições médicas como, deficiências no crescimento, desordens sanguíneas, osteoporose, síndrome de Turner, câncer de mama, entre outras (BASARIA et al., 2001; EVANS, 2007).

O primeiro relato da utilização de EAA com objetivos não terapêuticos, como auxílio na estética corporal, ocorreu em 1954, na Áustria. Desde então, seu consumo vem aumentando sendo considerado um problema de saúde pública (BARRET e HARRIS, 1993). Atletas profissionais e amadores utilizam-nos com o objetivo de aumentar massa muscular, melhorar o desempenho físico e a estética corporal (BARRETT e HARRIS, 1993; CREUTZBERG e SCHOLS, 1999; CUNHA et al., 2004).

O aumento do uso dos EAA tem despertado a atenção de profissionais de saúde e pesquisadores, devido ao uso incorreto e a idade com que os usuários iniciam seu consumo. Bahrke et al. (1998) relataram o consumo variando entre $4 \% \mathrm{e}$ $12 \%$ em estudantes do gênero masculino que cursavam o último ano em escolas secundárias nos EUA. Em um estudo realizado em quatro escolas públicas de Massachusetts, em 1998, constatou-se que 2,6\% de um total de 466 meninos e $2,8 \%$ de um total de 499 meninas, entre nove e 13 anos, utilizavam anabolizantes (FAIGENBAUM et al., 1998). Penatti et al. (2005) indicaram um aumento no uso de EAA, especialmente em adolescentes do gênero feminino.

No Brasil, poucos estudos estimam a prevalência do uso indevido dos EAA. Macedo et al., em 1998, demonstraram através do estudo realizado em seis academias em Santa Maria - RS, que 2\% em 305 praticantes de musculação eram usuários de EAA. Quase a totalidade de atletas recreacionais e competitivos entrevistados em 8 academias de musculação de Porto Alegre afirmaram estarem usando ou já terem usado EAA (DA SILVA e CZEPIELEWSKI, 2001). Da Silva et al. (2007) constataram a utilização atual ou pregressa de EAA em 11,1\% (32/288) dos praticantes de musculação de Porto Alegre entrevistados, sendo a quase totalidade caracterizada pelo gênero masculino. 
Diversos usuários de EAA consomem diferentes drogas simultaneamente com os anabolizantes, como estimulantes, diuréticos, insulina, entre outros; e em doses suprafisiológicas que podem alcançar até 100 vezes a dose terapêutica (CLARK e FAST, 1996). Embora seja possível destacar vários benefícios do uso de anabolizantes como: aumento da massa muscular, da força física, deposição de cálcio nos ossos, diminuição de gordura no corpo, inibição dos efeitos catabólicos na massa muscular esquelética, os efeitos maléficos são numerosos e variam desde comportamentais até alterações no fenótipo.

Os efeitos adversos mais comuns relacionados ao uso dos EAA são alterações hepáticas, endócrinas, músculo-esqueléticas, cardiovasculares, imunológicas, reprodutivas, psicológicas (THEIN et al., 1995), efeitos virilizantes e feminilizantes, mediados pelos metabólitos estrogênicos; e efeitos tóxicos.

Dentre os efeitos virilizantes, salientam-se o aumento da libido, aumento do pênis, tom de voz mais grave, distribuição masculina dos pêlos pubianos, aumento de secreção das glândulas sebáceas e aumento dos pêlos faciais. Nas mulheres, destaca-se a irreversibilidade do aumento do clitóris e alteração da voz (BRUNTON et al., 2006). A administração do hormônio exógeno, a partir de 15 a 150 mg/dia, já causa significativa diminuição da testosterona plasmática, intensificando os efeitos femilinizantes, como atrofia testicular e azoospermia por inibição da secreção de gonodotrofina e pela conversão de andrógenos em estrógenos (BRUNTON et al., 2006). Doses equivalentes a 1000mg/dia já são relatadas na literatura podendo levar a danos irreversíveis e até a morte de seus usuários, uma vez que os receptores específicos farmacológicos são saturados com doses bem inferiores a estas (THEIN et al., 1995).

Apesar de diversos efeitos prejudiciais, os EAA têm recebido grande atenção devido aos seus efeitos benéficos em reparo de feridas. Quando administrados no pré ou pós-operatório, os EAA revertem os efeitos deletérios dos corticosteróides no reparo de anastomoses intestinais experimentais (KIM et al, 1993). Um amplo reparo foi observado em alguns tipos de ulcerações isquêmicas com o uso de estanozolol (FALANGA et al, 1991; KIRSNER et al, 1993). No entanto, poucas investigações com o uso do estanozolol ou outros anabolizantes em reparo de feridas e na estimulação da síntese de colágeno são encontradas na literatura.

Os relatos de estudos dos efeitos nocivos de doses acima do recomendado de EAA no sistema reprodutor feminino e masculino são ainda 
escassos na literatura; e embora seja possível observar trabalhos que demonstrem os efeitos benéficos dos EAA na síntese de colágeno, não é possível localizar relatos desse benefício no tecido gengival. A partir do exposto, justifica-se estudar os efeitos de doses suprafisiológicas do decanoato de nandrolona no sistema reprodutor feminino e masculino; e na síntese de colágeno em gengivas de ratos para que esses conhecimentos possam ser empregados futuramente na prevenção dos efeitos irreversíveis e tratamento dos reversíveis nos sistemas reprodutores e no auxílio de reparo em feridas e cirurgias periodontais. 
2 REVISÃO DE LITERATURA 


\section{2 - REVISÃO DA LITERATURA}

A testosterona caracteriza-se como principal hormônio masculino sintetizado pelas células de Leydig, nos testículos e é responsável pelo desenvolvimento e manutenção das características sexuais masculinas e do estado anabólico de tecidos. No gênero feminino, é produzida em pequena quantidade pelo corpo lúteo e sintetizada pelo córtex da supra-renal em ambos os gêneros (BRUNTON et al., 2006). Os efeitos andrógenos são responsáveis pelo crescimento do sistema reprodutor masculino e desenvolvimento de características sexuais secundárias, enquanto os efeitos anabólicos estimulam o aumento da massa muscular esquelética, aumento da concentração de hemoglobina, do hematócrito, da retenção de nitrogênio, redução dos estoques de gordura corporal e aumento da deposição de cálcio nos ossos (GHAPHERY, 1995; KUHN, 2002).

Durante o primeiro trimestre da vida intra-uterina, a ação andrógena da testosterona exerce o importante papel no desenvolvimento das características masculinas (BHASIN, 2001). Na puberdade, o hormônio se apresenta responsável pelas características masculinas secundárias, transformando meninos em homens. $\mathrm{Na}$ vida adulta, diversos processos fisiológicos são regulados pela testosterona incluindo o metabolismo de proteínas nos músculos, funções sexuais e cognitivas, eritropoese e metabolismo ósseo (BHASIN, 1996).

Os hormônios androgênicos são derivados do colesterol e formam a família dos esteróides da qual, além da testosterona, também fazem parte a progesterona, o estradiol, o cortisol, a aldosterona, entre outros (SULLIVAN, 1998; HAUPT, 1984). As gonadotrofinas hipofisárias luteinizantes (LH) e folículo estimulante $(\mathrm{FSH})$ regulam o crescimento testicular, a espermatogênese e a esteroidogênese. O LH aumenta a síntese de AMPcíclico nas células intersticiais do testículo, o que aumenta a conversão de colesterol para estrógenos. O FSH promove a espermatogênese e aumenta a atividade da $\mathrm{LH}$, aumentando a síntese de testosterona (BRUNTON et al., 2006).

A secreção de testosterona é regulada por "feedback" negativo. Quando há deficiência de testosterona, ocorre estímulo no hipotálamo que, através da secreção de hormônio liberador de gonadotrofinas, estimula a glândula pituitária a liberar LH e FSH aumentando a síntese de testosterona (BRUNTON et al., 2006). O 
excesso de testosterona suprime a secreção de ambas as gonadotrofinas, diminuindo a produção endógena do hormônio e da espermatogênese.

A testosterona não é substância ativa; na circulação age como próhormônio na formação de duas classes de esteróides: andrógenos 5-a-reduzidos (dihidrotestosterona), que são mediadores intracelulares da maioria das ações androgênicas; e estrógenos (estradiol), que potencializam alguns efeitos androgênicos, enquanto bloqueiam outros (BRUNTON et al., 2006). A testosterona é convertida em vários outros metabólitos ativos como estradiol, androsterona, 3- $\alpha-$ hidroxi-5-ß-androsta-17-ona e androstenediona.

As substâncias ativas, inclusive metabólitos reduzidos (dihidrotestosterona) atravessam a membrana celular e ligam-se com alta especificidade a receptores citoplasmáticos para esteróides. Uma vez formado o complexo hormônio-receptor, este se desloca ao núcleo, onde se liga ao DNA em uma região específica promovendo a transcrição e produção de proteínas específicas ou a repressão de certos genes (BRUNTON et al., 2006).

As células de Sertoli são células somáticas que se fixam na membrana basal do tubo seminífero e atingem a superfície do epitélio. São basicamente prismáticas ou piramidais, com cerca de $70 \mu \mathrm{m}$ de altura, embora os seus contornos se apresentem muito irregulares devido à presença de numerosas reentrâncias laterais onde se alojam os elementos da linha espermatogênica ou seminal. (JÉGOU, 1992). Constituem, após a puberdade, cerca de $10 \%$ das células do tubo seminífero ocupando uma posição estratégica que lhes permite um íntimo contacto com todos os elementos da linha germinativa situadas entre a membrana basal e a luz do mesmo. Ao microscópio de luz o citoplasma da célula de Sertoli é claro e apresenta-se preenchido pelos elementos da linha germinativa, não sendo possível observar os seus contornos. O núcleo apresenta contorno oval ou elipsóide, é claro e tem um nucléolo bem evidente. Embora o núcleo esteja em regra próximo da base da célula, sua posição e forma variam nas diferentes associações celulares da linha espermatogênica (CROSS e MERCER 1993). As células de Sertoli exercem a importante função de originar compartimentos onde se formam microambientes indispensáveis à espermatogênese (GRISWOLD, 1995; GRISWOLD, 1998). Além disso, fornecem suporte estrutural e metabólico necessário às células germinativas e controlam a nutrição das mesmas durante a espermatogênese, dado o seu íntimo 
contacto que com elas estabelecem; e fagocitam e digerem o citoplasma residual das espermátides, resultante da espermiogênese.

Desde o seu descobrimento, em 1932, numerosos derivados da testosterona, os esteróides anabólicos-androgênicos (EAA), foram sintetizados com o objetivo de maximizar os efeitos anabólicos do hormônio natural (HAUPT, 1984). Os EAA podem ser esterificados, alcalinizados ou ter seu anel básico modificado. Cada componente obtido é diferente estruturalmente da testosterona, e, portanto, também serão sua afinidade e eficácia de ligação com os receptores androgênicos (RA) e conseqüentemente seus efeitos anabólicos e androgênicos (THEIN et al., 1995). Os chamados apenas anabolizantes ou androgênios apresentam efeitos mistos, variando apenas a proporção androgênico anabólica; sendo assim, a forma mais correta de denominá-los é EAA, embora o termo mais conhecido seja anabolizantes.

Os EAA podem ser classificados em três categorias dependendo do tipo de modificação em sua estrutura. A esterificação de um ácido graxo no grupo hidroxila $17 ß$ caracteriza os EAA de classe A. Essa alteração aumenta a propriedade lipofílica por diminuir a polaridade da molécula, o que eleva suas propriedades androgênicas e ainda permite uma absorção mais lenta após a injeção intramuscular (BRUNTON et al., 2006).

Os derivados da classe B sofrem alquilação no grupo hidroxila $17 \alpha$ resultando em um sintético que pode ser administrado por via oral e com uma degradação hepática lenta (ROGOL, 1992; BRUNTON et al., 2006). Apesar da potencialidade desse grupo apresentar-se mais fraca do que os esteróides injetáveis ou de classe A, eles podem causar toxicidade hepática (BAGATELL, 1996).

Os esteróides sintéticos da classe $C$ sofrem alquilação nos anéis $A, B$ ou C de sua estrutura principal. Essa modificação leva a uma similaridade das propriedades com aqueles de classe $B$, porém com uma diminuição ou até inexistência no metabolismo hepático (BASARIA, 2001).

Durante a $2^{\mathrm{a}}$ Guerra Mundial a utilização dos EAA tinha finalidade terapêutica para deficiências nutricionais severas em soldados e também no tratamento de pacientes em condições terminais, como debilidade crônica, traumatismos, queimaduras, depressão, recuperação de grandes cirurgias e reparo de feridas (BROWSE et al. 1977; FALANGA et al., 1991; GHAPHERY, 1995; 
HOBERMAN, 1995). No entanto, somente na década de 50, os hormônios sintéticos obtiveram maior aceitação para o uso médico.

Diversos estudos clínicos têm mostrado sua utilização benéfica no hipogonadismo (BHASIN, 1997; BRODSKY, 1996, SNYDER, 2000), puberdade e crescimento retardados (SCHROOR, 1995), deficiência androgênica parcial em homens idosos, deficiência androgênica secundária a doenças crônicas, osteoporose (CONWAY, 2000), sarcopenia relacionada ao HIV em pacientes hipogonadais e eugonadais (RABKIN, 2000; GRINSPOON, 2000; SATTLER, 1999; SATTLER, 2002), reparo de feridas (FALANGA et al, 1991) e outras doenças.

Com a publicação, em 1945, do livro de Paul de Kruiff, "The Male Hormone", o uso da testosterona entre os atletas tornou-se comum em variadas modalidades; porém, o primeiro documento do uso de hormônios sexuais pelos atletas se deu em 1950, em um campeonato de levantamento de peso em Viena (Áustria) por atletas do time russo que usavam andrógenos para melhorarem sua performance e, a partir daí, o abuso destes agentes em esporte tornou-se difundido com este fim (HOBERMAN, 1995, YESALIS et al., 2000).

Alterações comportamentais, fisiológicas e morfológicas estão relacionadas com o uso indevido de diferentes EAA, seja com doses suprafisiológicas, uso prolongado ou uso simultâneo com outras drogas. Bronson et al. (1997) mostraram que doses acima do recomendado diminuem o tempo de vida de ratos machos. O estudo mostrou que $52 \%$ dos ratos tratados morreram antes de um ano de tratamento em comparação ao grupo controle, onde foram observadas $12 \%$ de mortes.

Diversos efeitos colaterais são descritos em órgãos androgêniodependente. Alguns achados indicam que a natureza e o grau dos efeitos na fisiologia da reprodução e no comportamento sexual dependem de como e quais os EAA são administrados. A administração de 17a-metiltestosterona, estanozolol ou metandrostenolona na dose de $7,5 \mathrm{mg} / \mathrm{kg}$, uma vez ao dia por duas semanas em ratas suprime o comportamento sexual e o cio; enquanto o mesmo tratamento com decanoato de nandrolona ou cipionato de testosterona suprime o cio, mas aumenta a receptividade sexual (BLASBERG et al., 1997).

A morfologia do sistema reprodutor feminino e masculino de animais experimentais também apresenta alterações durante o tratamento com EAA. Com a administração de EAA, o nível de testosterona endógena, hormônios gonadotróficos 
e globulina ligadora de hormônios sexuais diminuem, assim como o peso dos testículos, contagem e mobilidade dos espermatozóides (SHAHIDI, 2001). A administração de decanoato de nandrolona em macacas Cynomolgus resultou em aumento do peso do útero e da espessura do endométrio, alterações glandulares e mucometra (OBASANJO et al., 1998).

Fortunato et al. (2006) ao aplicarem uma dose 60 vezes maior de decanoato de nandrolona (uma vez por semana, por oito semanas) em ratos machos, observaram significante diminuição no peso dos testículos e aumento no peso do coração, rins e tireóide em relação ao grupo controle. Entretanto, o peso final dos ratos tratados não se mostrou significantemente diferente dos ratos do grupo controle. Noorafshan et al., (2005) observaram resultado semelhante nos testículos de ratos tratados com alta $(10 \mathrm{mg} / \mathrm{kg})$ dose da mesma droga por 14 semanas em relação ao grupo controle e o grupo que recebeu baixa dose $(3 \mathrm{mg} / \mathrm{kg})$, assim como observaram diminuição de peso nas próstatas e atrofia dos seus componentes do grupo tratado com $3 \mathrm{mg} / \mathrm{kg}$ por 14 semanas em relação ao controle (KARBALAY-DOUST e NOORAFSHAN, 2006).

Takahashi et al. (2004) analisaram os efeitos endocrinológicos e patológicos do uso de anabolizantes em doses suprafisiológicas em 37 ratos Wistar com sete semanas de idade. As drogas usadas estavam 100 vezes acima da usual para um humano pesando $60 \mathrm{~kg}$ e foram distribuídas como se segue: grupo $A$, decanoato de nandrolona + acetato de metanolona + dromostanolona; grupo B, decanoato de nandrolona + solução salina; grupo C, solução salina. O nível de testosterona apresentou-se significantemente mais elevada no grupo A do que no $\mathrm{C}$, a Dihidrotestosterona estava mais elevada no grupo $A$ do que nos grupos $B$ e $C$, e o Estradiol-17ß mais elevado nos grupos A e B do que no grupo C. Na análise microscópica, coração, glândulas adrenais e testículos estavam severamente alterados. Os testículos dos ratos do grupo A mostraram escassez de espermatozóides no lume dos túbulos seminíferos e número reduzido de células de Leydig e de Sertolli. As próstatas apresentaram-se hipertrofiadas e com proliferação epitelial irregular e vacúolos com sedimentos amilóides no seu interior.

Alterações microscópicas em úteros e ovários em ratas adultas submetidas ao tratamento com decanoato de nandrolona foram observadas por Gerez et al. (2005) e por Mobini Far et al. (2007). Os ovários das ratas tratadas com o medicamento apresentaram ausência do corpo lúteo e destruição das unidades 
foliculares (GEREZ et al., 2005). Nos úteros também foram identificadas alterações como epitélio vacuolado e subjacente um estroma denso (GEREZ et al., 2005; MOBINI FAR et al., 2007). O epitélio variou de cilíndrico simples ou pseudoestratificado ao epitélio estratificado com células cúbicas (GEREZ et al., 2005). O endométrio apresentava-se fino e com escassas glândulas que mostravam aspecto tubular (GEREZ et al., 2005; MOBINI FAR et al., 2007).

Em estudo sobre os efeitos de doses suprafisiológicas de EAA no metabolismo do colágeno de 17 homens que utilizavam esteróides adquiridos de forma ilícita, Pärssinen et al.(2000) sugeriram que essas doses elevadas diminuem a degradação e aumenta a síntese de colágeno tipo I. Falanga et al. (1998) ao estudarem o estímulo da síntese de colágeno pelo Estanozolol, também chegaram a mesma conclusão que os autores citados anteriormente, sugerindo, ainda, que esses efeitos seria mediados pelo TGF-ß1 sendo antagônico aos efeitos deletérios dos corticosteróides, como diminuição da atividade fibroblástica e degradação das fibras colágenas. 
3 PROPOSIÇÃO 


\section{3 - PROPOSIÇÃO}

- Comparar o peso total dos animais tratados com decanoato de nandrolona (Deca-Durabolin ${ }^{\circledR}$ ) em relação ao grupo controle ao final do experimento.

- Analisar os efeitos da administração de dose suprafisiológica do esteróide anabólico-androgênico decanoato de nandrolona (Deca-Durabolin ${ }^{\circledR}$ ) nos úteros, testículos e próstatas de ratos (Rattus norvegicus) em desenvolvimento, por meio da morfometria e aspectos macroscópicos.

- Comparar aspectos morfológicos gerais e macroscópicos do efeito da administração de dose suprafisiológica do esteróide anabólico-androgênico decanoato de nandrolona (Deca-Durabolin ${ }^{\circledR}$ ) nos ovários de ratas (Rattus norvegicus) em desenvolvimento;

- Comparar, através da morfometria, o percentual de fibras colágenas presente nos fragmentos de gengivas dos grupos controle e experimental. 
4 MATERIAL E MÉTODOS 


\section{4 - MATERIAL E MÉTODOS}

\section{1 - Seleção da amostra}

O presente trabalho faz parte de um projeto de pesquisa realizado pelas disciplinas de Anatomia, Bioquímica e Patologia da Faculdade de Odontologia de Bauru - USP. A amostra foi composta por 32 ratos (Rattus norvegicus) da linhagem Wistar, sendo 16 machos e 16 fêmeas com idade de 60 dias, fornecidos pelo Biotério da Faculdade de Odontologia de Bauru da Universidade de São Paulo. Os animais foram distribuídos em 4 grupos com 8 animais cada, sendo dois grupos experimentais e dois grupos controles, nos quais os animais foram separados pelo gênero como segue:

- GCM - Grupo Controle Masculino;

- GCF - Grupo Controle Feminino;

- GEM - Grupo Experimental Masculino;

- GEF - Grupo Experimental Feminino.

No início do experimento os animais foram pesados e distribuídos para que os grupos formados ficassem com animais de pesos semelhantes. A seguir foi realizado um sorteio para identificação dos Grupos a que pertenceriam os animais. Durante toda a parte experimental, os animais foram pesados semanalmente para que uma comparação de ganho ou perda de peso pudesse ser realizada entre os diferentes grupos.

Os animais foram mantidos em gaiolas individuais com luminosidade da sala controlada por períodos de 12 horas de claro e escuro, através de um cronômetro e temperatura de aproximadamente $22^{\circ} \mathrm{C}$ controlada por um termômetro $\left(\right.$ Incoterm $\left.{ }^{\circledR}\right)$. Os animais do Grupo Controle receberam água e ração "ad libitum", e os do Grupo Experimental, uma média da ração consumida pelos animais do Grupo Controle, no dia anterior. O controle da ração foi realizado para que a diferença de consumo entre o grupo experimental e controle não influíssem no desenvolvimento dos músculos mastigatórios, posteriormente observados pela disciplina de Anatomia e para que não houvesse alteração no peso final dos animais. 


\section{2 - Metodologia}

\subsection{1 - Aplicação da medicação}

Os animais do Grupo Experimental receberam duas doses de decanoato de nandrolona (Deca-Durabolin ${ }^{\circledR}$ ) por semana, sendo $5 \mathrm{mg} / \mathrm{kg}$ de peso corporal cada aplicação, no horário entre 7:30h e 8:00h, às terças e sextas feiras, seguindo a metodologia de CUNHA et al. (2006). Esta dose é equivalente às doses elevadas, geralmente utilizadas por atletas, $600 \mathrm{mg} / \mathrm{semana}$ ou aproximadamente $8 \mathrm{mg} / \mathrm{kg}$ por semana (POPE \& KATZ, 1988). As aplicações foram realizadas no músculo gastrocnêmio esquerdo dos animais, por um período de sessenta dias (2 meses).

Os animais do Grupo Controle obtiveram tratamento semelhante, porém com aplicações de solução fisiológica estéril, no mesmo volume do anabolizante injetado nos animais do Grupo Experimental.

\subsection{2 - Anestesia dos animais}

Durante o experimento, caso algum animal estivesse agressivo e não permitisse a aplicação da medicação, eles eram anestesiados com injeções intramusculares de Xilazina $\left(10 \mathrm{mg} / \mathrm{kg}\right.$ - Anasedan $\left.^{\circledR}\right)$ associada a Quetamina $\left(50 \mathrm{mg} / \mathrm{kg}\right.$ - Dopalen $\left.^{\circledR}\right)$ na parte posterior da coxa, sendo esta metodologia recomendada pelo Biotério da Faculdade de Odontologia de Bauru - Universidade de São Paulo.

\subsection{3 - Eutanásia e remoção dos órgãos}

Os animais receberam injeção de anestésicos, com valores três vezes maiores ao descrito no tópico anterior para que os órgãos necessários para o presente trabalho pudessem ser retirados. Os órgãos removidos foram: fragmento 
de gengiva inserida vestibular na área de molares do lado direito, útero, ovários, lobo ventral das próstatas e testículos.

Todas as peças foram fotografadas com máquina digital Nikon 4500 utilizando um tripé de $10 \mathrm{~cm}$ para apoio e com a mesma aproximação para todas as fotos. Os úteros, ovários, próstatas e testículos foram pesados em balança digital (Mettler PB3002) e logo depois armazenados em frascos com formalina tamponada neutra a $10 \%$ por 36 horas a $4^{\circ} \mathrm{C}$.

\subsection{4. - Macroscopia das peças}

Após o período de 24 horas de fixação realizou-se a macroscopia das peças, seguindo as orientações do Laboratório de Histotécnica do Departamento de Patologia Bucal da Faculdade de Odontologia de Bauru - Universidade de São Paulo. As peças permaneceram mais 12 horas na fixação para que fossem desidratadas em álcool, diafanizadas em xilol e incluídas em parafina.

\subsection{5 - Colorações histoquímicas}

A partir dos blocos em parafina obtiveram-se um corte com $4 \mu \mathrm{m}$ de espessura dos úteros, ovários e próstatas; e dois cortes com a mesma espessura dos fragmentos de gengiva e testículos, sendo em seguida montados em lâminas de vidro. De cada espécime, uma lâmina foi corada pela técnica da hematoxilina e eosina, seguindo a metodologia padronizada pelo Laboratório de Histotécnica do Departamento de Patologia Bucal da Faculdade de Odontologia de Bauru Universidade de São Paulo. Os outros cortes dos fragmentos de gengiva foram submetidos à coloração do Tricrômico de Mallory, ao azul de anilina, para melhor visualização das fibras colágenas e para os espécimes dos testículos realizou-se a técnica do Tricrômico de Masson, ao verde luz, para melhor identificação das células de Sertoli. As duas técnicas seguiram a metodologia descrita abaixo: 


\section{Tricrômico de Mallory (ao azul de anilina)}

1. Desparafinização e hidratação dos cortes;

2. Pingar a solução de fucsina ácida $\left(2,5 \mathrm{~g}\right.$ em $100 \mathrm{~mL}$ de $\mathrm{H}_{2} \mathrm{O}$ destilada) na proporção 1:3, por 3 minutos;

3. Remover o excesso da solução de fucsina ácida;

4. Pingar a solução de Tricrômico de Mallory por 15 minutos;

Solução de Tricômico de Mallory

- Azul de anilina hidrossolúvel - 2,5g

- Orange G - $10 \mathrm{~g}$

- Ácido fosfotúngstico - 9g

- $\mathrm{H}_{2} \mathrm{O}$ destilada $-400 \mathrm{~mL}$

5. Lavar as lâminas em álcool 95\% para remover o excesso de corante;

6. Desidratação dos cortes;

7. Montagem das lâminas.

\section{Tricrômico de Masson (ao verde luz)}

1. Desparafinização e hidratação dos cortes;

2. Colodionar os cortes com ácido pícrico $1,22 \%$ por 30 minutos;

3. Lavar em $\mathrm{H}_{2} \mathrm{O}$;

4. Corar com hematoxilina por 15 minutos;

5. Lavar em $\mathrm{H}_{2} \mathrm{O}$ por 10 minutos e depois passar por $\mathrm{H}_{2} \mathrm{O}$ destilada;

6. Corar com a mistura fucsina-poceau por 10 minutos;

7. Lavar rapidamente em água acética $1 \%$;

8. Corar com orange g-molíbdico por 5 minutos;

9. Lavar em $\mathrm{H}_{2} \mathrm{O}$ destilada;

10. Corar com verde-luz por 5 minutos;

11. Desidratação dos cortes;

12. Montagem das lâminas 


\section{3 - Análise dos resultados}

\subsection{1 - Análise macroscópica}

Os pesos e as fotografias dos órgãos foram comparados para identificação de diferenças entre os grupos experimenta e controle.

\subsection{2 - Análise morfológica}

A análise microscópica foi realizada nos ovários onde foram observadas as seguintes características gerais:

- Integridade dos folículos;

- Presença ou ausência de figuras sugestivas de morte celular nos folículos;

- Presença ou ausência de corpo lúteo;

- Tipo de epitélio presente na superfície ovariana.

\subsection{3 - Análise morfométrica}

\subsubsection{1 - Gengivas}

Para a avaliação morfométrica das gengivas foi utilizado o microscópio Olympus ${ }^{\circledR} \mathrm{CH}-2$ com objetiva de imersão de $100 \mathrm{x}$ e ocular Kpl 8x Zeiss ${ }^{\circledR}$ contendo um retículo de integração II Zeiss ${ }^{\circledR}$, constituído por 10 linhas paralelas e 100 pontos simetricamente distribuídos dentro de uma área quadrada (Figura 1).

Os cortes corados com Tricrômico de Mallory foram selecionados para realização da morfometria devido à melhor evidenciação das fibras colágenas por essa coloração. Uma pessoa não participante deste trabalho identificou aleatoriamente as lâminas por letras para que a análise fosse realizada através de uma leitura cega. 
O percentual de fibras colágenas presente em cada fragmento foi obtido a partir da seleção de 10 campos do tecido conjuntivo logo abaixo ao epitélio, com objetiva de imersão de 100x. Os campos foram adquiridos ao acaso seguindo a extensão do epitélio como observado na Figura 2.

As fibras colágenas observadas nos pontos de interseção do retículo de integração foram contabilizadas, assim como os vasos sanguíneos, hemácias, células do tecido conjuntivo, fibras reticulares e espaços vazios. Caso fossem observados pontos de interseção em epitélio e em fibras de músculo esquelético, esses eram contados e posteriormente, para o cálculo do percentual das fibras colágenas, descartados. Ao final da contagem realizou-se o somatório dos pontos de interseção de todas as estruturas observadas nos 10 campos para que fosse encontrado o percentual de fibras colágenas. 


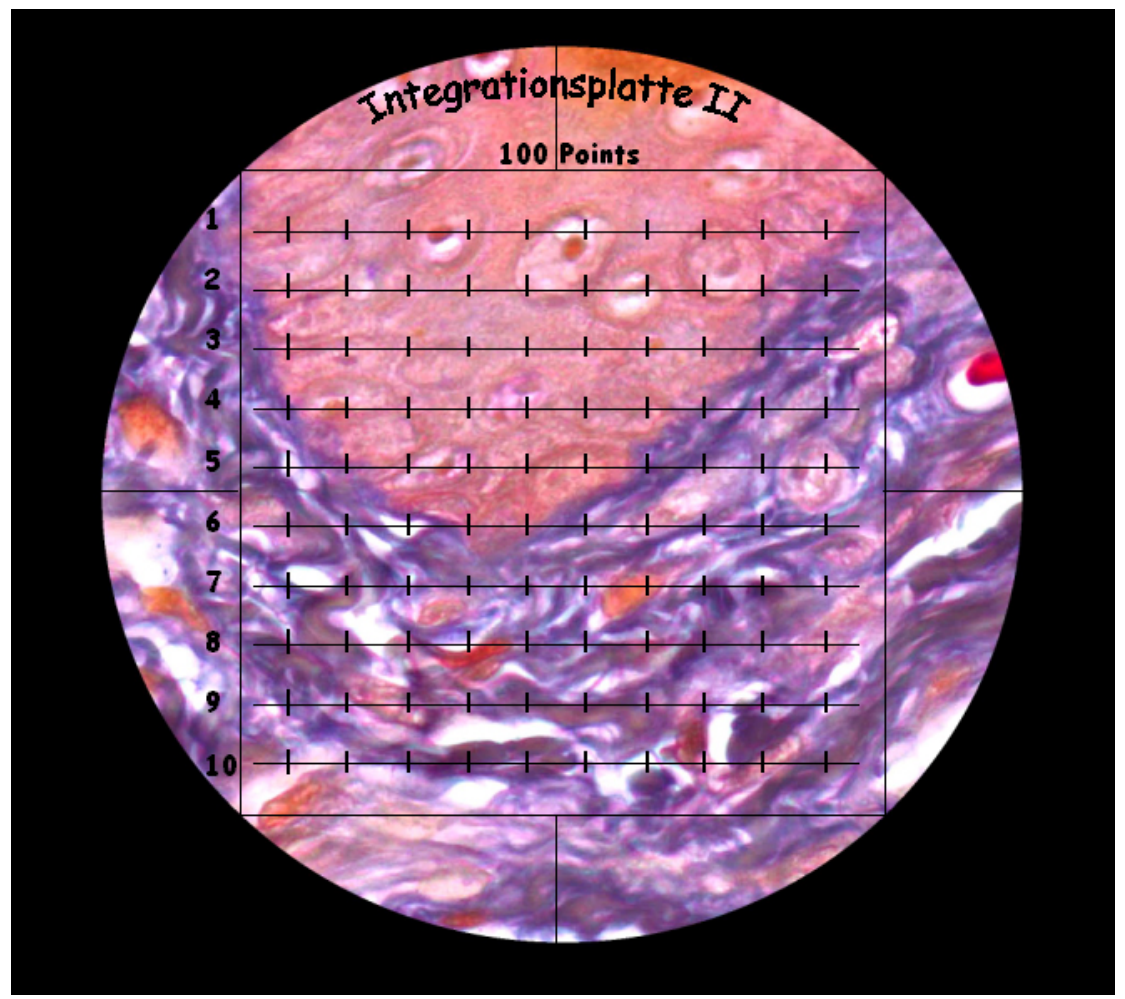

Figura 1 - Retículo de integração II Zeiss ${ }^{\circledR}$ sobre um dos campos coletados na gengiva (Tricrômico de Mallory obj. 100x).

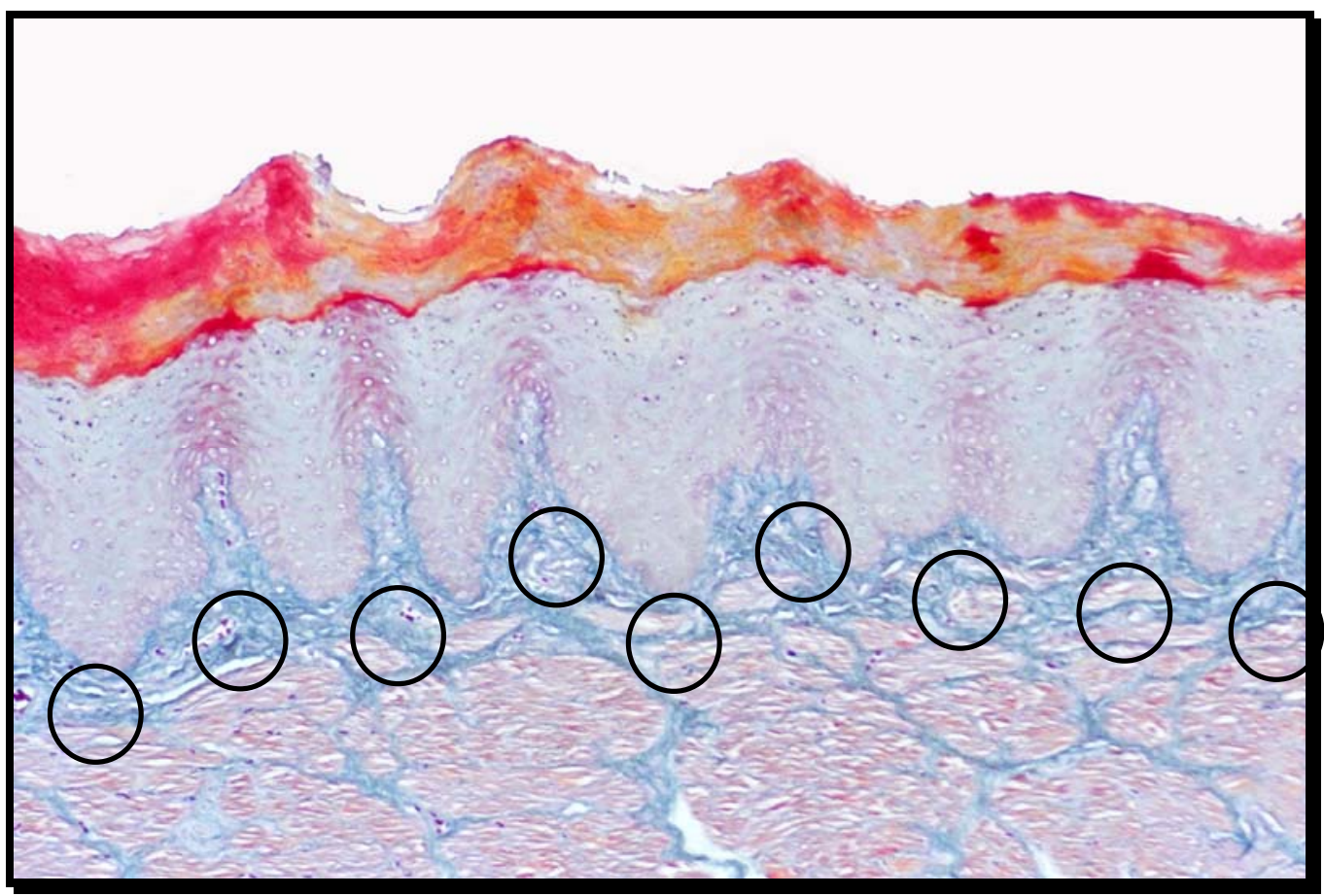

Figura 2 - Campos selecionados aleatoriamente nos fragmentos de gengiva seguindo a extensão do epitélio (Tricrômico de Mallory - obj. 10x) 


\subsubsection{2 - Úteros}

Para a análise morfométrica dos úteros, os cortes transversais corados em hematoxilina e eosina foram selecionados e um dos três fragmentos presentes na lâmina foi escolhido por sorteio para ser analisado. O corte foi observado ao microscópio óptico binocular Axioskop 2 Carl Zeiss ${ }^{\circledR}$ com objetiva de $4 x$ e através do programa de análise de imagem $\mathrm{KS} 300^{\circledR} 3.0$ a área e espessura do miométrio e endométrio foram obtidas.

A área do miométrio e endométrio foi obtida através do delineamento dessas estruturas, como observado na figura 3 e a espessura dos mesmos pela média de oito diferentes pontos medidos ao redor do miométrio e endométrio, como observado na figura 4. 


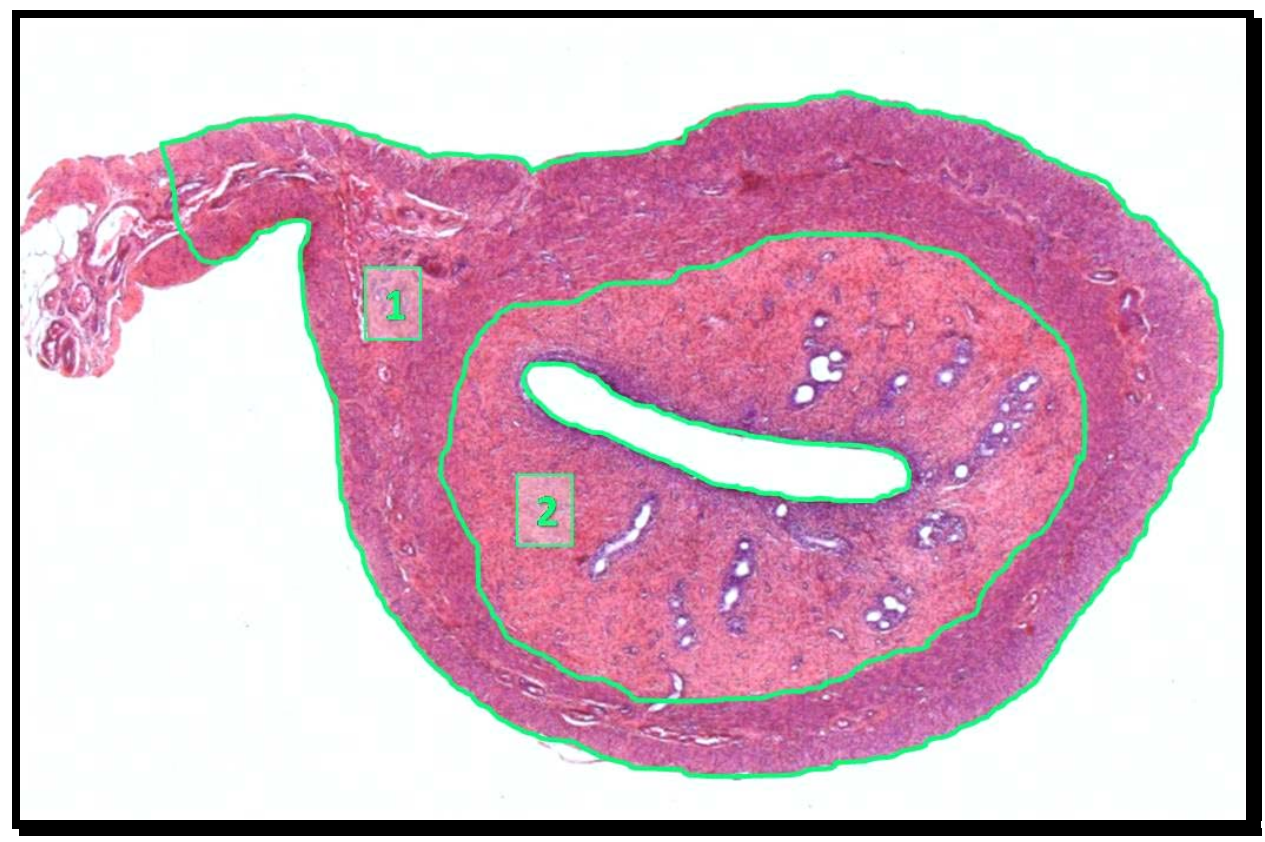

Figura 3 - Delineamento do miométrio (1) e endométrio (2) para obtenção da área dos mesmos - útero do grupo controle (HE obj. 2,5x).

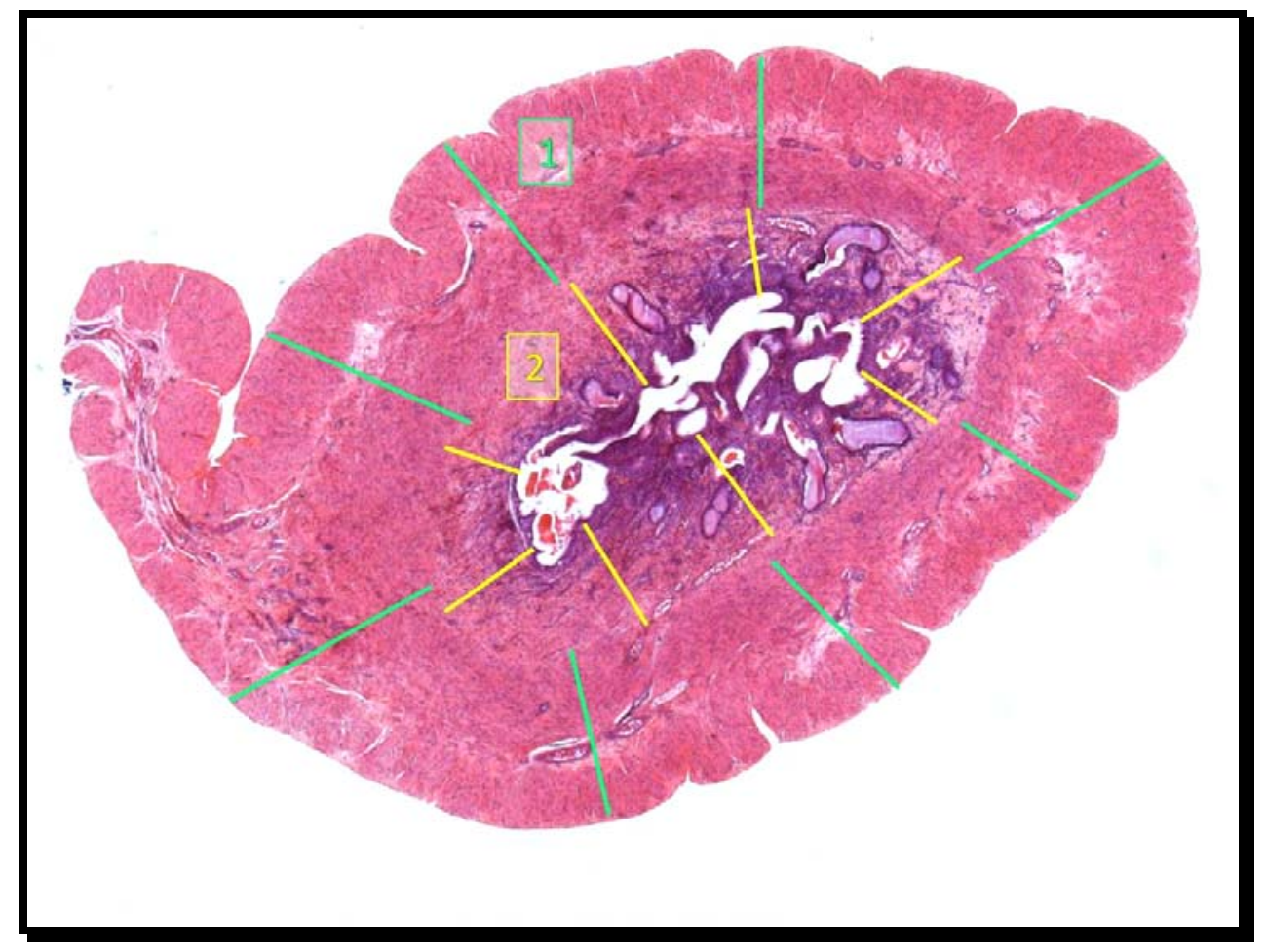

Figura 4 - Mensuração de oito pontos no miométrio (1) e endométrio (2) para obtenção da espessura dos mesmos - útero do grupo experimental (HE obj. 2,5x). 


\subsubsection{3 - Testículos}

Para contagem das células de Sertoli determinou-se usar os cortes transversais dos testículos corados com Tricrômico de Masson, onde um dos quatro fragmentos presentes na lâmina era sorteado. No fragmento, 20 túbulos seminíferos em fase de pré-espermiação (Figura 5) e 20 túbulos seminíferos em fase de pósespermiação (Figura 6) foram selecionados. Para essa análise utilizou-se microscópio Olympus ${ }^{\circledR} \mathrm{CH}-2$ com objetiva de imersão de 100x onde apenas os túbulos seminíferos mais circulares e que não apresentassem retração tecidual foram incluídos para contagem. As células de Sertoli foram identificadas pelo seu núcleo, de contorno oval ou elipsóide, claro e com nucléolo bem evidente e pela sua localização próxima da base da célula. Os núcleos com ausência do nucléolo, porém com as características compatíveis foram incluídos na contagem (Figura 7). 


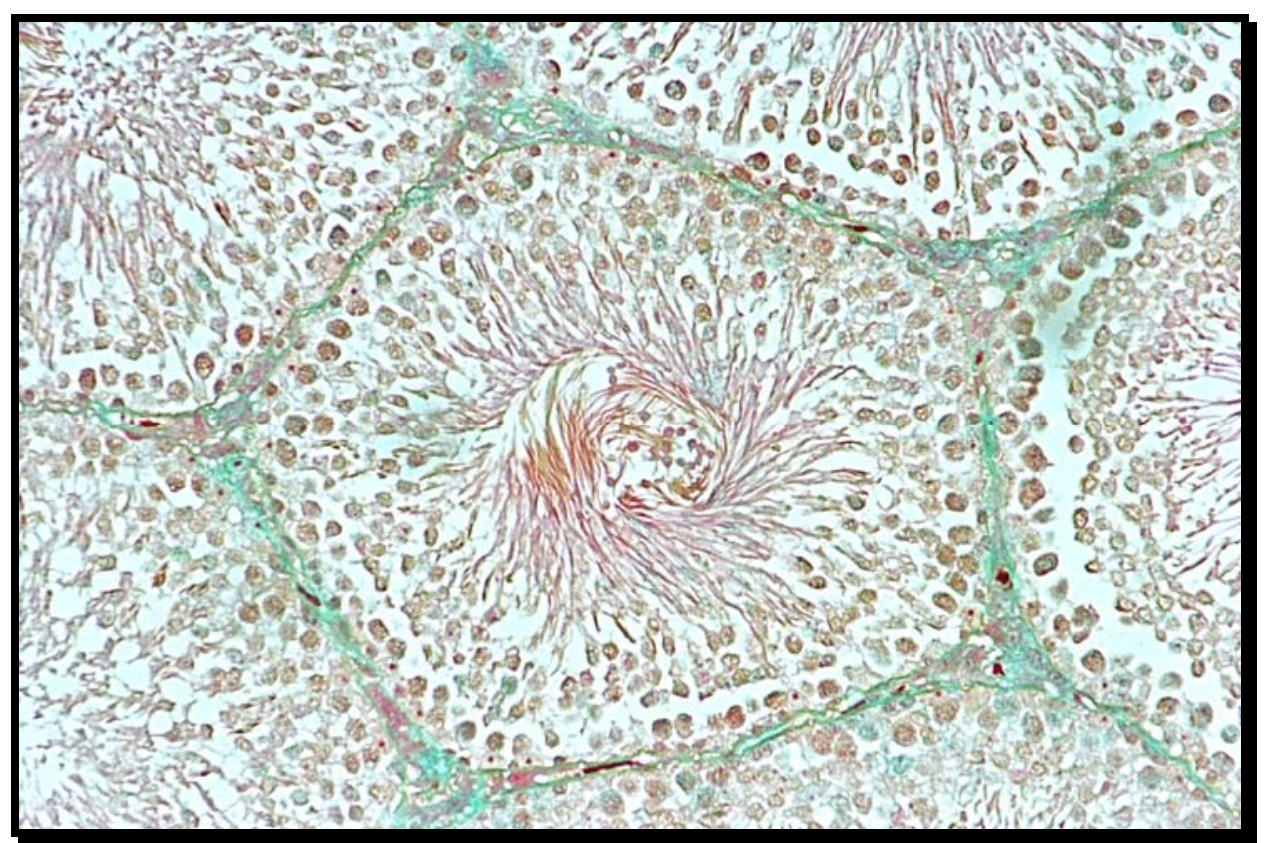

Figura 5 - Túbulo seminífero em fase de pré-espermiação (Tricrômico de Masson - obj. 20x).

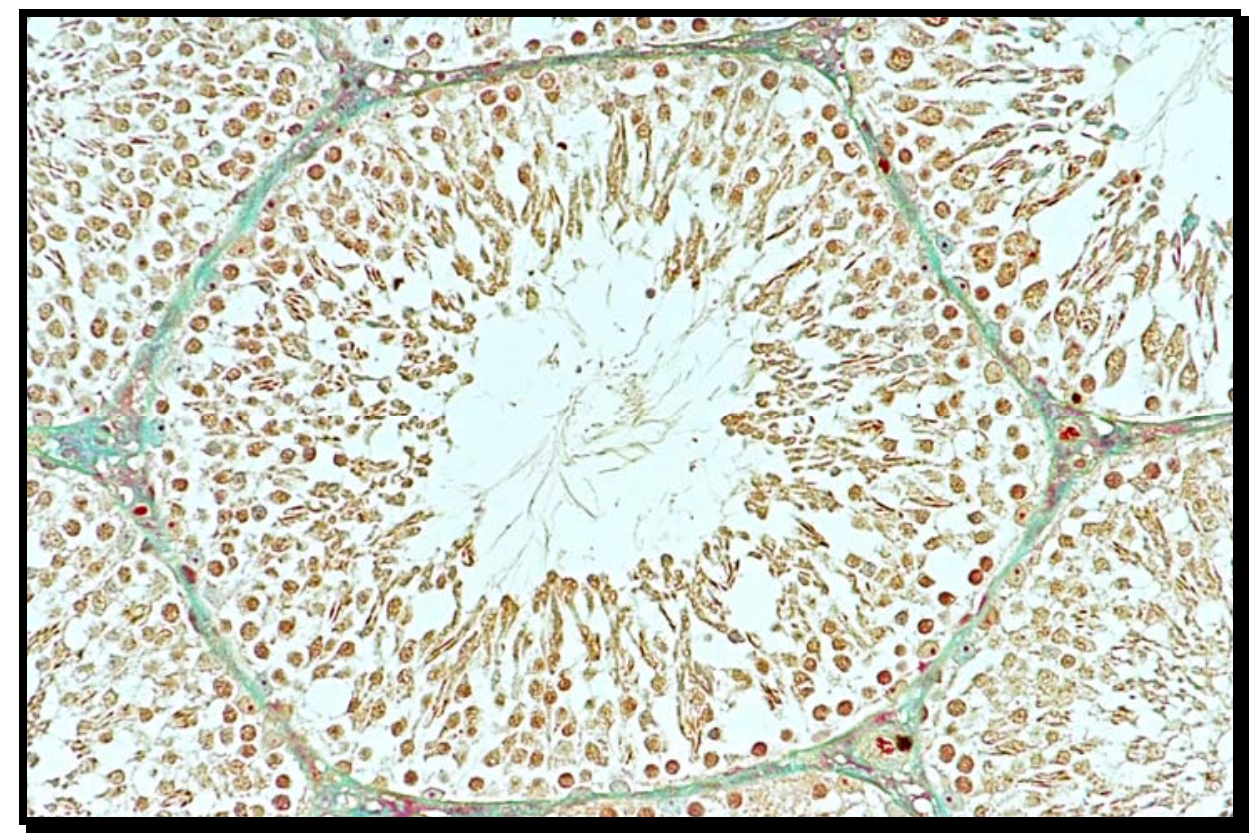

Figura 6 - Túbulo seminífero em fase de pós-espermiação (Tricrômico de Masson - obj. 20x). 


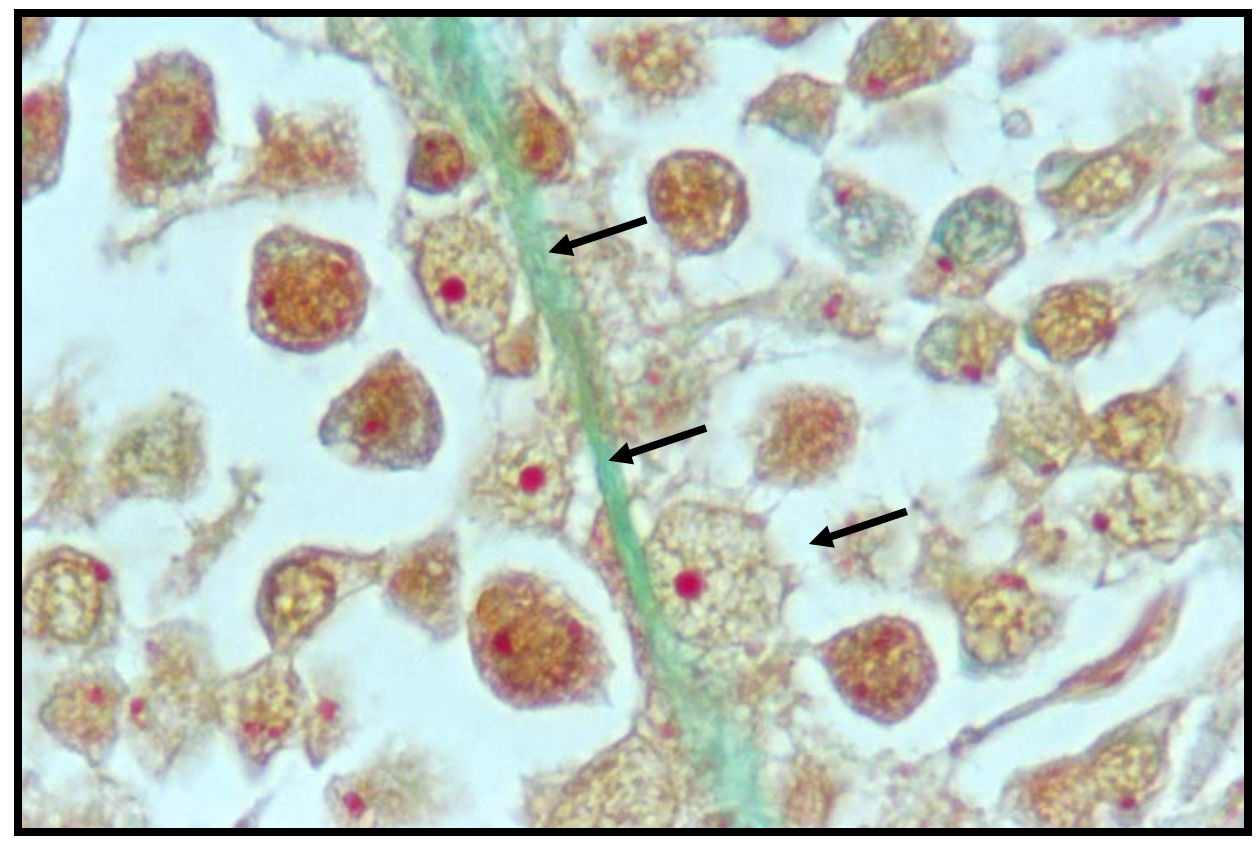

Figura 7: Célula de Sertoli - setas (Tricrômico de Masson - obj. 100x). 


\subsubsection{4 - Próstatas}

Para análise das próstatas os cortes transversais corados em hematoxilina e eosina foram utilizados. Através do microscópio óptico binocular Axioskop 2 Carl Zeiss ${ }^{\circledR}$ com objetiva de imersão de 100x e do programa de análise de imagem $\mathrm{KS} 300^{\circledR} 3.0$ a altura das células epiteliais dos ácinos foram medidas desde sua parte basal até o ápice. Dez ácinos da região distal foram selecionados ao acaso e a altura celular medida em três células por ácino (Figura 8). Posteriormente o mesmo foi realizado nos ácinos da região intermediária (Figura 9), assim como a média da altura celular por região para cada caso. 


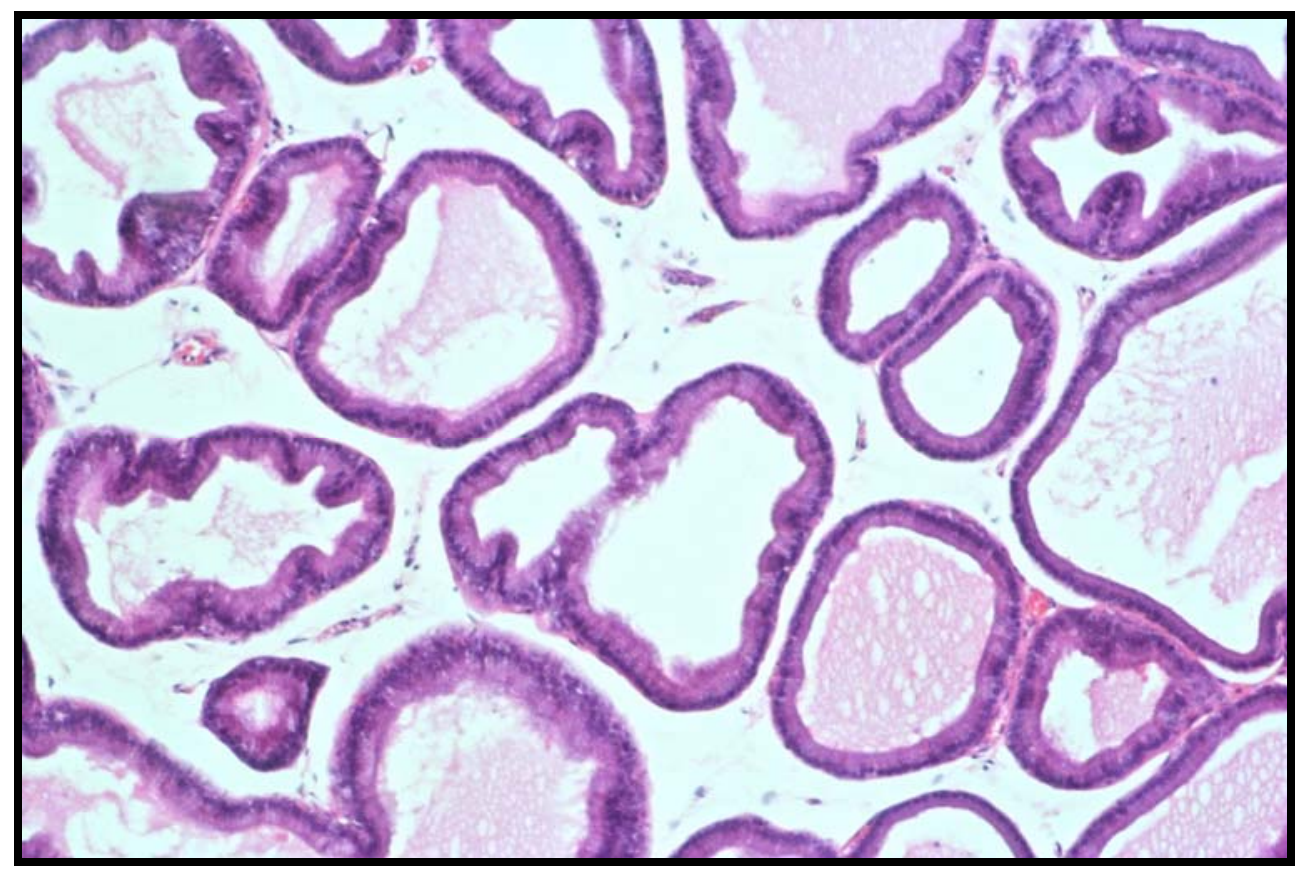

Figura 8 - Ácinos na região distal da próstata (HE - obj. 20x).

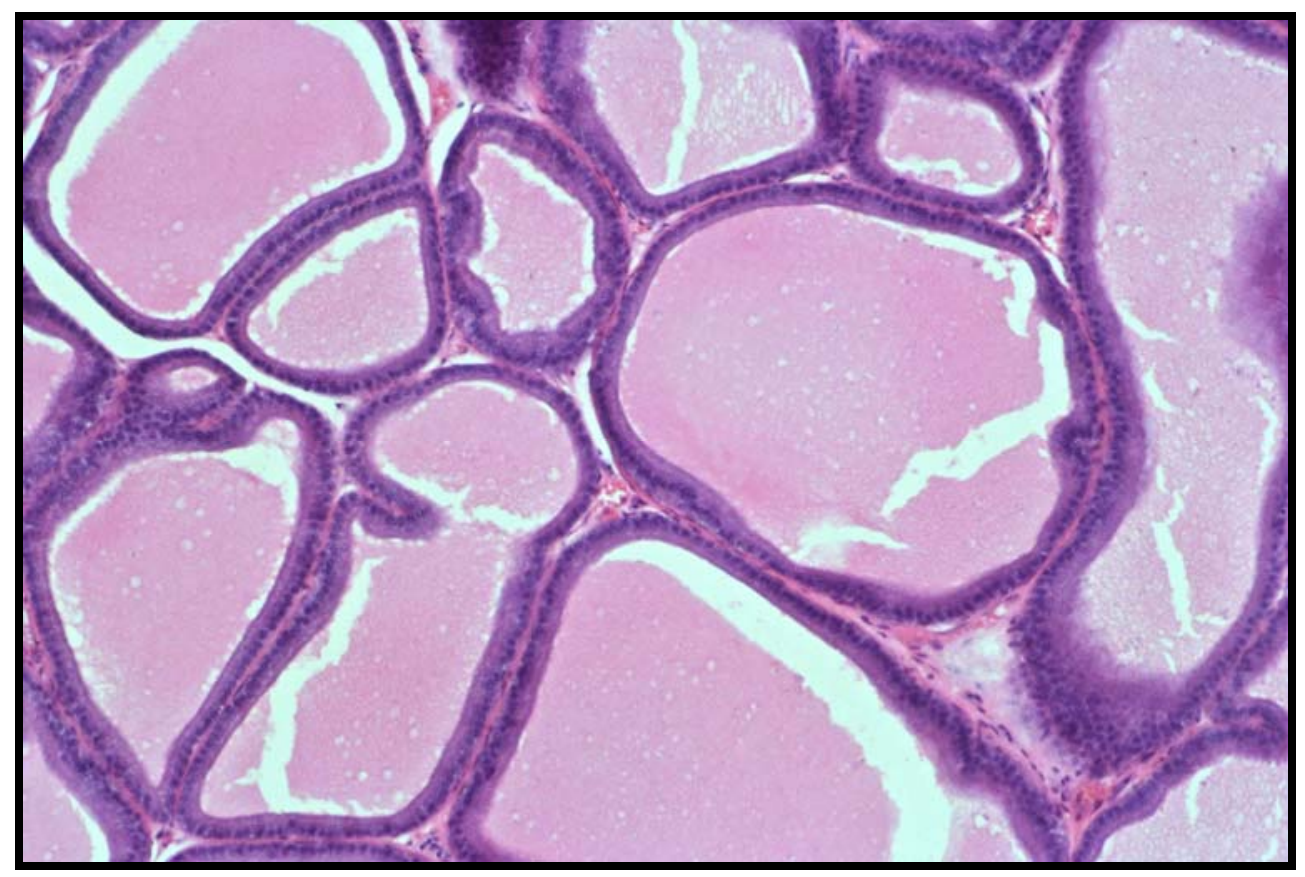

Figura 9 - Ácinos na região intermediária da próstata (HE - obj. 20x). 
5 RESULTADOS 


\section{5 - RESULTADOS}

\section{1 - Análise macroscópica dos órgãos}

\subsection{1 - Úteros}

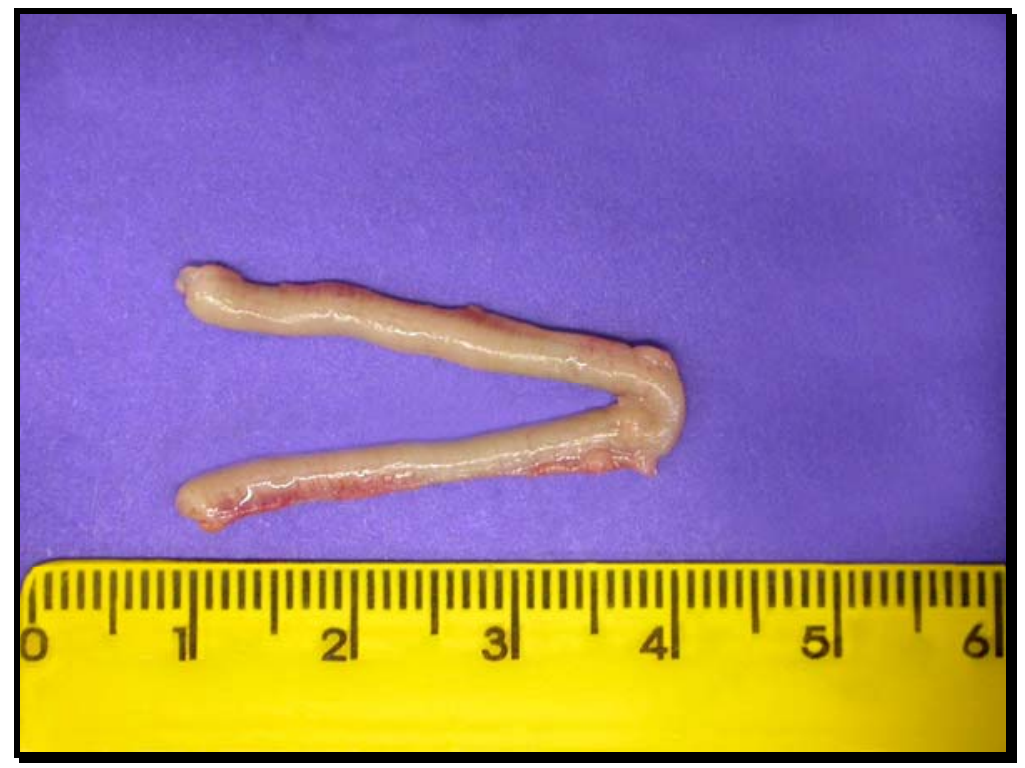

Figura 10 - Útero do grupo controle antes da fixação (fêmea 31).

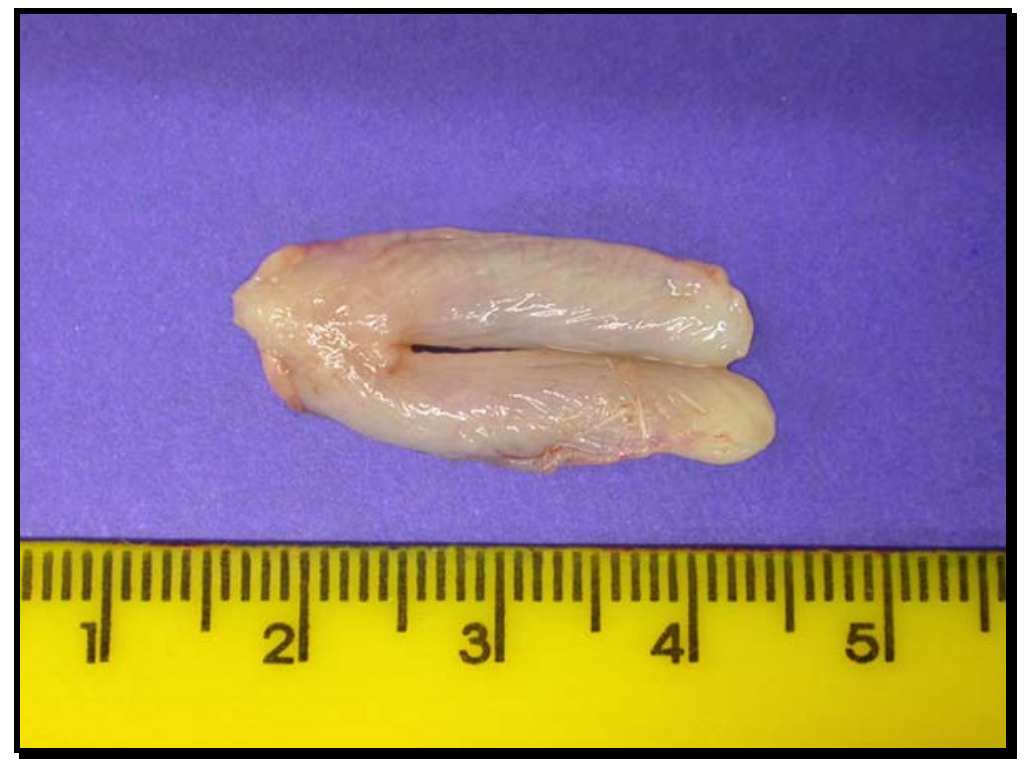

Figura 11 - Útero do grupo experimental antes da fixação (fêmea 15). 


\subsection{2 - Ovários}

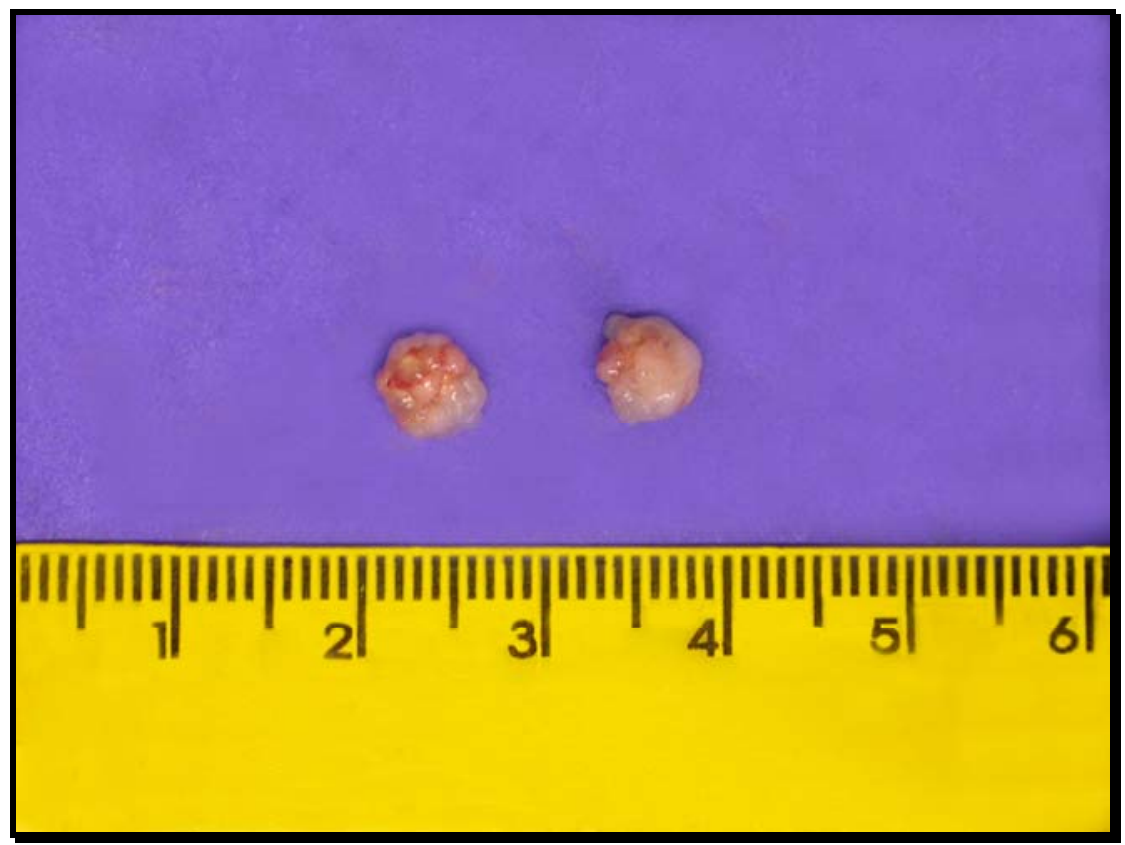

Figura 12 - Ovários do grupo controle antes da fixação (fêmea 30).

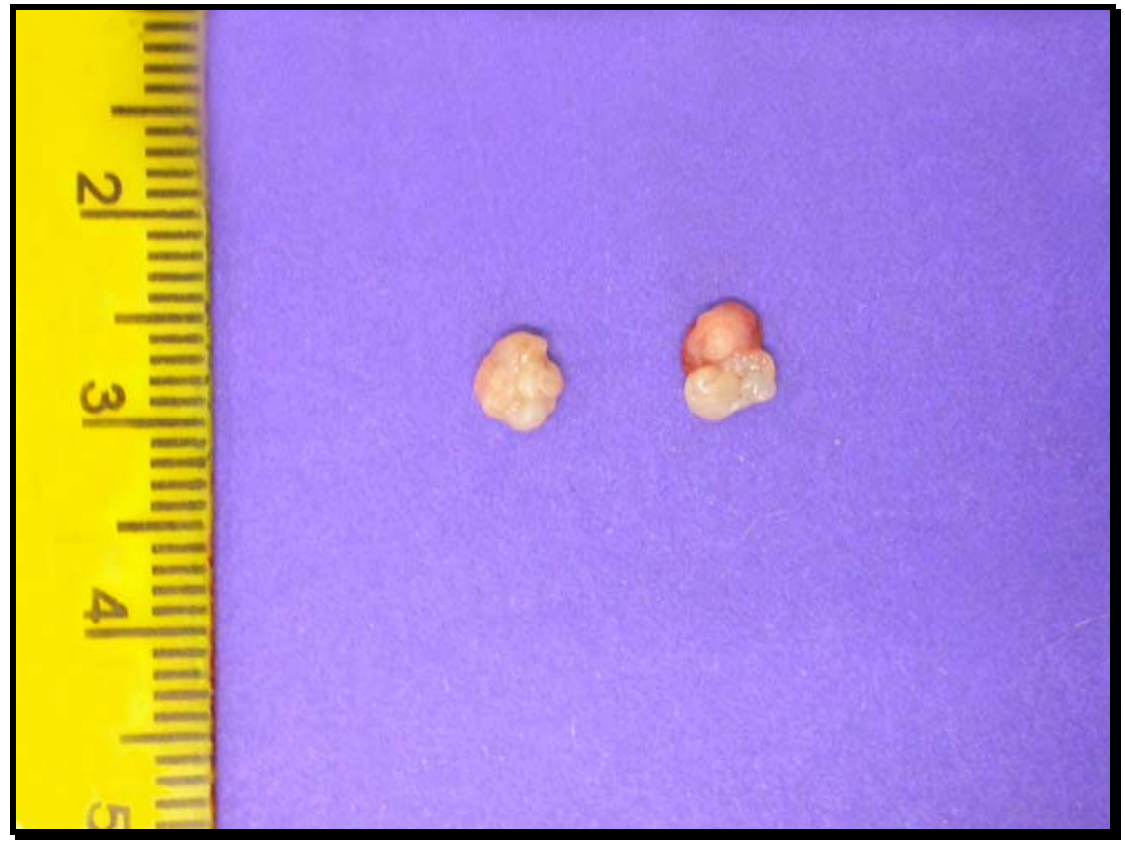

Figura 13 - Ovários do grupo experimental antes da fixação (fêmea 14). 


\subsection{3 - Testículos}

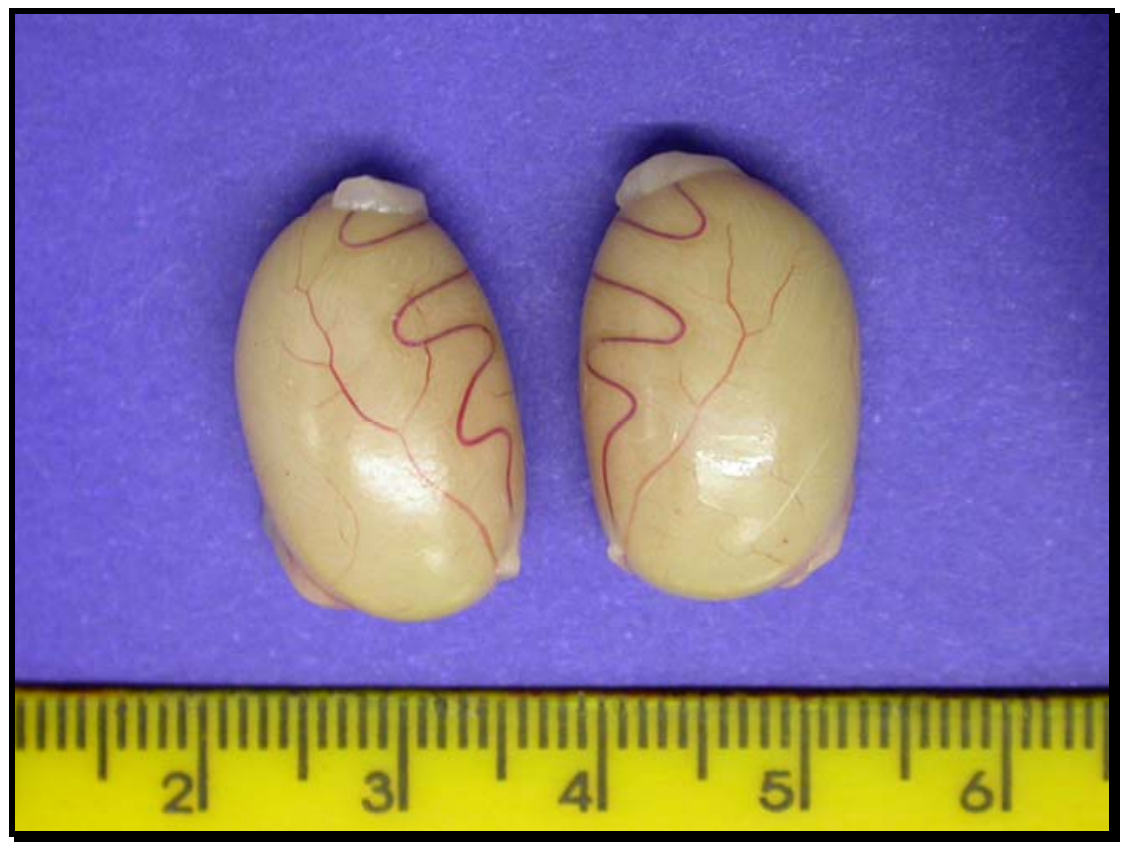

Figura 14 - Testículos do grupo controle antes da fixação (macho 24).

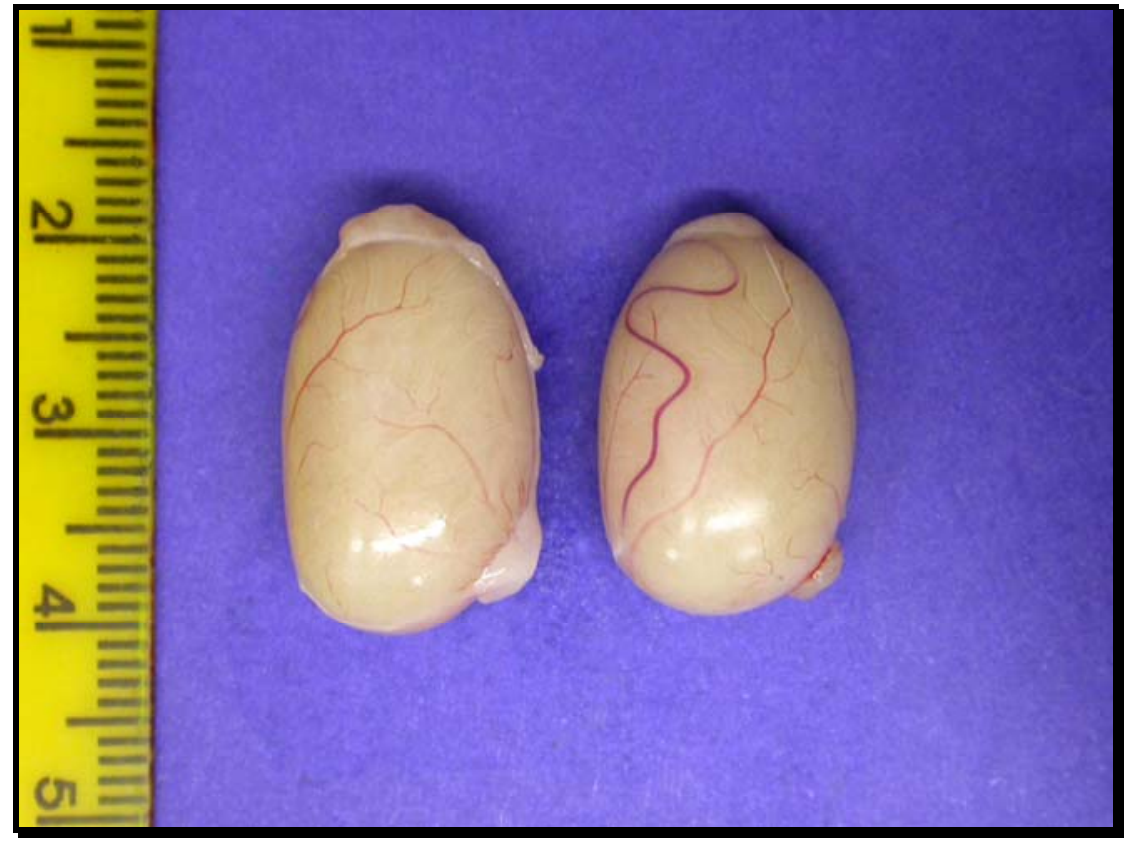

Figura 15 - Testículos do grupo experimental antes da fixação (macho 6). 


\subsection{4 - Próstatas}

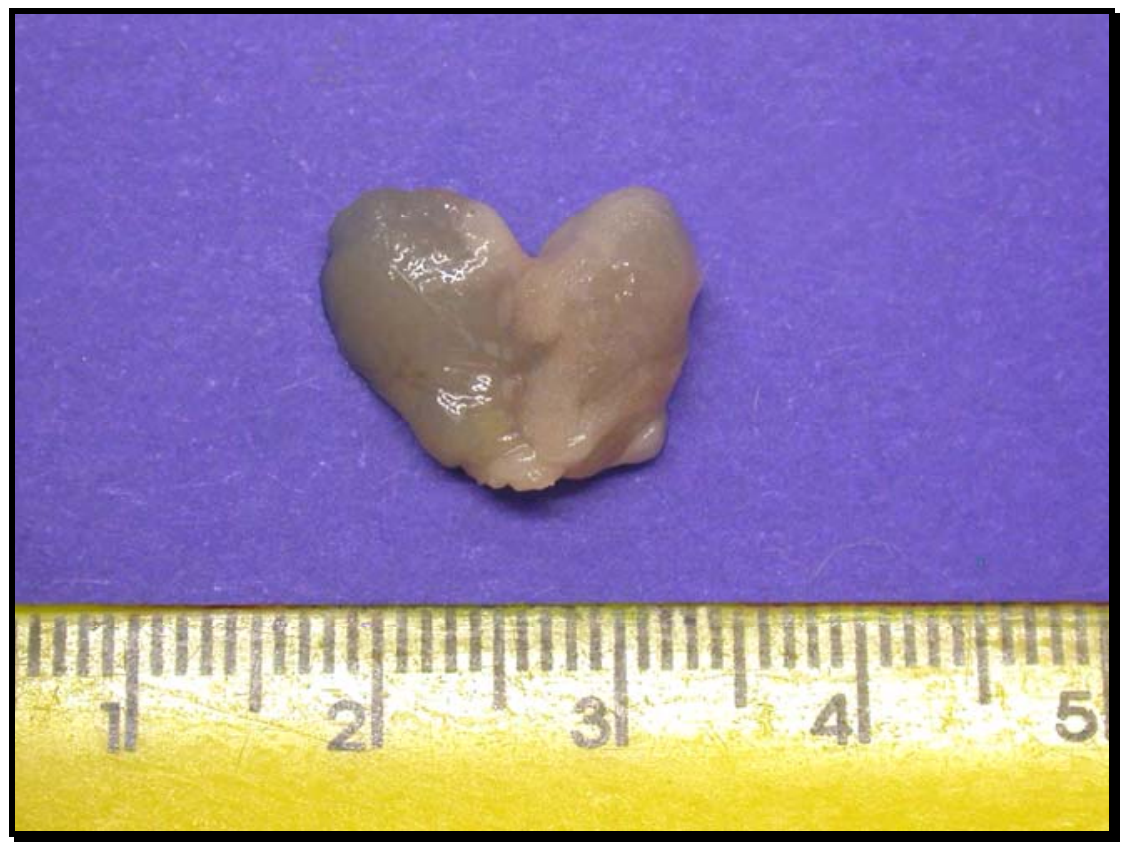

Figura 16 - Próstata do grupo controle antes da fixação (macho 24).

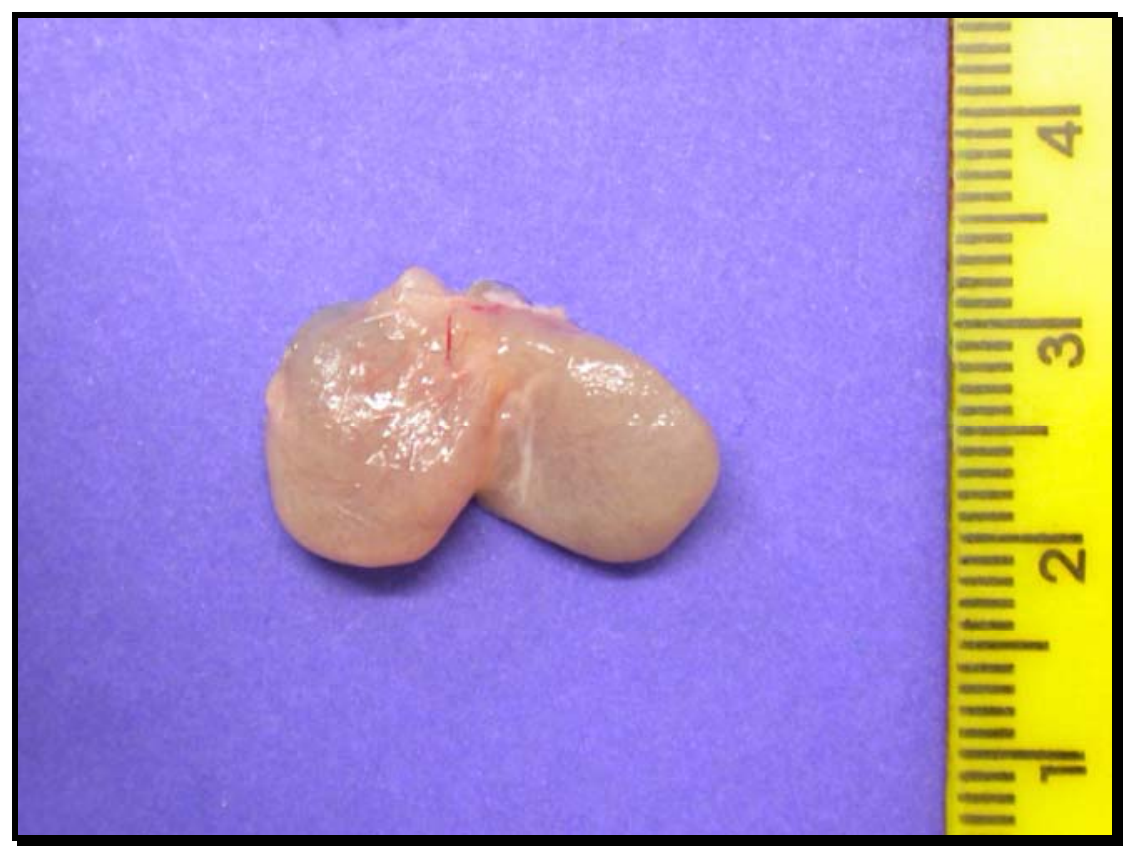

Figura 17 - Próstata do grupo experimental antes da fixação (macho 7). 


\section{2 - Peso geral e dos órgãos dos animais}

\subsection{1 - Peso geral dos animais}

Ao final do experimento observou-se que o grupo controle ganhou mais peso do que o grupo experimental. Os machos do grupo experimental adquiriram, ao final, de $35,68 \%$ a $69,80 \%$ a mais de peso, enquanto os do grupo controle ganharam de 55,31\% a $96,22 \%$ (Tabela 1 ). As fêmeas do grupo experimental adquiriram de $32,74 \%$ a $54,61 \%$ a mais do peso inicial, enquanto as do grupo controle ganharam de $38,36 \%$ a $55,48 \%$ (Tabela 2). Estatisticamente, o ganho de peso entre as fêmeas e os machos do grupo experimental foi significativo, onde $p=0,001$; assim como entre o grupo controle, onde $p=0,000$ (Tabela 3).

A Tabela 4 demonstra que o ganho de peso maior nos machos do grupo controle foi significativo estatisticamente $(p=0,000)$. Embora as fêmeas do grupo controle tenham apresentado um ganho maior do que as do grupo experimental, essa diferença não se apresentou estatisticamente significante $(p=0,525)$. 
Tabela 1 - Peso dos machos no início e ao final do experimento, ganho e percentual de peso.

\begin{tabular}{ccccccc}
\hline Ratos & Gênero & Grupo & $\begin{array}{c}\text { Peso } \\
\text { inicial }(\mathbf{g})\end{array}$ & $\begin{array}{c}\text { Peso } \\
\text { final }(\mathbf{g})\end{array}$ & $\begin{array}{c}\text { Ganho de } \\
\text { peso }(\mathbf{g})\end{array}$ & $\begin{array}{c}\text { Percentual de } \\
\text { ganho (\%) }\end{array}$ \\
\hline 1 & Macho & Exp* $^{*}$ & 227 & 308 & 81 & 35,68 \\
2 & Macho & Exp* $^{*}$ & 215 & 353 & 138 & 64,19 \\
3 & Macho & Exp* $^{*}$ & 202 & 343 & 141 & 69,80 \\
4 & Macho & Exp* $^{*}$ & 215 & 312 & 97 & 45,12 \\
5 & Macho & Exp* $^{*}$ & 211 & 300 & 89 & 42,18 \\
6 & Macho & Exp* & 230 & 344 & 114 & 49,57 \\
7 & Macho & Exp* & 210 & 320 & 110 & 52,38 \\
8 & Macho & Exp* & 213 & 305 & 92 & 43,19 \\
17 & Macho & Controle & 230 & 401 & 171 & 74,35 \\
18 & Macho & Controle & 226 & 351 & 125 & 55,31 \\
19 & Macho & Controle & 220 & 361 & 141 & 64,09 \\
20 & Macho & Controle & 185 & 363 & 178 & 96,22 \\
21 & Macho & Controle & 208 & 364 & 156 & 75,00 \\
22 & Macho & Controle & 251 & 390 & 139 & 55,38 \\
23 & Macho & Controle & 216 & 370 & 154 & 71,30 \\
24 & Macho & Controle & 185 & 351 & 166 & 89,73 \\
\hline
\end{tabular}

* Exp: experimental. 
Tabela 2 - Peso das fêmeas no início e ao final do experimento, ganho e percentual de peso.

\begin{tabular}{ccccccc}
\hline Ratos & Gênero & Grupo & $\begin{array}{c}\text { Peso } \\
\text { inicial } \mathbf{( g )}\end{array}$ & $\begin{array}{c}\text { Peso } \\
\text { final (g) }\end{array}$ & $\begin{array}{c}\text { Ganho de } \\
\text { peso (g) }\end{array}$ & $\begin{array}{c}\text { Percentual de } \\
\text { ganho (\%) }\end{array}$ \\
\hline 9 & Fêmea & Exp* $^{\star}$ & 162 & 236 & 74 & 45,68 \\
10 & Fêmea & Exp* $^{\star}$ & 155 & 239 & 84 & 54,19 \\
11 & Fêmea & Exp $^{\star}$ & 152 & 209 & 57 & 37,50 \\
12 & Fêmea & Exp* $^{\star}$ & 157 & 234 & 77 & 49,04 \\
13 & Fêmea & Exp* $^{\star}$ & 159 & 226 & 67 & 42,14 \\
14 & Fêmea & Exp* & 141 & 218 & 77 & 54,61 \\
15 & Fêmea & Exp* & 149 & 229 & 80 & 53,69 \\
16 & Fêmea & Exp* & 168 & 223 & 55 & 32,74 \\
25 & Fêmea & Controle & 159 & 220 & 61 & 38,36 \\
26 & Fêmea & Controle & 160 & 246 & 86 & 53,75 \\
27 & Fêmea & Controle & 155 & 241 & 86 & 55,48 \\
28 & Fêmea & Controle & 160 & 238 & 78 & 48,75 \\
29 & Fêmea & Controle & 168 & 241 & 73 & 43,45 \\
30 & Fêmea & Controle & 146 & 209 & 63 & 43,15 \\
31 & Fêmea & Controle & 160 & 236 & 76 & 47,50 \\
32 & Fêmea & Controle & 158 & 232 & 74 & 46,84 \\
\hline
\end{tabular}

\footnotetext{
* Exp: experimental.
} 


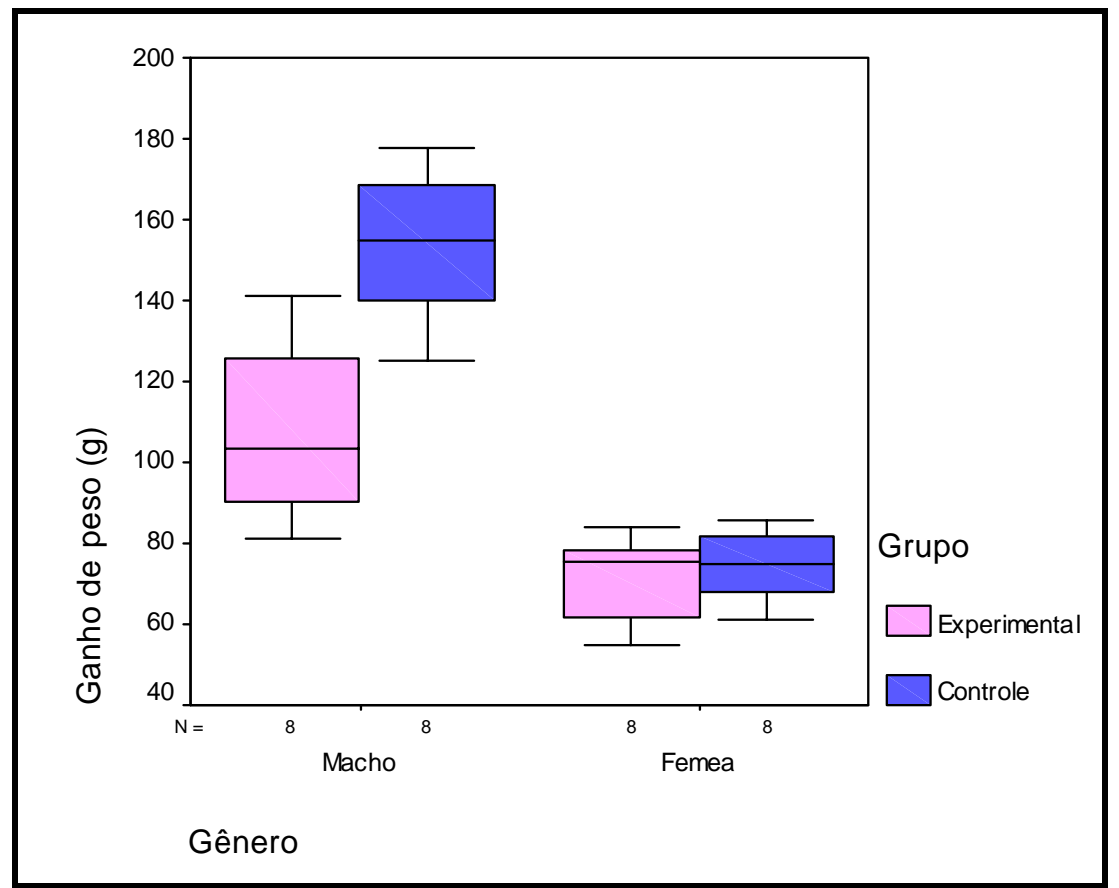

Gráfico 1 - Diferença do ganho de peso entre machos e fêmeas, do grupo experimental e controle.

Tabela 3 - Análise estatística da diferença de ganho de peso entre fêmeas e machos do grupo experimental; e fêmeas e machos do grupo controle.

\begin{tabular}{ccccccc}
\hline Medida & \multicolumn{2}{c}{$\begin{array}{c}\text { Fêmea } \\
\text { Média / dp }\end{array}$} & \multicolumn{2}{c}{$\begin{array}{c}\text { Macho } \\
\text { Média / dp }\end{array}$} & t & p \\
\hline $\begin{array}{l}\text { Ganho Peso } \\
\text { experimental }\end{array}$ & 71,38 & 10,68 & 107,75 & 22,35 & 4,154 & $0,001^{*}$ \\
$\begin{array}{c}\text { Ganho Peso } \\
\text { controle }\end{array}$ & 74,63 & 9,23 & 153,75 & 17,92 & 11,104 & $0,000^{*}$ \\
\hline * diferença estatística significante $(\mathbf{p}<0,05)$ & & & &
\end{tabular}

* diferença estatística significante $(p<0,05)$. 
Tabela 4 - Análise estatística da diferença de peso adquirido entre o grupo experimental e controle, nos diferentes gêneros.

\begin{tabular}{ccccccc}
\hline Medida & \multicolumn{2}{c}{$\begin{array}{c}\text { Experimental } \\
\text { Média / dp }\end{array}$} & \multicolumn{2}{c}{$\begin{array}{c}\text { Controle } \\
\text { Média / dp }\end{array}$} & $\mathbf{t}$ & $\mathbf{p}$ \\
\hline $\begin{array}{c}\text { Ganho Peso } \\
\text { Machos }\end{array}$ & 107,75 & 22,35 & 153,75 & 17,92 & $-4,542$ & $0,000^{*}$ \\
$\begin{array}{c}\text { Ganho Peso } \\
\text { Fêmeas }\end{array}$ & 71,38 & 10,68 & 74,63 & 9,23 & $-0,651$ & $0,525^{\text {ns }}$ \\
\hline $\begin{array}{c}\text { * diferença estatística significante }(\mathbf{p}<0,05) . \\
\text { ns diferença estatística não significante. }\end{array}$ & & & & & \\
\end{tabular}




\subsection{2 - Peso dos órgãos masculinos}

O peso dos testículos ao final do experimento do grupo experimental variou de 2,52g a 2,92g e os do grupo controle, de 2,76g a 3,18g. Nas próstatas a variação de peso foi de $0,65 \mathrm{~g}$ a $0,93 \mathrm{~g}$ e $0,35 \mathrm{~g}$ a $0,78 \mathrm{~g}$ para o grupo experimental e controle, respectivamente (Tabela 5).

As diferenças de peso dos testículos e próstatas entre os grupos experimental e controle foram estatisticamente significante, onde $p=0,006$ e $p=0,001$, respectivamente (Tabela 6).

Tabela 5 - Peso dos testículos e próstatas do grupo experimental e controle ao final do experimento.

\begin{tabular}{cccc}
\hline Ratos & Grupo & Testículos $(\mathbf{g})$ & Próstatas $(\mathbf{g})$ \\
\hline 1 & Exp* $^{\star}$ & 2,92 & 0,69 \\
2 & Exp* $^{\star}$ & 2,68 & 0,65 \\
3 & Exp $^{\star}$ & 2,9 & 0,73 \\
4 & Exp* $^{\star}$ & 2.63 & 0,68 \\
5 & Exp* $^{\star}$ & 2,52 & 0,93 \\
6 & Exp* & 2,8 & 0,81 \\
7 & Exp* & 2,66 & 0,92 \\
8 & Exp* & 2,56 & 0,68 \\
17 & Controle & 2,79 & 0,45 \\
18 & Controle & 3,01 & 0,35 \\
19 & Controle & 3,1 & 0,51 \\
20 & Controle & 3,18 & 0,42 \\
21 & Controle & 2,85 & 0,5 \\
22 & Controle & 2,9 & 0,6 \\
23 & Controle & 2,76 & 0,78 \\
24 & Controle & 3,08 & 0,5 \\
\hline
\end{tabular}

* Exp: experimental. 


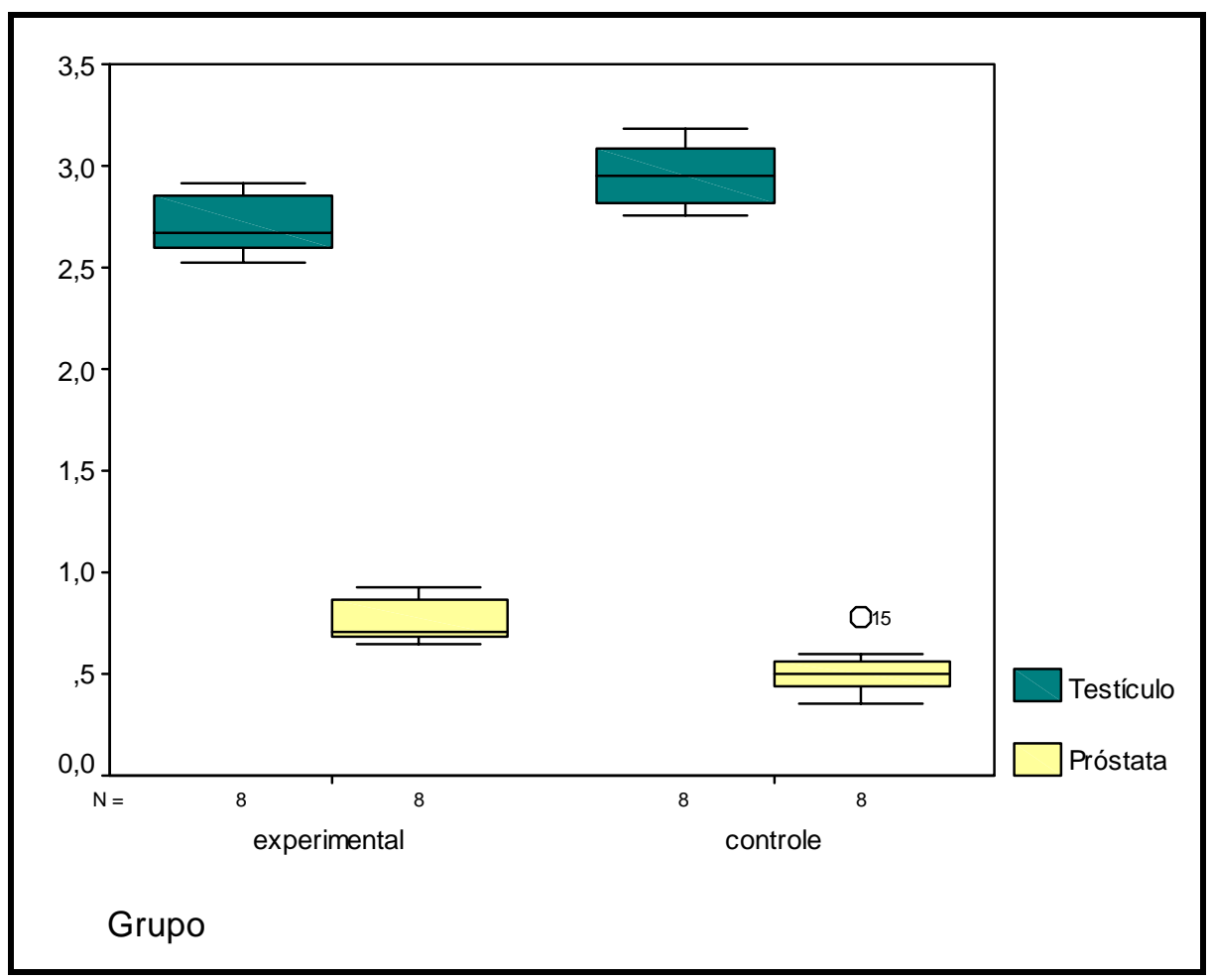

Gráfico 2 - Diferença de peso dos testículos e próstatas entre o grupo experimental e controle.

Tabela 6 - Análise estatística da diferença de peso dos testículos e próstatas entre o grupo experimental e controle.

\begin{tabular}{ccccccc}
\hline Medida & \multicolumn{2}{c}{$\begin{array}{c}\text { Experimental } \\
\text { Média / dp }\end{array}$} & \multicolumn{2}{c}{$\begin{array}{c}\text { Controle } \\
\text { Média / dp }\end{array}$} & t & p \\
\hline Peso testículo & 2,708 & 0,1496 & 2,958 & 0,1556 & $-3,276$ & $0,006^{*}$ \\
& & & & & & \\
Peso próstata & 0,761 & 0,1119 & 0,513 & 0,1300 & 4,080 & $0,001^{*}$ \\
\hline * diferença estatística significante $(\mathrm{p}<0,05)$. & & &
\end{tabular}

* diferença estatística significante $(p<0,05)$. 


\subsection{3 - Peso dos órgãos femininos}

A variação de peso dos ovários no grupo experimental ocorreu entre 0,06g e 0,11g, enquanto no grupo controle observou-se variação entre 0,09g e $0,15 \mathrm{~g}$. Para os úteros detectou-se variação entre $0,57 \mathrm{~g}$ e 0,72 , para o experimental; e 0,32g e 0,5, para o controle (Tabela 7).

A análise estatística da diferença de peso dos ovários e úteros do grupo experimental e controle revelou significância, onde $p=0,005$ e $p=0,000$, respectivamente.

Tabela 7 - Peso dos ovários e úteros do grupo experimental e controle ao final do experimento.

\begin{tabular}{|c|c|c|c|}
\hline Ratas & Grupo & Ovários (g) & Úteros $(\mathbf{g})$ \\
\hline 9 & Exp* & 0,11 & 0.72 \\
\hline 10 & Exp* & 0,1 & 0,57 \\
\hline 11 & Exp* & 0,07 & 0,63 \\
\hline 12 & Exp* & 0,08 & 0,64 \\
\hline 13 & Exp $^{*}$ & 0,07 & 0,68 \\
\hline 14 & $\operatorname{Exp}^{*}$ & 0,06 & 0,63 \\
\hline 15 & Exp* & 0,08 & 0,71 \\
\hline 16 & Exp* & 0,06 & 0,71 \\
\hline 25 & Controle & 0,09 & 0,35 \\
\hline 26 & Controle & 0,15 & 0,32 \\
\hline 27 & Controle & 0,1 & 0,36 \\
\hline 28 & Controle & 0,11 & 0,32 \\
\hline 29 & Controle & 0,11 & 0,39 \\
\hline 30 & Controle & 0,12 & 0,5 \\
\hline 31 & Controle & 0,11 & 0,33 \\
\hline 32 & Controle & 0,09 & 0,49 \\
\hline
\end{tabular}

* Exp: experimental. 


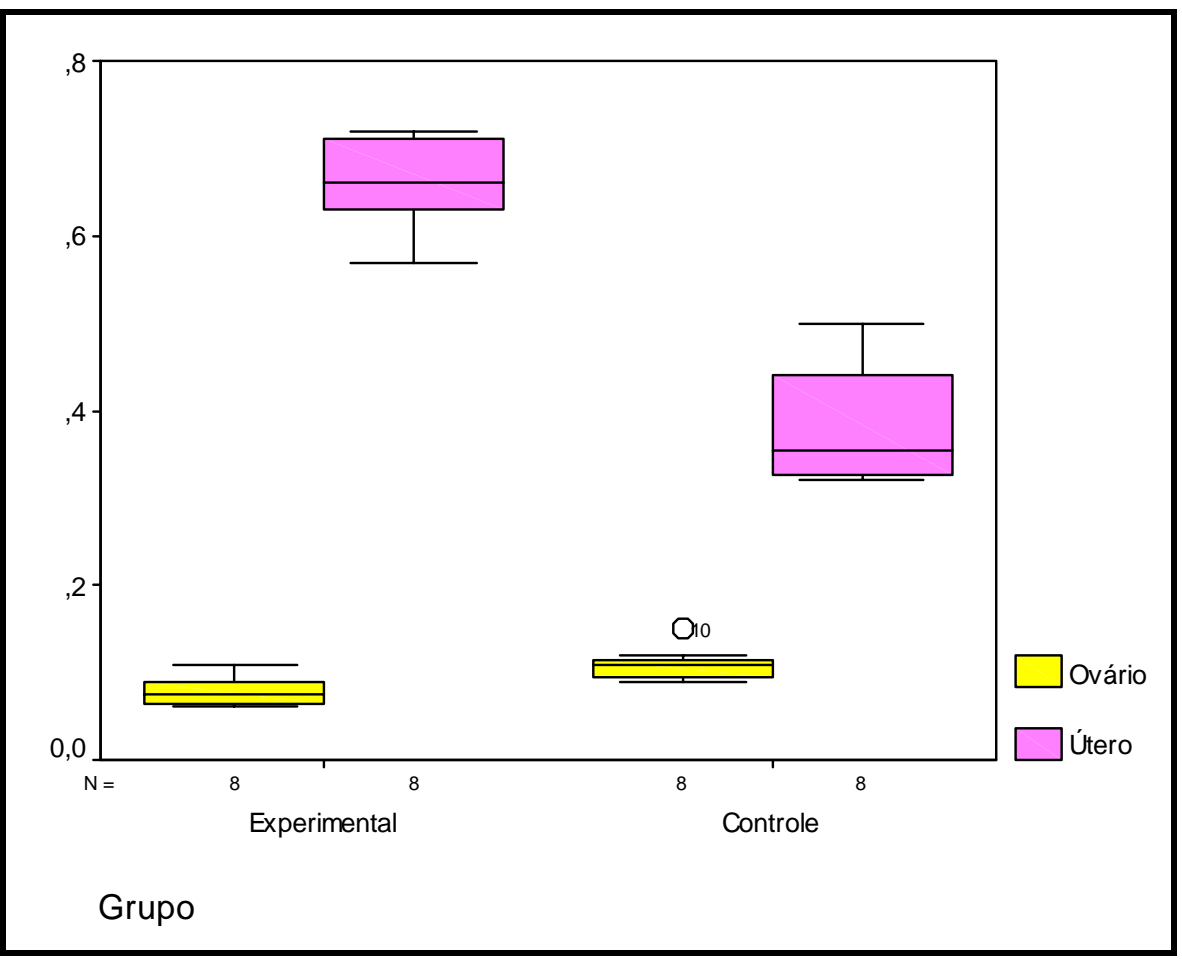

Gráfico 3 - Diferença de peso dos ovários e úteros entre o grupo experimental e controle.

Tabela 8 - Análise estatística da diferença de peso dos ovários e úteros entre o grupo experimental e controle.

\begin{tabular}{llllllc}
\hline Medida & \multicolumn{2}{c}{$\begin{array}{c}\text { Experimental } \\
\text { Média } / \mathbf{d p}\end{array}$} & \multicolumn{2}{c}{$\begin{array}{c}\text { Controle } \\
\text { Média } / \mathbf{d p}\end{array}$} & $\mathbf{t}$ & $\mathbf{p}$ \\
\hline Peso ovário & 0,079 & 0,018 & 0,110 & 0,019 & $-3,345$ & $0,005^{*}$ \\
& & & & & & \\
Peso útero & 0,661 & 0,052 & 0,382 & 0,073 & 8,750 & $0,000^{*}$ \\
\hline * diferença estatística significante $(p<0,05)$.
\end{tabular}




\section{3 - Análise morfométrica}

\subsection{1 - Área e espessura do miométrio e endométrio}

A área do miométrio no grupo experimental apresentou-se maior do que a do grupo controle, sendo a diferença, entre os grupos, estatisticamente significativa $(p=0,000)$. Embora a área do endométrio tenha apresentado diferença entre os grupos, sendo maior nas ratas tratadas, estatisticamente não se detectou significância $(p=0,126)$.

Com relação à espessura, foi possível observar resultado semelhante aquele observado para as áreas. As espessuras do miométrio e endométrio apresentam-se maiores no grupo experimental, sendo a diferença estatística significativa apenas para o miométrio $(p=0,000)$. 
Tabela 9 - Medidas da área e espessura do endométrio e miométrio para o grupo experimental e controle.

\begin{tabular}{cccccc}
\hline Ratas & Grupo & $\begin{array}{c}\text { Miométrio } \\
\text { Área } \boldsymbol{\mu m}^{2}\end{array}$ & $\begin{array}{c}\text { Endométrio } \\
\text { Área } \boldsymbol{\mu m}^{2}\end{array}$ & $\begin{array}{c}\text { Miométrio } \\
\text { Espessura } \mu \mathrm{m}\end{array}$ & $\begin{array}{c}\text { Endométrio } \\
\text { Espessura } \boldsymbol{\mu m}\end{array}$ \\
\hline 9 & Exp* $^{*}$ & 6,134 & 2,864 & 710,61 & 582,09 \\
10 & Exp $^{\star}$ & 6,919 & 3,155 & 693,76 & 480,21 \\
11 & Exp* $^{\star}$ & 6,782 & 2,081 & 763,78 & 414,56 \\
12 & Exp* & 7,333 & 2,935 & 808,83 & 528,47 \\
13 & Exp* & 5,953 & 2,391 & 725,48 & 429,82 \\
14 & Exp* & 6,884 & 2,028 & 874,05 & 393,92 \\
15 & Exp* & 6,837 & 2,283 & 768,35 & 481,52 \\
16 & Exp* & 7,247 & 3,296 & 786,73 & 604,78 \\
25 & Controle & 2,699 & 1,951 & 408,77 & 490,56 \\
26 & Controle & 2,776 & 2,233 & 352,36 & 504,92 \\
27 & Controle & 3,136 & 2,17 & 478,02 & 483,22 \\
28 & Controle & 2,563 & 1,993 & 380,08 & 513 \\
29 & Controle & 2,193 & 1,493 & 356,72 & 342,53 \\
30 & Controle & 4,342 & 3,345 & 495,75 & 534,95 \\
31 & Controle & 2,585 & 1,846 & 399,92 & 431,66 \\
32 & Controle & 3,605 & 2,569 & 545,08 & 514,96 \\
\hline
\end{tabular}

* Exp: experimental. 


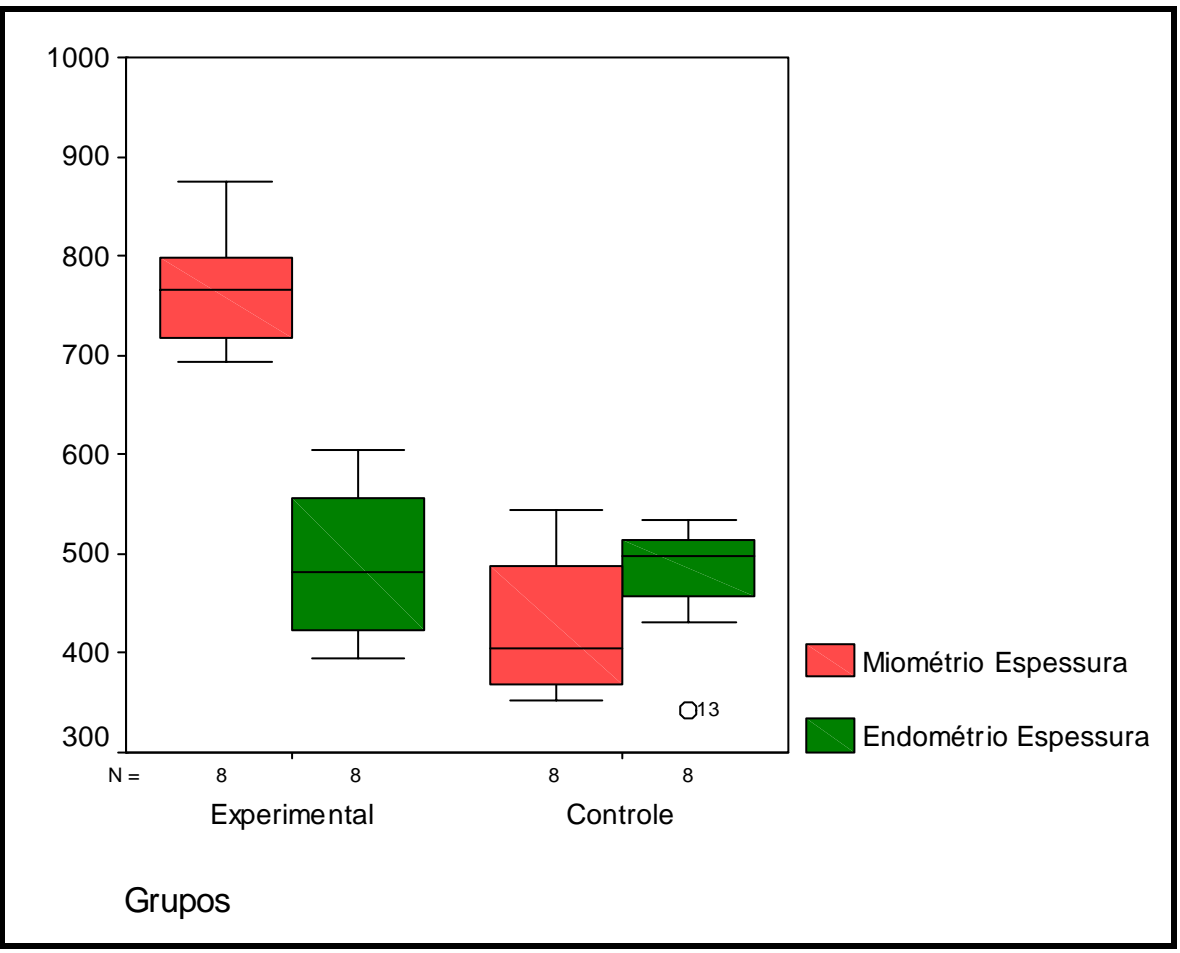

Gráfico 4 - Diferença da espessura do miométrio e endométrio entre o grupo experimental e controle.

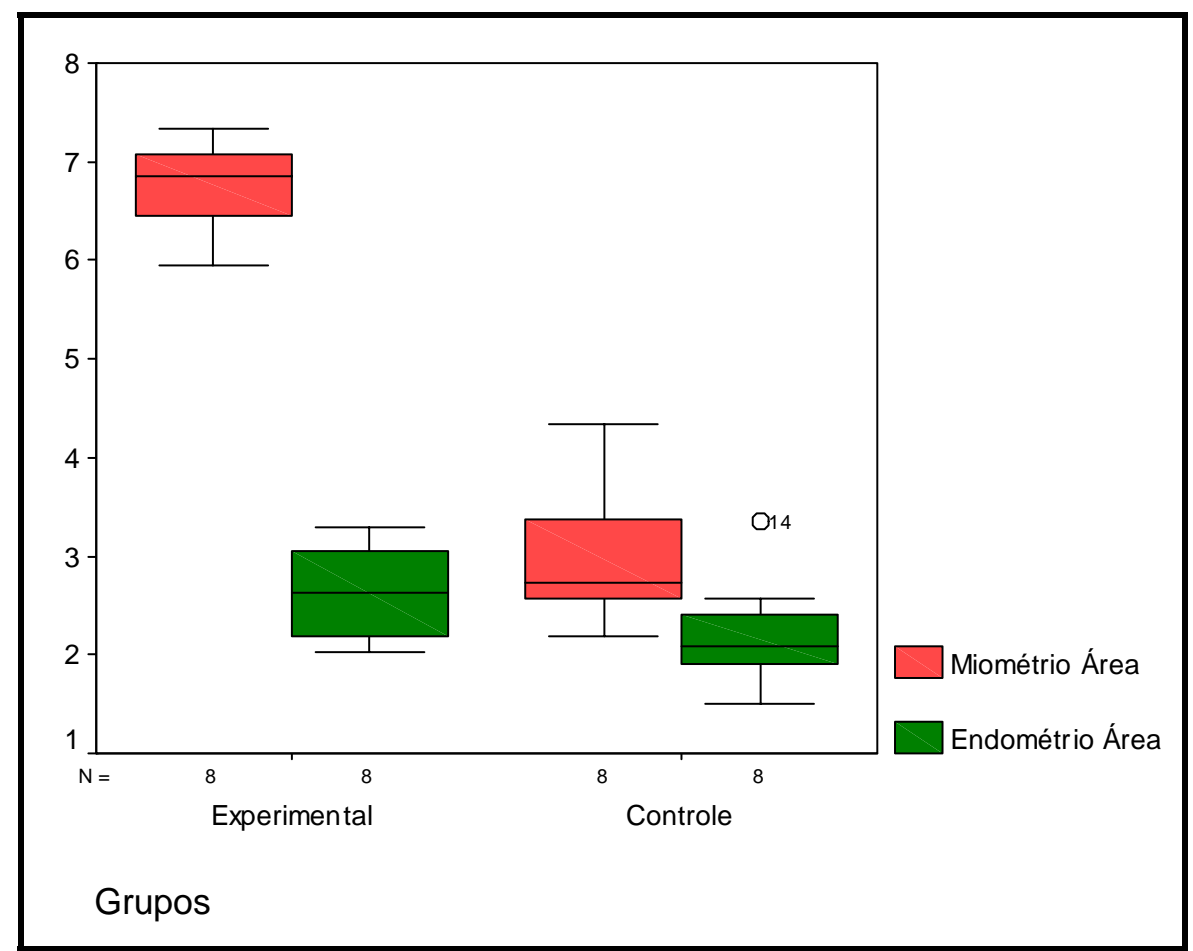

Gráfico 5 - Diferença da área do miométrio e endométrio entre o grupo experimental e controle. 
Tabela 10 - Análise estatística da diferença da área e espessura no endométrio e miométrio entre os grupos experimental e controle.

\begin{tabular}{ccccccc}
\hline Medida & \multicolumn{2}{c}{$\begin{array}{c}\text { Experimental } \\
\text { Média / dp }\end{array}$} & \multicolumn{2}{c}{$\begin{array}{c}\text { Controle } \\
\text { Média / dp }\end{array}$} & $\mathbf{t}$ & $\mathbf{p}$ \\
\hline $\begin{array}{c}\text { Miométrio } \\
\text { área }\end{array}$ & 6,76 & 0,49 & 2,99 & 0,69 & 12,636 & $0,000^{*}$ \\
$\begin{array}{c}\text { Miométrio } \\
\text { espessura }\end{array}$ & 766,45 & 58,40 & 427,09 & 70,76 & 10,462 & $0,000^{*}$ \\
$\begin{array}{c}\text { Endométrio } \\
\text { área }\end{array}$ & 2,63 & 0,49 & 2,20 & 0,56 & 1,629 & $0,126^{\text {ns }}$ \\
$\begin{array}{c}\text { Endométrio } \\
\text { espessura }\end{array}$ & 489,42 & 77,31 & 476,97 & 62,37 & 0,354 & $0,728^{\text {ns }}$ \\
\hline
\end{tabular}

* diferença estatística significante $(p<0,05)$.

${ }^{\text {ns }}$ diferença estatística não significante. 


\subsection{2 - Contagem das células de Sertoli nos testículos}

A média do número de células de Sertoli dos túbulos seminíferos em fase pós-espermiação no grupo experimental mostrou-se ligeiramente mais elevada do que nos túbulos em pré-espermiação, não apresentando significância estatística. $O$ mesmo foi observado no grupo controle, porém com diferença estatística significante entre os túbulos em pré-espermiação e pós-espermiação (Tabela 12).

A comparação do número de células de Sertoli nos túbulos em préespermiação e pós-espermiação entre os grupos experimental e controle, observouse menor número no grupo controle para as duas fases, porém sem diferença estatística significativa (Tabela 13). 
Tabela 11: Soma do número de células de Sertoli em 10 túbulos seminíferos na fase pré-espermiação e em 10 túbulos na pós-espermiação.

\begin{tabular}{cccc}
\hline Ratos & Grupo & Pré-espermiação & Pós-espermiação \\
\hline 1 & Exp* $^{*}$ & 455 & 422 \\
2 & Exp* $^{*}$ & 472 & 510 \\
3 & Exp* $^{*}$ & 426 & 404 \\
4 & Exp* $^{*}$ & 440 & 459 \\
5 & Exp* & 453 & 426 \\
6 & Exp* & 440 & 451 \\
7 & Exp* & 394 & 451 \\
8 & Exp* & 479 & 519 \\
17 & Controle & 406 & 430 \\
18 & Controle & 426 & 431 \\
19 & Controle & 465 & 472 \\
20 & Controle & 424 & 417 \\
21 & Controle & 319 & 349 \\
22 & Controle & 390 & 413 \\
23 & Controle & 329 & 379 \\
24 & Controle & 414 & 418 \\
\hline *Exp: experimental & &
\end{tabular}

* Exp: experimental 


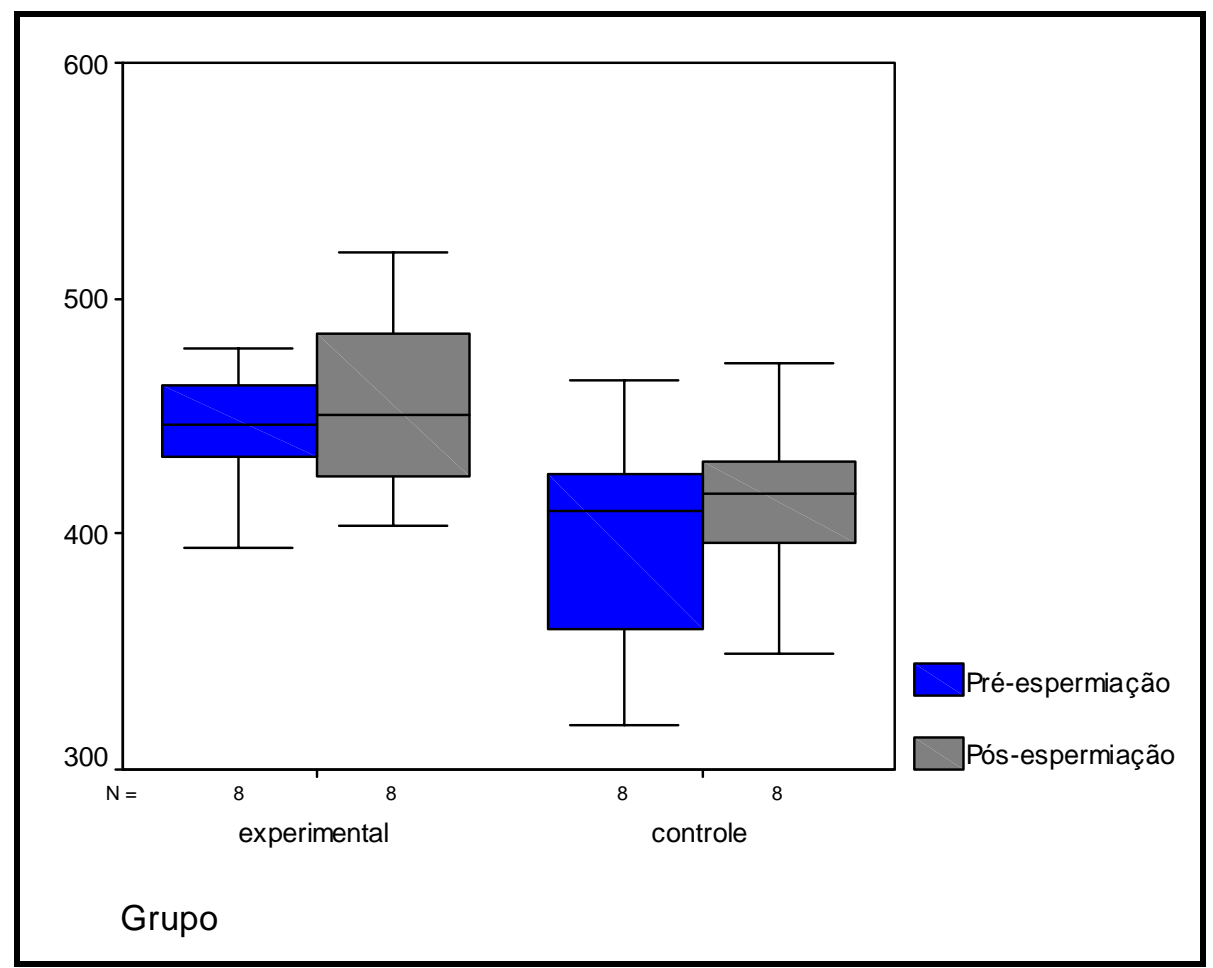

Gráfico 6 - Diferença do números de células de Sertoli nos túbulos em fase de pré-espermiação e pós-espermiação nos grupos experimental e controle.

Tabela 12 - Análise estatística da diferença no número de células de Sertoli entre os túbulos em fase de pré-espermiação e pós-espermiação nos grupos experimental e controle.

\begin{tabular}{ccccccc}
\hline Medida & \multicolumn{2}{c}{$\begin{array}{c}\text { Pré-espermiação } \\
\text { Média / dp }\end{array}$} & \multicolumn{2}{c}{$\begin{array}{c}\text { Pós-espermiação } \\
\text { Média / dp }\end{array}$} & t & p \\
\hline Experimental & 444,87 & 26,88 & 455,25 & 40,88 & $-0,857$ & $0,420^{\text {ns }}$ \\
Controle & 396,62 & 49,74 & 413,62 & 36,61 & $-2,634$ & $0,034^{*}$ \\
\hline
\end{tabular}

* diferença estatística significante $(p<0,05)$.

${ }^{\text {ns }}$ diferença estatística não significante. 
Tabela 13 - Análise estatística da diferença no número de células de Sertoli entre os grupos experimental e controle nos túbulos em fase de pré-espermiação e pós-espermiação.

\begin{tabular}{ccccccc}
\hline Medida & \multicolumn{2}{c}{$\begin{array}{c}\text { Experimental } \\
\text { Média / dp }\end{array}$} & \multicolumn{2}{c}{$\begin{array}{c}\text { Controle } \\
\text { Média / dp }\end{array}$} & t & p \\
\hline Pré-espermiação & 444,87 & 26,88 & 396,62 & 49,74 & 2,414 & $0,30^{\text {ns }}$ \\
& & & & & & \\
Pós-espermiação & 455,25 & 40,88 & 413,62 & 36,61 & 2,145 & $0,50^{\text {ns }}$ \\
\hline \multicolumn{2}{c}{ ns diferença estatística não significante. }
\end{tabular}

${ }^{\text {ns }}$ diferença estatística não significante. 


\subsection{3 - Altura das células do epitélio glandular nas próstatas}

A média das alturas das células do epitélio glandular da região distal e intermediária apresentou-se maiores no grupo experimental do que no controle, porém não foi possível observar significância estatística em nenhuma região.

Tabela 14 - Média das alturas celulares das glândulas da região distal e intermediária.

\begin{tabular}{cccc}
\hline Ratos & Grupo & \multicolumn{2}{c}{ Média da Altura Celular $(\boldsymbol{\mu m})$} \\
& & Região Distal & Região Intermediária \\
\hline 1 & Exp* $^{*}$ & 23,73 & 19,66 \\
2 & Exp* $^{*}$ & 22,15 & 21,05 \\
3 & Exp* $^{*}$ & 21,43 & 15,45 \\
4 & Exp* $^{*}$ & 18,13 & 15,45 \\
5 & Exp* & 24,59 & 18,72 \\
6 & Exp* & 16,3 & 19,07 \\
7 & Exp* & 24,1 & 18,27 \\
8 & Exp* & 19,1 & 18,65 \\
17 & controle & 21,39 & 21,23 \\
18 & controle & 15,54 & 14,38 \\
19 & controle & 19,74 & 20 \\
20 & controle & 16 & 16,97 \\
21 & controle & 22,54 & 15 \\
22 & controle & 17,38 & 16,93 \\
23 & controle & 22,07 & 17,48 \\
24 & controle & 19,62 & 13,74 \\
\hline * Exp: experimental & & \\
\hline
\end{tabular}

* Exp: experimental 


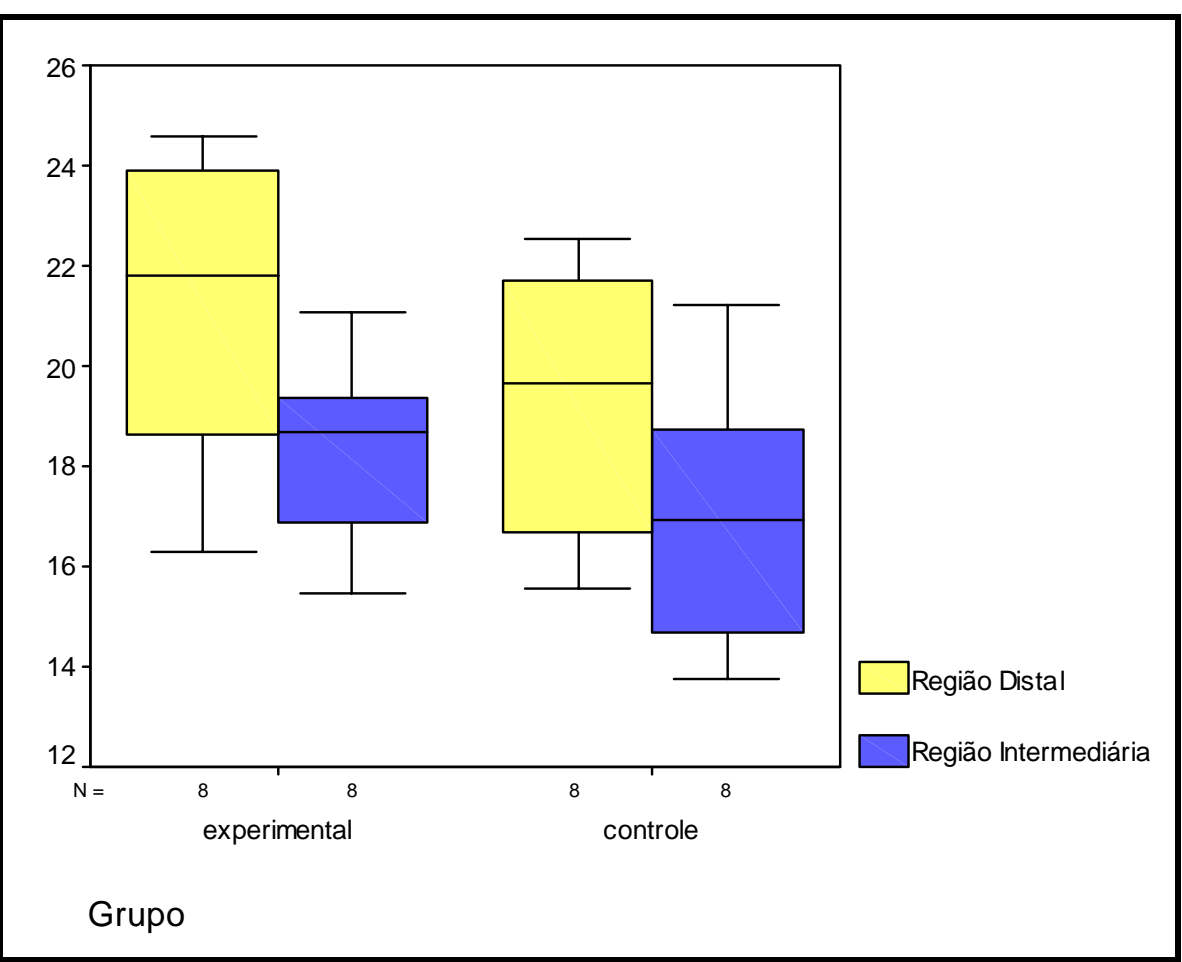

Gráfico 7 - Diferença das alturas celulares das glândulas da região distal e intermediária entre os grupos experimental e controle.

Tabela 15: Análise estatística da diferença das alturas celulares das glândulas da região distal e intermediária entre os grupos experimental e controle

\begin{tabular}{|c|c|c|c|c|c|c|}
\hline \multirow{2}{*}{$\begin{array}{c}\text { Medida } \\
\text { Região distal }\end{array}$} & \multicolumn{2}{|c|}{$\begin{array}{l}\text { Experimental } \\
\text { Média / dp }\end{array}$} & \multicolumn{2}{|c|}{$\begin{array}{l}\text { Controle } \\
\text { Média / dp }\end{array}$} & \multirow{2}{*}{$\begin{array}{c}\mathbf{t} \\
1,321\end{array}$} & \multirow{2}{*}{$\frac{\mathbf{p}}{0,208^{\mathrm{ns}}}$} \\
\hline & 21,19 & 3,04 & 19,28 & 2,71 & & \\
\hline Região intermediária & 18,29 & 1,94 & 16,96 & 2,63 & 1,143 & $0,272^{\text {ns }}$ \\
\hline
\end{tabular}

${ }^{\text {ns }}$ diferença estatística não significante. 


\subsection{4 - Percentual de fibras colágenas nas gengivas}

Com relação ao percentual de fibras colágenas, o grupo experimental dos machos apresentou maior percentual em relação ao grupo controle, enquanto as fêmeas do grupo controle apresentaram maior percentual do que as do grupo experimental. Não foi observada diferença estatística entre os grupos.

Tabela 16 - Análise morfométrica das fibras colágenas nas gengivas dos machos no grupo experimental e controle.

\begin{tabular}{|c|c|c|c|c|c|}
\hline Grupo & $\begin{array}{c}\sum \underset{\text { fos }}{\text { Fibras }} 10 \\
\text { colágenas }\end{array}$ & $\begin{array}{l}\text { campos } \\
\text { Outrost }\end{array}$ & $\begin{array}{c}\text { coletados } \\
\text { Músculos e } \\
\text { epitélio } \\
\end{array}$ & $\begin{array}{c}\sum \text { de fibras colágenas } \\
\text { e outros }\end{array}$ & $\begin{array}{l}\% \text { fibras } \\
\text { colágenas }\end{array}$ \\
\hline Exp* $^{*}$ & 483 & 397 & 120 & 880 & 54,88 \\
\hline Exp* & 361 & 311 & 328 & 672 & 53,72 \\
\hline $\operatorname{Exp}^{*}$ & 404 & 387 & 209 & 791 & 51,07 \\
\hline Exp* & 429 & 446 & 125 & 875 & 49,02 \\
\hline Exp $^{*}$ & 429 & 284 & 287 & 713 & 60,16 \\
\hline $\operatorname{Exp}^{*}$ & 527 & 356 & 117 & 883 & 59,68 \\
\hline Exp* $^{*}$ & 494 & 275 & 231 & 769 & 64,23 \\
\hline Exp $^{*}$ & 494 & 334 & 172 & 828 & 59,66 \\
\hline Controle & 363 & 250 & 387 & 613 & 59,21 \\
\hline Controle & 345 & 307 & 348 & 652 & 52,91 \\
\hline Controle & 333 & 289 & 378 & 622 & 53,53 \\
\hline Controle & 398 & 291 & 311 & 689 & 57,76 \\
\hline Controle & 360 & 223 & 417 & 583 & 61,74 \\
\hline Controle & 537 & 418 & 45 & 955 & 56,23 \\
\hline Controle & 559 & 296 & 145 & 855 & 65,38 \\
\hline
\end{tabular}

† Outros: vasos sanguíneos, células do tecido conjuntivo, espaços vazios.

* Exp: experimental 
Tabela 17 - Análise morfométrica das fibras colágenas nas gengivas das fêmeas no grupo experimental e controle

\begin{tabular}{|c|c|c|c|c|c|}
\hline Grupo & $\begin{array}{c}\sum \underset{\text { fos }}{\text { Fibras }} 10 \\
\text { colágenas }\end{array}$ & $\begin{array}{l}\text { campos } \\
\text { Outrost }\end{array}$ & $\begin{array}{l}\text { coletados } \\
\text { Músculos e } \\
\text { epitélio }\end{array}$ & $\begin{array}{c}\sum \text { de fibras colágenas } \\
\text { e outros }\end{array}$ & $\begin{array}{l}\text { \% fibras } \\
\text { colágenas }\end{array}$ \\
\hline Exp $^{*}$ & 327 & 336 & 337 & 663 & 49,32 \\
\hline $\operatorname{Exp}^{*}$ & 402 & 312 & 286 & 714 & 56,3 \\
\hline $\operatorname{Exp}^{*}$ & 388 & 303 & 309 & 691 & 56,15 \\
\hline Exp* & 346 & 371 & 283 & 717 & 48,25 \\
\hline $\operatorname{Exp}^{*}$ & 438 & 290 & 272 & 728 & 60,16 \\
\hline $\operatorname{Exp}^{*}$ & 467 & 254 & 279 & 721 & 64,77 \\
\hline $\operatorname{Exp}^{*}$ & 409 & 252 & 339 & 661 & 61,87 \\
\hline $\operatorname{Exp}^{*}$ & 462 & 244 & 294 & 706 & 65,43 \\
\hline Controle & 384 & 287 & 329 & 671 & 57,22 \\
\hline Controle & 399 & 278 & 323 & 677 & 58,93 \\
\hline Controle & 464 & 308 & 228 & 772 & 60,1 \\
\hline Controle & 352 & 318 & 330 & 670 & 52,53 \\
\hline Controle & 402 & 322 & 276 & 724 & 55,52 \\
\hline Controle & 450 & 322 & 228 & 772 & 58,29 \\
\hline Controle & 457 & 280 & 346 & 737 & 62 \\
\hline Controle & 543 & 270 & 187 & 813 & 66,78 \\
\hline
\end{tabular}

† Outros: vasos sanguíneos, células do tecido conjuntivo, espaços vazios.

* Exp: experimental 


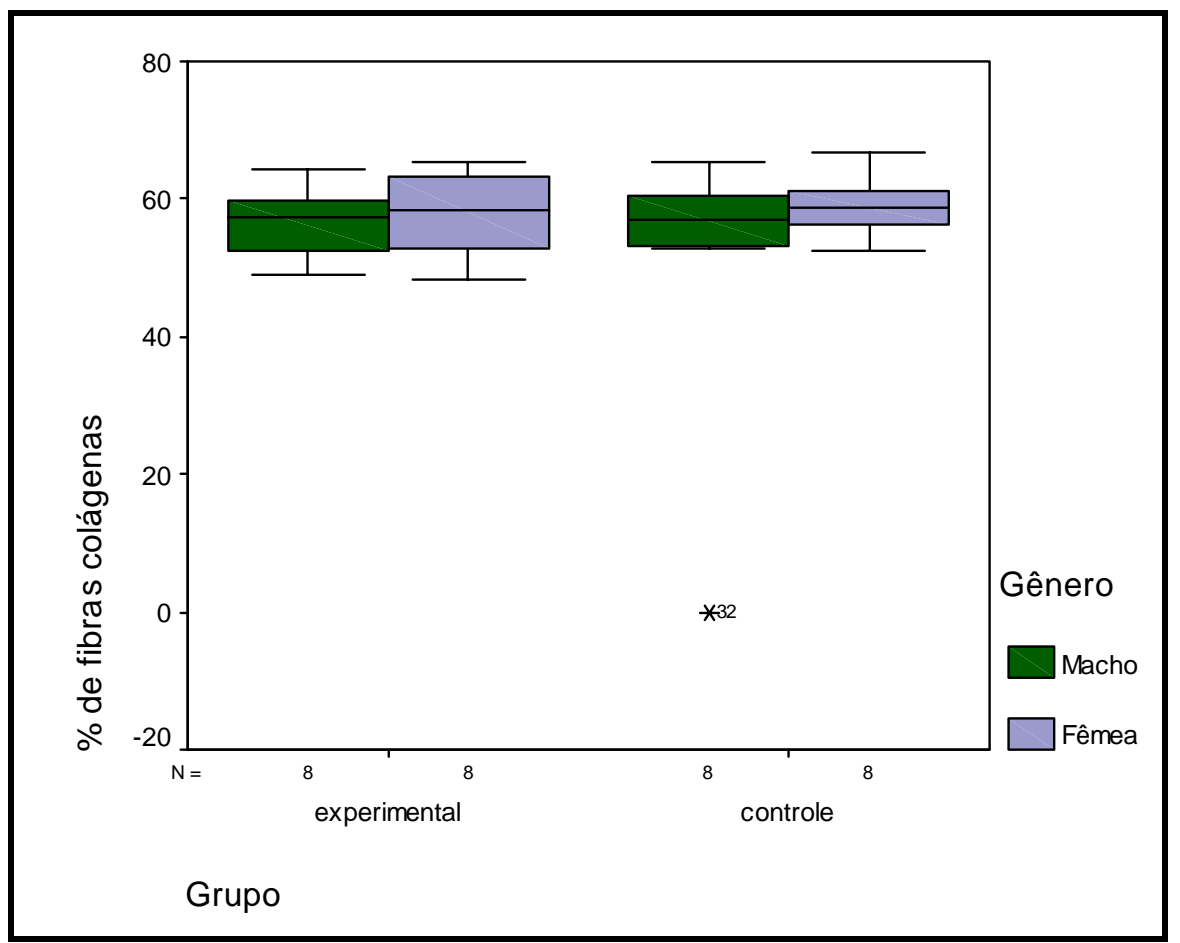

Gráfico 8 - Diferença do percentual de fibras colágenas dos machos e fêmeas, entre os grupos experimentais e controles.

Tabela 18 - Análise estatística da diferença do percentual de fibras colágenas entre os grupos experimentais e controles dos machos e fêmeas.

\begin{tabular}{ccccccc}
\hline \multicolumn{1}{c}{ Medida } & \multicolumn{1}{c}{$\begin{array}{c}\text { Experimental } \\
\text { Média / dp }\end{array}$} & $\begin{array}{c}\text { Controle } \\
\text { Média / dp }\end{array}$ & t & p \\
\hline $\begin{array}{c}\text { \% fibras colágenas } \\
\text { Machos }\end{array}$ & 56,55 & 5,19 & 50,84 & 20,95 & 0,748 & $0,467^{\text {ns }}$ \\
$\begin{array}{c}\text { \% fibras colágenas } \\
\text { Fêmeas }\end{array}$ & 57,78 & 6,51 & 58,92 & 4,28 & $-0,414$ & $0,685^{\text {ns }}$ \\
\hline ns diferença estatística não significante.
\end{tabular}




\section{4 - Análise morfológica dos ovários}

Os ovários foram analisados quantos às suas características morfológicas gerais (Figura 18), não levando em consideração o ciclo estral das ratas.

O epitélio na superfície ovariana das ratas do grupo experimental se apresentou ora cúbico com uma camada, ora cilíndrico pseudoestratificado (Figura 19), enquanto nas ratas do grupo controle foi possível observar a manutenção do epitélio cúbico com apenas uma camada.

No grupo experimental observou-se número reduzido de corpo lúteo. Em alguns casos não foi possível encontrar corpo lúteo, enquanto em outros se detectou um a dois corpos lúteos que se apresentavam em regressão e com atividade macrofágica (Figuras 20 e 21).

Nas ratas tratadas com EAA, os folículos, principalmente antrais, se apresentaram atrésicos, com células hipertróficas, desprendidas para o lume, com núcleos picnóticos e com figuras sugestivas de morte celular. E ainda, redução do número e tipos de folículos (Figuras 22 e 23). 


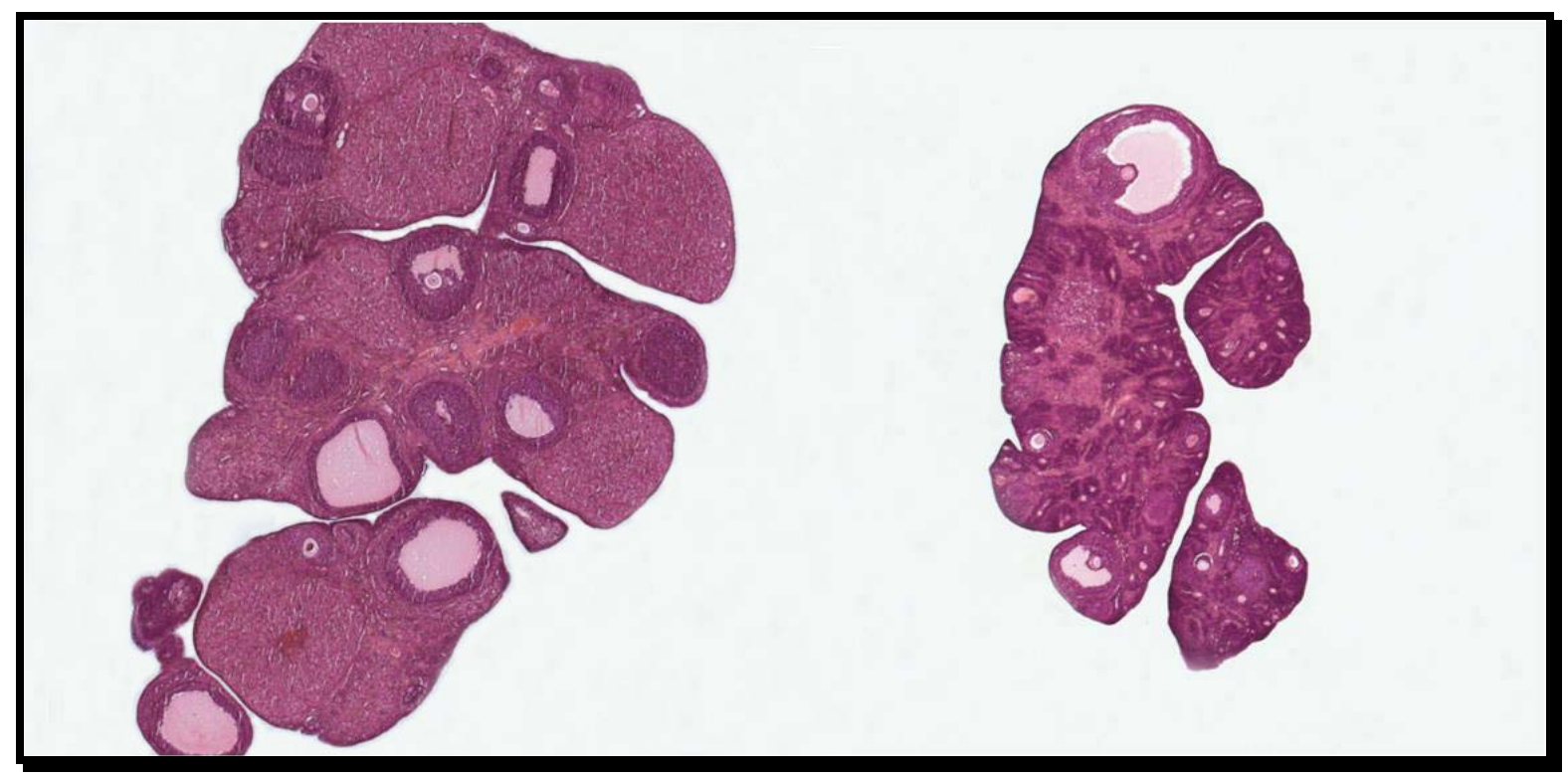

Figura 18 - Ovário do grupo controle exibindo morfologia normal (esq.) e ovário do grupo experimental exibindo menor tamanho, poucos folículos e corpo lúteo em regressão (dir.) - HE obj. $2,5 x$.

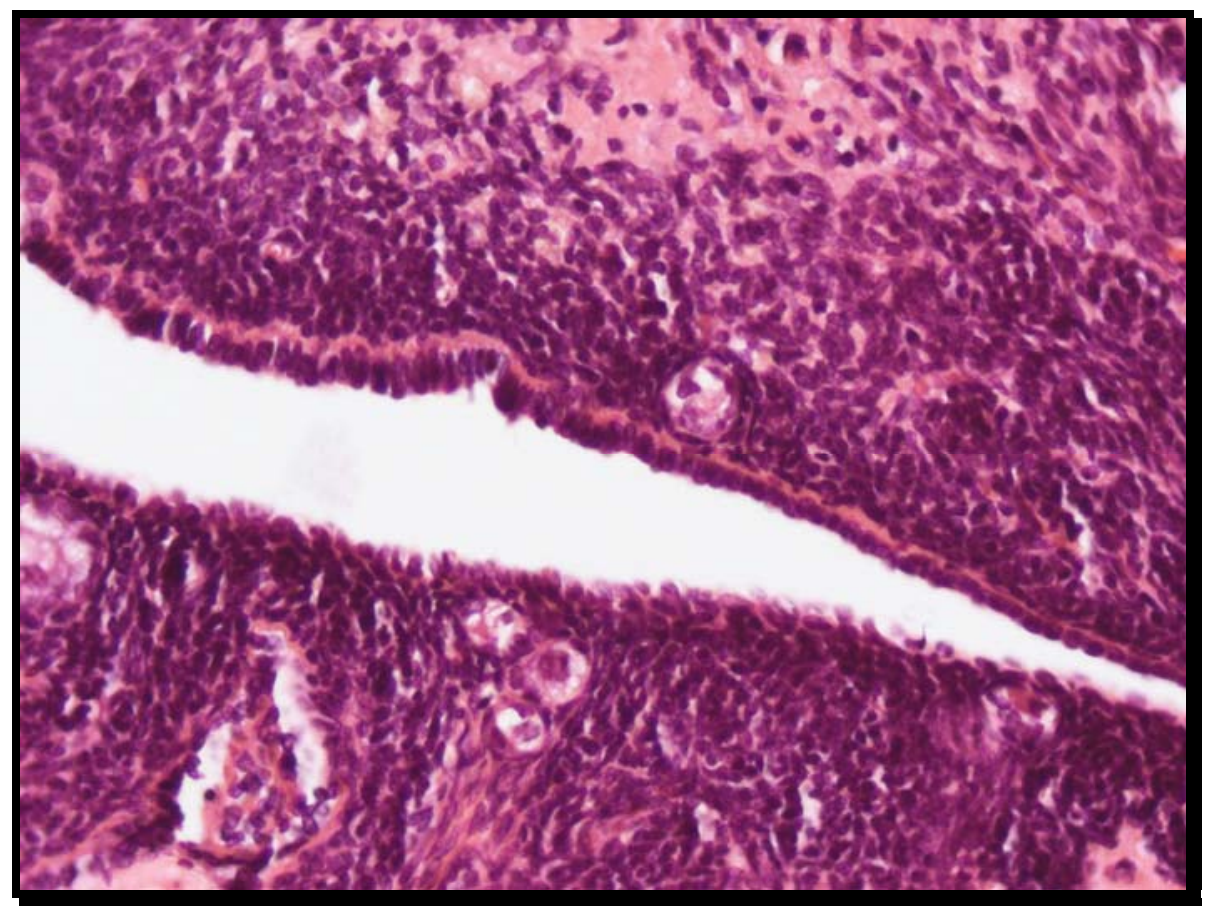

Figura 19 - Epitélio ovariano do grupo experimental variando de cúbico simples a cilíndrico pseudoestratificado - HE obj. 10x. 


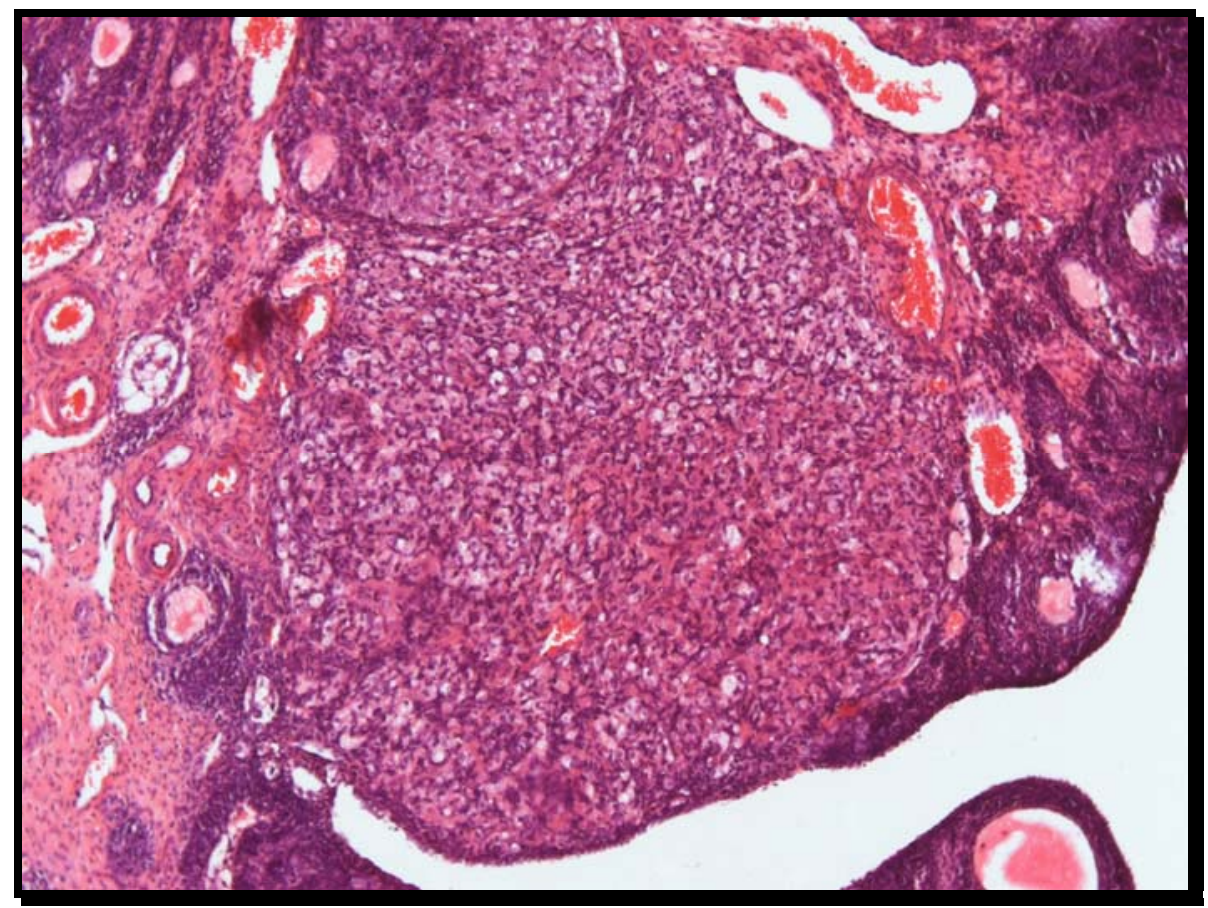

Figura 20 - Corpo lúteo do ovário do grupo experimental (HE obj. 10X).

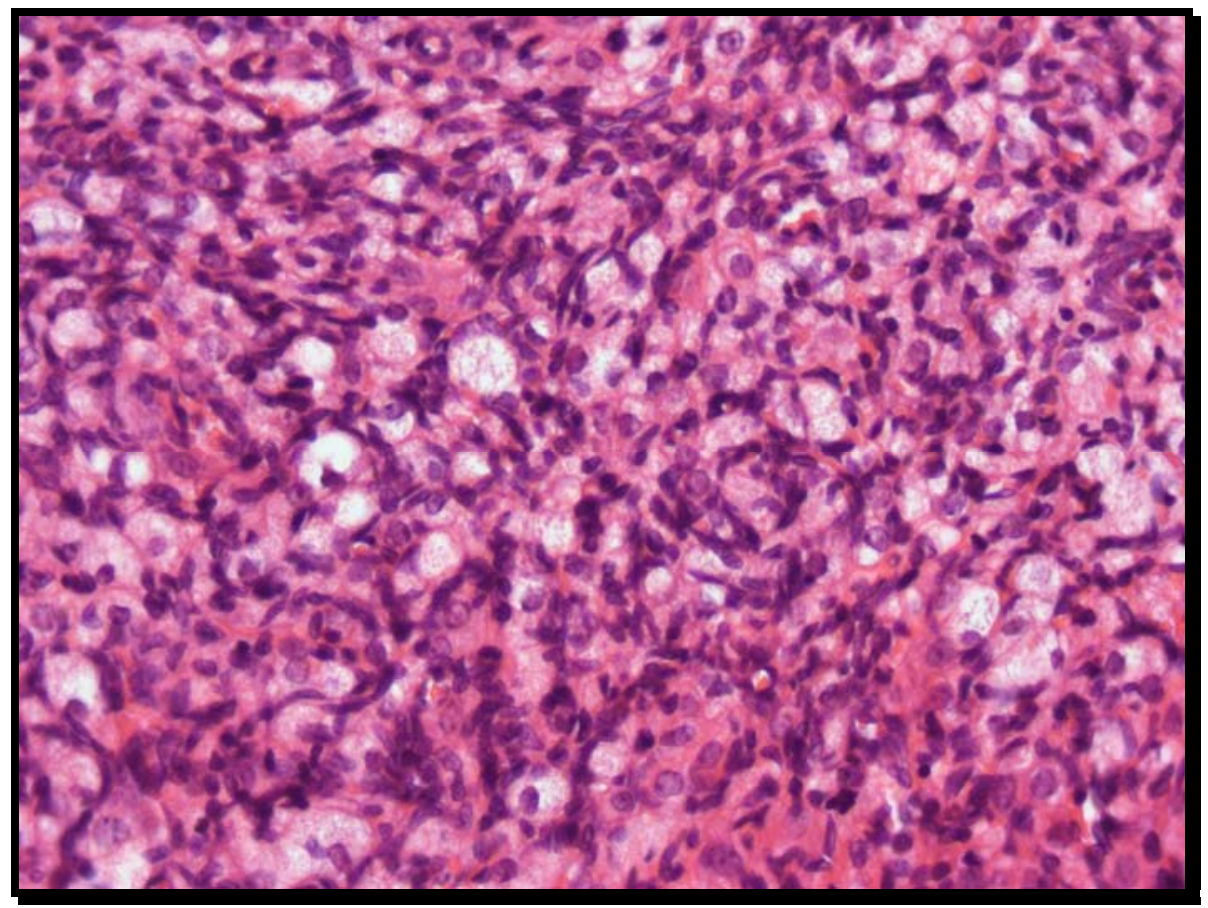

Figura 21 - Corpo lúteo do ovário do grupo experimental exibindo regressão e atividade macrofágica (HE obj. 40X). 


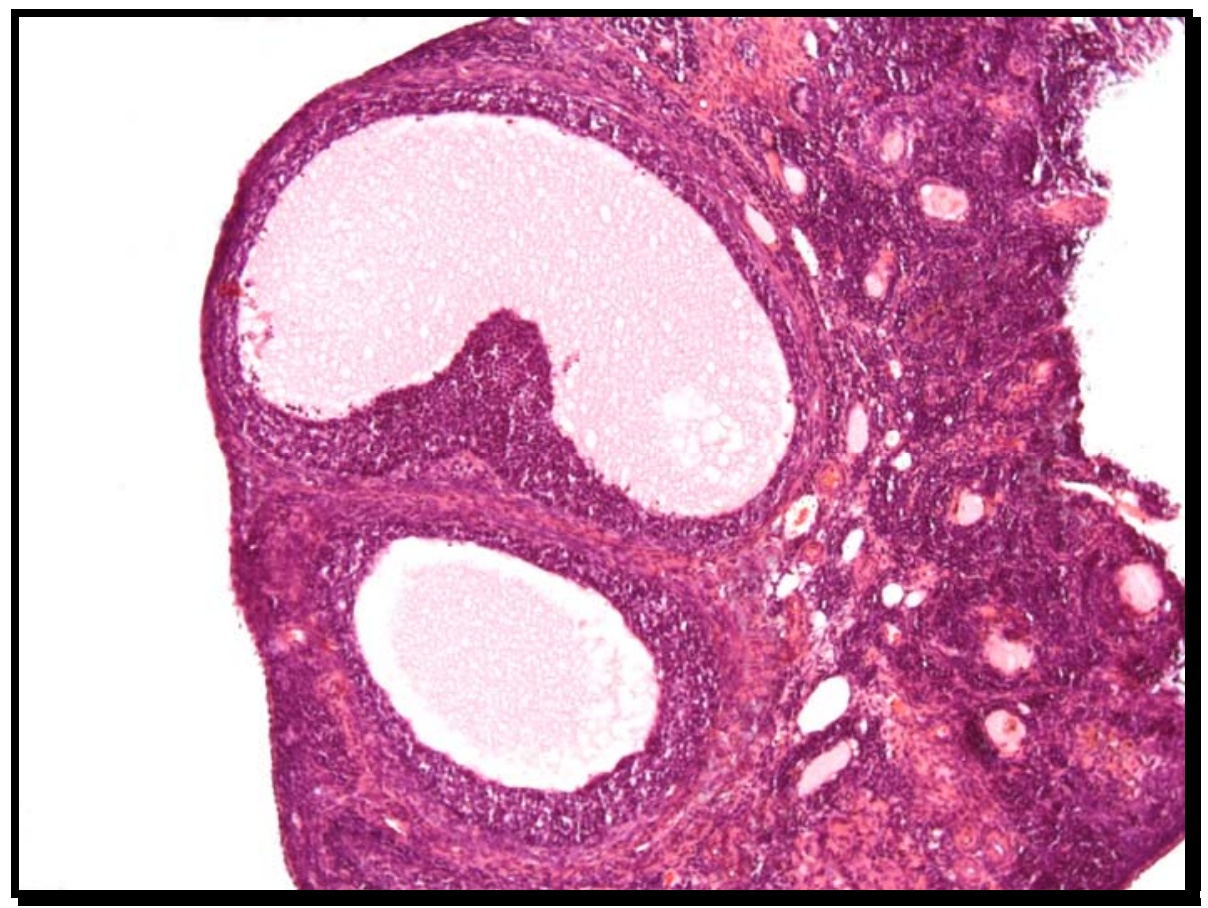

Figura 22 - Folículos atrésicos do ovário do grupo experimental - HE obj. 10x.

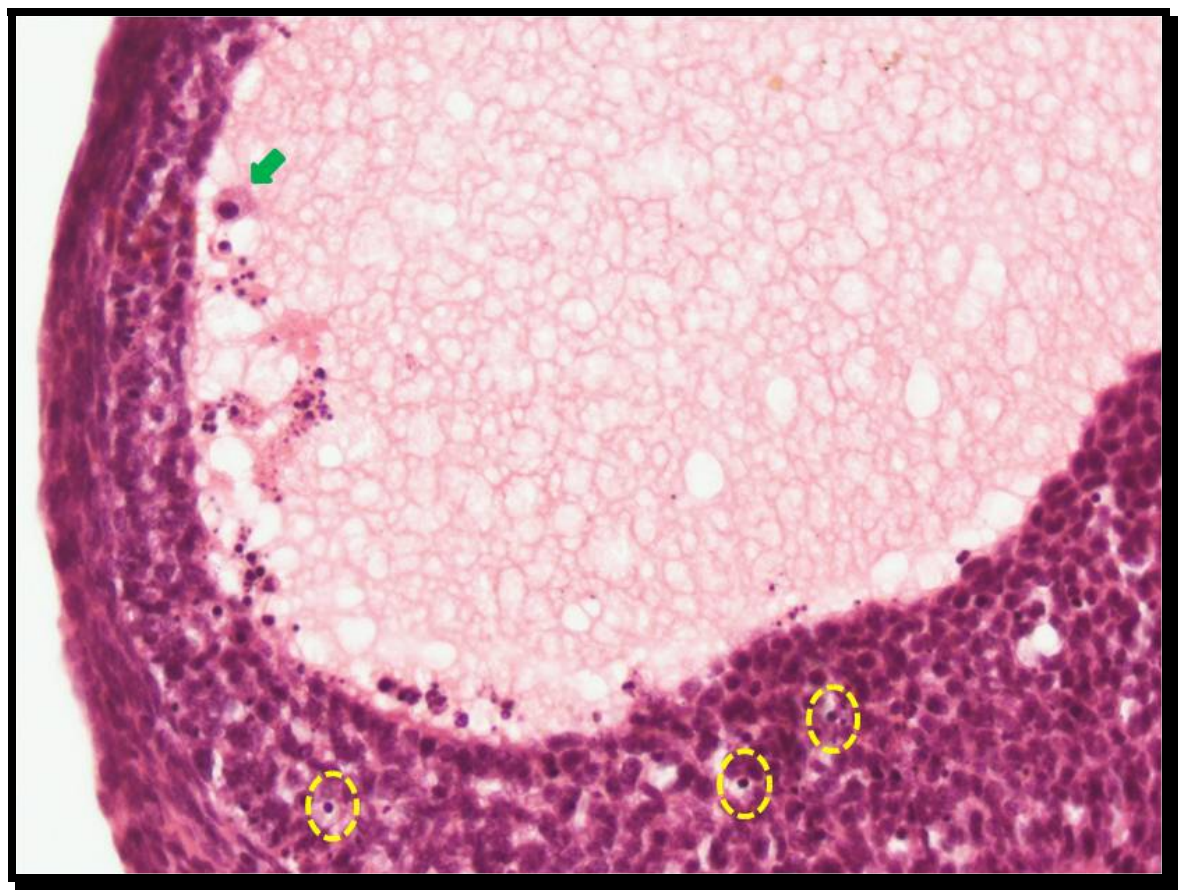

Figura 23 - Célula com hipertrofia (seta verde) e figuras sugestivas de morte celular desprendidas no lume e circundadas pelo halo amarelo em folículo atrésico do ovário do grupo experimental - HE obj. 40x. 
6 DISCUSSÃO 


\section{6 - DISCUSSÃO}

\section{Concepção do trabalho}

O uso indiscriminado de EAA por atletas profissionais e amadores vem crescendo e já se tornou um problema sóciogovernamental. Aproximadamente três milhões de homens e mulheres usam anabolizante só nos Estados Unidos, com o objetivo de melhorar o desempenho atlético, ou apenas para fins estéticos. Muitas vezes, sem conhecimento profundo, esses indivíduos acabam por desenvolver diversas alterações e doenças.

Este trabalho, desenvolvido em conjunto com as disciplinas de Anatomia e Bioquímica, surgiu na tentativa de aprofundar o conhecimento e no entendimento da ação dos EAA no organismo dos animais de laboratório. Além dos efeitos de doses suprafisiológicas de esteróides no sistema reprodutor feminino e masculino; e na síntese de colágeno descritos neste trabalho, outros órgãos também foram removidos como fígado, rins e coração. A análise deste material será parte de outra tese que será desenvolvida futuramente. A ação dos anabolizantes também foi analisada nos músculos digástrico (ventre anterior), masseter (porção superficial) e tibial anterior; no esqueleto cefálico, na mandíbula e fêmur - trabalho que vem sendo desenvolvido pela disciplina de Anatomia - e no sangue com a dosagem da fosfatase alcalina.

O uso da dose suprafisiológica de decanoato de nandrolona, um dos anabolizantes mais utilizados nas academias, teve como objetivo estar em equivalência às doses elevadas, geralmente utilizadas por atletas $-600 \mathrm{mg} / \mathrm{semana}$ ou aproximadamente $8 \mathrm{mg} / \mathrm{kg} / \mathrm{semana}$ (POPE e KATZ, 1988). Com a dose acima do recomendado os efeitos colaterais do medicamento seriam extrapolados, confirmando com a literatura, os malefícios do mesmo quando mal utilizado. 


\section{Peso dos animais}

Os animais do grupo controle do presente trabalho, chegaram ao final do experimento com peso mais elevado do que os do grupo experimental, assim como demonstrado por Takahashi et al. (2004) e Lindqvist e Fahlke (2005). No entanto, outros estudos obtiveram resultados diferentes, onde os grupos experimentais adquiriram maior peso final (BLASBERG et al., 1997; BRONSON et al., 1996; GEREZ et al., 2005; MOBINI FAR et al., 2007). A administração de testosterona em ratos machos aumenta a resposta dos adipócitos para as catecolaminas devido a elevada expressão de receptores beta-adrenérgicos e com isso intensifica a lipólise (XU et al., 1991). Com elevação da quebra de gordura e o controle de ração realizado durante o presente experimento, justifica-se o reduzido ganho de peso pelos ratos tratados com a medicação, mesmo sem a realização de exercícios físicos. No entanto, ainda não há completo esclarecimento em relação ao efeito dos EAA na massa muscular e nas suas funções quando os usuários não fazem uso de exercícios físicos. Estudos com ratos mostraram ausência de efeitos ou diminuição da massa muscular e do peso corporal com a utilização de EAA (BAUMAN et al., 1988), Bronson et al. (1996) observaram um aumento da massa gordurosa nas ratas tratadas com EAA sem que elas tivessem aumentado a ingestão de comida.

No estudo de Lindqvist e Fahlke em 2005, o peso dos animais tratados com decanoato de nandrolona foi menor do que o dos animais controle, ocorrendo diminuição do peso até 8 semanas após o final do tratamento. Os autores acreditam que o menor ganho de peso tenha relação com a menor ingestão de alimentos. Lindblom et al. (2003), quando aplicaram a mesma metodologia utilizada neste trabalho quanto ao controle da ração, demonstraram não existir diferença no ganho de peso entre o grupo tratado com decanoato de nandrolona e o grupo controle. Também descrevem que o tratamento com decanoato de nandrolona reduz os níveis de RNAm da $\beta$-endorfina precursora da Proopiomelanocortina (POMC), que se caracteriza como pró-hormônio para o hormônio melanócito-estimulante, que participa da homeostasia de peso corporal.

O controle da ração ocorreu por interesse da disciplina de Anatomia nos músculos mastigatórios, com isso evitar-se-ia que os animais dos Grupos Experimentais consumissem mais ração do que os animais dos Grupos Controles, e 
desta maneira tivessem um ciclo mastigatório maior que poderia ser considerado como um exercício físico extra, comprometendo os resultados obtidos na pesquisa.

\section{Gengivas}

O uso de EAA no reparo de feridas tem recebido grande atenção na medicina. A utilização do decanoato de nandrolona no pré e pós-operatório de incisões intestinais em ratos foi capaz de reverter os efeitos deletérios dos corticosteróides no reparo das feridas sem que houvesse qualquer efeito colateral do EAA (KIM et al., 1993). Falanga et al. (1991) observaram uma grande recuperação em úlceras isquêmicas em pacientes com o uso de estanozolol, considerado um EAA com grandes propriedades fibrinolíticas. Todos os pacientes obtiveram notável e rápido alívio de dor e reparo das feridas.

Os machos do grupo experimental do presente trabalho obtiveram maior percentual de fibras colágenas do que o grupo controle. No entanto, o mesmo não ocorreu com as fêmeas do grupo experimental em relação ao controle. A variação hormonal teria influência nesses resultados? Assim, neste trabalho não foi possível concluir o benefício causado pelos EAA na síntese de colágenos como afirmado por Kim et al. (1993) e Falanga et al. (1991).

O uso de EAA em cirurgias periodontais ou em feridas nas gengivas não é relatado ainda na literatura mundial. Embora se observe inúmeros efeitos adversos dos anabolizantes, sua utilização no reparo pode trazer uma melhor recuperação de feridas cirúrgicas no periodonto para os pacientes que utilizam corticosteróides há muito tempo. As doses e frequência do seu uso seriam menores do que aquelas utilizadas pelos atletas profissionais ou não e, portanto, sem a possibilidade de causar os inúmeros efeitos nocivos já bem descritos na literatura.

\section{Testículos e próstatas}

O uso de EAA, isto é, administração exógena de testosterona sintética em homens, diminui os níveis do hormônio luteinizante (LH) e do hormônio folículo- 
estimulante (FSH) resultante de um "feedback" negativo no eixo hipotalâmicopituitário-gonodal levando a uma diminuição da produção endógena de testosterona, atrofia testicular, diminuição da espermatogênese e/ou azoospermia. Com o uso de EAA é possível manter uma concentração sérica normal de andrógenos, mesmo com a diminuição na produção endógena da testosterona, porém não suficiente nos testículos, onde seria necessária uma concentração maior para a manutenção da espermatogênese (DOHLE et al., 2003; NOORAFSHAN et al., 2005). No presente trabalho, encontrou-se uma diminuição significativa de peso e do tamanho macroscópico dos testículos, logo após a remoção dos mesmos nos animais que receberam doses suprafisiológicas de decanoato de nandrolona, quando comparados aos do grupo controle, dados que concordam com aqueles encontrados por Fortunato et al. (2006).

A detecção de achados patológicos nos órgãos andrógenos-dependentes indica que os EAA tiveram ação profunda causando danos muitas vezes irreversíveis. Nos testículos, o número de células de Sertoli do grupo experimental apresentou-se maior do que no grupo controle, tanto nos túbulos em fase de préespermiação quanto nos em fase de pós-espermiação. Takahashi et al. (2004) observaram diminuição do números das células de Sertoli e das de Leydig, assim como um grande dano na morfologia dos testículos. O resultado obtido pelos autores é o esperado quando há uso indevido dos EAA com doses acima do permitido, já que ocorre um "feedback" negativo inibindo a produção endógena de testosterona e com isso concentração menor da mesma nos testículos. Noorafshan et al. (2005) observaram alterações estruturais nos testículos de animais que receberam decanoato de nandrolona por 14 semanas, mesmo após um intervalo de mais 14 semanas sem a medicação. No presente trabalho, uma das possibilidades para o resultado encontrado, que discorda da literatura, pode ser a perda de tecido devido à manipulação das peças durante todo o processamento histológico. Durante a coleta dos resultados observou-se inúmeros túbulos expandidos e com células desprendidas, o que pode corroborar com nossa hipótese.

Macroscopicamente, detectou-se aumento de tamanho nas próstatas dos ratos experimentais, sugerindo hipertrofia do órgão. Os dados coletados após a morfometria das alturas celulares do epitélio glandular na região distal e intermediária demonstraram um aumento na altura dessas células no grupo experimental, o que confirma a hipertrofia. Takahashi et al. (2004) observaram 
hipertrofia macroscópica e hipertrofia adenomatosa principalmente no lobo dorsolateral, que não foi incluído no presente experimento. Embora sem diferença estatística, Karbalay-Doust e Noorafshan (2006) encontraram resultado diferente em relação à altura do epitélio. Esta, nos animais tratados apresentou-se ligeiramente menor que no grupo controle. A diferença nos resultados pode estar relacionada com a dose utilizada e/ou a duração do tratamento.

\section{Úteros e Ovários}

A influência do medicamento no sistema reprodutor feminino pôde ser observada logo após a eutanásia e remoção dos órgãos. Macroscopicamente, os úteros das ratas do grupo experimental apresentaram notável aumento de volume, o que também foi observado durante a pesagem dos mesmos. Os úteros do grupo experimental apresentaram-se, em média, com aproximadamente mais da metade $(57,8 \%)$ do peso dos órgãos das ratas do grupo controle. Bronson et al. (1996) também encontram resultado semelhante, onde a média de peso dos úteros das ratas tratadas foi de três a quatro vezes maiores do que nas ratas do grupo controle, embora as primeiras não estivessem ciclando, assim como as do presente experimento.

A administração de decanoato de nandrolona em ratas produz um aumento da espessura no miométrio e uma atrofia do endométrio (MOBINI FAR et al., 2007). No presente experimento observou-se aumento da espessura do miométrio das ratas tratadas, assim como no endométrio. Os receptores androgênicos expressos pelas células do músculo liso podem estar envolvidos na hipertrofia uterina (MERTENS et al., 1996). No entanto, essas alterações morfológicas também podem estar relacionadas com o efeito semelhante ao estrogênio e a progesterona que o decanoato de nandrolona provoca, já que são vistas também durante a gravidez e estão associadas a altos níveis desses hormônios, o que também poderia justificar o aumento da espessura observado no endométrio.

Alterações na atividade cíclica do ovário são resultados esperados quando há o tratamento com EAA, já que, assim como nos gênero masculino, 
também ocorrem disfunções no eixo hipotalâmico-pituitário-gonadal e em conseqüência, a secreção de estrógenos para os ovários apresenta-se reduzida. Esse fato pode sugerir que a redução de estrógenos circulantes, indiretamente, leva a um padrão diestro no ciclo das ratas, onde há a presença de numerosos corpos lúteos e um período sexualmente não receptivo.

Embora neste trabalho o controle dos ciclos estrais não tenha sido realizado, foi possível observar que as fêmeas tratadas não apresentavam nenhum ou no máximo um a dois corpos lúteos, folículos em atresia e reduzidos quanto ao seu número, sugerindo a caracterização de anestro ou ausência de ciclo. As características observadas nos ovários apresentam concordância com os resultados encontrados por Gerez et al. (2005). No entanto Blasberg et al. (1997) observaram a manutenção do diestro nas ratas do grupo tratado com a dose mais elevada do Decanoato de Nandrolona, $7,5 \mathrm{mg} / \mathrm{kg}$ diário, por duas semanas.

Diversos efeitos colaterais ocorrem no sistema reprodutor e no comportamento sexual masculino e feminino pelo uso incorreto dos EAA. Marcantes diferenças existem em como os hormônios sexuais influenciam no comportamento de humanos e ratos. Por isso, os resultados encontrados no presente trabalho e na literatura mundial devem ser interpretados com cautela. 


\section{CONCLUSÕES}




\section{7 - CONCLUSÕES}

A partir dos objetivos propostos, conclui-se que:

- A dose do medicamento quando administrada acima do recomendado causa alterações no sistema reprodutor feminino e masculino;

- A presença do hormônio exógeno resultou no "feedback" negativo diminuindo a produção endógena e assim sua concentração nos órgãos, levando a atrofia macroscópica observada nos testículos e ovários. Nas ratas, apesar do ciclo estral não ter sido controlado, esta atrofia e a morfologia dos ovários sugerem alteração no ciclo.

- A presença de receptores andrógenos no músculo liso pode sugerir a hipertrofia observada nos úteros e nas próstatas.

- $\quad$ Apesar do aumento de fibras colágenas observado nos machos do grupo experimental, não é possível sugerir que a administração do decanoato de nandrolona tenha efeito benéfico na síntese de colágeno, pois nas fêmeas experimentais este aumento não foi obeservado. 



\section{REFERÊNCIAS}

Bagatell CJ, Bremner WJ. Androgens in men--uses and abuses. N Engl J Med. 1996 Mar 14;334(11):707-14.

Bahrke MS, Yesalis CE, Brower KJ. Anabolic-androgenic steroid abuse and performance-enhancing drugs among adolescents. Child Adolesc Psychiatr Clin N Am. 1998 Oct;7(4):821-38.

Barrett, RL, Harris, EF. Anabolic steroids and craniofacial growth in the rat. Angle Orthod. 1993; 63(4):289-98.

Basaria S, Wahlstrom JT, Dobs AS. Clinical review 138: Anabolicandrogenic steroid therapy in the treatment of chronic diseases. J Clin Endocrinol Metab. 2001 Nov;86(11):5108-17.

Bauman DH, Richerson JT, Britt AL. A comparison of body and organ weights, physiological parameters, and pathologic changes in target organs of rats given combinations of exercise, anabolic hormone, and protein supplementation. Am J Sports Med. 1988; 16:397-402.

Bhasin S, Storer TW, Berman N, Callegari C, Clevenger B, Phillips J, Bunnell TJ, Tricker R, Shirazi A, Casaburi R. The effects of supraphysiologic doses of testosterone on muscle size and strength in normal men. N Engl J Med. 1996 Jul 4;335(1):1-7.

Bhasin S, Bremner WJ. Clinical review 85: Emerging issues in androgen replacement therapy. J Clin Endocrinol Metab. 1997 Jan;82(1):3-8.

Bhasin S, Woodhouse L, Casaburi R, Singh AB, Bhasin D, Berman N, Chen X, Yarasheski KE, Magliano L, Dzekov C, Dzekov J, Bross R, Phillips J, SinhaHikim I, Shen R, Storer TW. Testosterone dose-response relationships in healthy young men. Am J Physiol Endocrinol Metab. 2001 Dec;281(6):E1172-81.

Blasberg ME, Langan CJ, Clark AS. The effects of 17 alphamethyltestosterone, methandrostenolone, and nandrolone decanoate on the rat estrous cycle. Physiol Behav. 1997 Feb;61(2):265-72. 
Brodsky IG, Balagopal P, Nair KS. Effects of testosterone replacement on muscle mass and muscle protein synthesis in hypogonadal men--a clinical research center study. J Clin Endocrinol Metab. 1996 Oct;81(10):3469-75.

Bronson FH, Nguyen KQ, De La Rosa J. Effect of anabolic steroids on behavior and physiological characteristics of female mice. Physiol Behav. 1996 Jan;59(1):49-55.

Bronson $\mathrm{FH}$, Matherne $\mathrm{CM}$. Exposure to anabolic-androgenic steroids shortens life span of male mice. Med Sci Sports Exerc. 1997 May;29(5):615-9.

Brunton L, Lazo J, Parker K. Goodman \& Gilman's: The Pharmacological Basis of Therapeutics. $11^{\mathrm{a}}$ ed. 2006

Clark AS, Fast AS. Comparison of the effects of 17 alphamethyltestosterone, methandrostenolone, and nandrolone decanoate on the sexual behavior of castrated male rats. Behav Neurosci. 1996 Dec;110(6):1478-86.

Conway AJ, Handelsman DJ, Lording DW, Stuckey B, Zajac JD. Use, misuse and abuse of androgens. The Endocrine Society of Australia consensus guidelines for androgen prescribing. Med J Aust. 2000 Mar 6;172(5):220-4.

Creutzberg EC, Schols AMWJ. Anabolic steroids. Curr Opin Clin Nutr Metab Care 1999;2(3):243-53.

Cross PC, Mercer K L. Spermatogenesis In: Cell and Tissue Ultrastructure - A Functional perspective, Freeman, W. H. and Co, Ltd. England, 1993 pp. 336-350.

Cunha TS, Cunha NS, Moura MJCS, Marcondes FK. Esteróides anabólicos androgênicos e sua relação com a prática desportiva. Rev Bras Ciênc Farmac 2004;40(2):165-79.

Cunha, TS; Tanno, AP; Marcondes, FK; Perez. SEA; Selistre-Araujo, HS. A administração de Nandrolona não promove hipertrofia do músculo sole em ratos. Arq Brás Endocrinol Metabo., 50(3): 532-540, 2006.

Da Silva PRP, Czepielewski MA. Uso de agentes esteróides anabólicos, estimulantes, diuréticos, insulina e GH em amostra de praticantes de musculação de Porto Alegre. Ver Brás Toxicol 2001;14(supl):71. 
Da Silva PRP, Machado LC Jr, Figueiredo VC, Cioffi AP, Prestes MC, Czepielewski MA. Prevalence of the use of anabolic agents among strength training apprentices in Porto Alegre, RS. Arq Bras Endocrinol Metabol. 2007 Feb;51(1):10410.

Dohle GR, Smit M, Weber RF. Androgens and male fertility. World J Urol. 2003 Nov;21(5):341-5.

Evans NA. Current concepts in anabolic-androgenic steroids. Am J Sports Med. 2004 Mar;32(2):534-42.

Faigenbaum AD, Zaichkowsky LD, Gardner DE, Micheli LJ. Anabolic steroid use by male and female middle school students. Pediatrics. 1998 May;101(5):E6.

Falanga V, Greenberg AS, Zhou L, Ochoa SM, Roberts AB, Falabella A, Yamaguchi Y. Stimulation of collagen synthesis by the anabolic steroid stanozolol. J Invest Dermatol. 1998 Dec;111(6):1193-7.

Falanga V, Kirsner RS, Eaglstein WH, Katz MH, Kerdel FA. Stanozolol in treatment of leg ulcers due to cryofibrinogenaemia. Lancet. 1991 Aug 10;338(8763):347-8.

Fortunato RS, Marassi MP, Chaves EA, Nascimento JH, Rosenthal D, Carvalho DP. Chronic administration of anabolic androgenic steroid alters murine thyroid function. Med Sci Sports Exerc. 2006 Feb;38(2):256-61.

Gerez JR, Frei F, Camargo IC. Histological assessment of ovaries and uterus of rats subjected to nandrolone decanoate treatment. Contraception. 2005 Jul;72(1):77-80.

Ghaphery NA. Performance-enhancing drugs. Orthop Clin North Am. 1995 Jul;26(3):433-42.

Grinspoon S, Corcoran C, Parlman K, Costello M, Rosenthal D, Anderson E, Stanley T, Schoenfeld D, Burrows B, Hayden D, Basgoz N, Klibanski A. Effects of testosterone and progressive resistance training in eugonadal men with AIDS wasting. A randomized, controlled trial. Ann Intern Med. 2000 Sep 5;133(5):348-55. 
Griswold M D. Interactions between germ cells and Sertoli cells in the testis. Biol Reprod. 1995, 52:211-216.

Griswold M D. The central role of Sertoli cells in spermatogenesis. Semin. Cell Dev Biol. 1998, 9:379-391.

Haupt HA, Rovere GD. Anabolic steroids: a review of the literature. Am J Sports Med. 1984 Nov-Dec;12(6):469-84.

Hoberman JM, Yesalis CE. The history of synthetic testosterone. Sci Am. 1995 Feb;272(2):76-81.

Jégou UB. The Sertoli cell in vivo and in vitro. Cell Biol Toxicol, 1992, 8:49-54.

Karbalay-Doust S, Noorafshan A. Stereological study of the effects of nandrolone decanoate on the rat prostate. Micron. 2006;37(7):617-23.

Kim CS, Buchmiller TL, Fonkalsrud EW, Phillips JD. The effect of anabolic steroids on ameliorating the adverse effects of chronic corticosteroids on intestinal anastomotic healing in rabbits. Surg Gynecol Obstet. 1993 Jan;176(1):73-9.

Kirsner RS, Eaglstein WH, Katz MH, Kerdel FA, Falanga V. Stanozolol causes rapid pain relief and healing of cutaneous ulcers caused by cryofibrinogenemia. J Am Acad Dermatol. 1993 Jan;28(1):71-4.

Kuhn CM. Anabolic steroids. Recent Prog Horm Res. 2002;57:411-34.

Lindblom J, Kindlundh AM, Nyberg F, Bergstrom L, Wikberg JE. Anabolic androgenic steroid nandrolone decanoate reduces hypothalamic proopiomelanocortin mRNA levels. Brain Res. 2003 Oct 3;986(1-2):139-47.

Lindqvist AS, Fahlke C. Nandrolone decanoate has long-term effects on dominance in a competitive situation in male rats. Physiol Behav. 2005 Jan 31;84(1):45-51.

Mertens $\mathrm{HJ}$, Heineman MJ, Koudstaal J, Theunissen $\mathrm{P}$, Evers JL. Androgen receptor content in human endometrium. Eur J Obstet Gynecol Reprod Biol. 1996 Dec;70(1):11-3. 
Mobini Far HR, Agren G, Lindqvist AS, Marmendal M, Fahlke C, Thiblin I. Administration of the anabolic androgenic steroid nandrolone decanoate to female rats causes alterations in the morphology of their uterus and a reduction in reproductive capacity. Eur J Obstet Gynecol Reprod Biol. 2007 Apr;131(2):189-97.

Noorafshan A, Karbalay-Doust S, Ardekani FM. High doses of nandrolone decanoate reduce volume of testis and length of seminiferous tubules in rats. APMIS. 2005 Feb;113(2):122-5.

Obasanjo IO, Cline JM, Schmotzer S, Weaver DS. Nandrolone decanoate causes pathologic changes in the uterus of surgically postmenopausal female cynomolgus macaques. Menopause. 1998 Fall;5(3):163-8.

Parssinen $M$, Karila $T$, Kovanen $V$, Seppala $T$. The effect of supraphysiological doses of anabolic androgenic steroids on collagen metabolism. Int J Sports Med. 2000 Aug;21(6):406-11.

Penatti, CAA; Porter, DM; Jones, BL; Henderson, LP. Sex-specific effects of chronic anabolic androgenic steroid treatment on gaba receptor expression and function in adolescent mice. Neuroscience. 2005, 135:533-543.

Pope, HG; Katz, DL. Affective and psychotics symptoms associated with anabolic steroid use. Am J Phychiatry. 1988 145(4):487-490,.

Rabkin JG, Wagner GJ, Rabkin R. A double-blind, placebo-controlled trial of testosterone therapy for HIV-positive men with hypogonadal symptoms. Arch Gen Psychiatry. 2000 Feb;57(2):141-7.

Rogol AD, Yesalis CE 3rd. Anabolic-androgenic steroids and the adolescent. Pediatr Ann. 1992 Mar;21(3):175, 183, 186-8.

Sattler FR, Jaque SV, Schroeder ET, Olson C, Dube MP, Martinez C, Briggs W, Horton R, Azen S. Effects of pharmacological doses of nandrolone decanoate and progressive resistance training in immunodeficient patients infected with human immunodeficiency virus. J Clin Endocrinol Metab. 1999 Apr;84(4):126876.

Sattler FR, Schroeder ET, Dube MP, Jaque SV, Martinez C, Blanche PJ, Azen S, Krauss RM. Metabolic effects of nandrolone decanoate and resistance training in men with HIV. Am J Physiol Endocrinol Metab. 2002 Dec;283(6):E121422. 
Schroor EJ, van Weissenbruch MM, Knibbe P, Delemarre-van de Waal HA. The effect of prolonged administration of an anabolic steroid (oxandrolone) on growth in boys with constitutionally delayed growth and puberty. Eur J Pediatr. 1995 Dec;154(12):953-7.

Shahidi NT. A review of the chemistry, biological action, and clinical applications of anabolic-androgenic steroids. Clin Ther. 2001, Sep;23(9):1355-90.

Snyder PJ, Peachey H, Berlin JA, Hannoush P, Haddad G, Dlewati A, Santanna J, Loh L, Lenrow DA, Holmes JH, Kapoor SC, Atkinson LE, Strom BL. Effects of testosterone replacement in hypogonadal men. J Clin Endocrinol Metab. 2000 Aug;85(8):2670-7.

Sullivan ML, Martinez CM, Gennis P, Gallagher EJ. The cardiac toxicity of anabolic steroids. Prog Cardiovasc Dis. 1998 Jul-Aug;41(1):1-15.

Takahashi M, Tatsugi Y, Kohno T. Endocrinological and pathological effects of anabolic-androgenic steroid in male rats. Endocr J. 2004 Aug;51(4):425-34.

Thein LA, Thein JM, Landry GL. Ergogenic aids. Phys Ther. 1995 May;75(5):426-39.

Xu XF, De Pergola G, Bjorntorp P. Testosterone increases lipolysis and the number of beta-adrenoceptors in male rat adipocytes. Endocrinology. 1991 Jan;128(1):379-82.

Yesalis, C.E.; Courson, S. P.; Wright, J. E. History of anabolic steroid use in sport and exercise. In: Yesalis C, editor Anabolic steroids in sport and exercise. 2 nd. Ed. Champaign (IL): Human Kinetics, 2000 p.51-72. 
ANEXO 


\section{ANEXO}

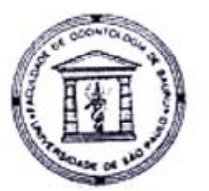

\section{Universidade de São Paulo Faculdade de Odontologia de Bauru - USP Departamento de Estomatologia - Área de Patologia Programa de Pós-Graduação em Patologia Bucal}

\section{Senhora Presidente}

Encaminhamos ao Comitê de Ética no Ensino e Pesquisa em Animais, o projeto "Ação dos anabolizantes esteróides em gengivas e nos sistemas reprodutores feminino e masculino de ratos (Rattus norvegicus) em desenvolvimento" de autoria de Karen Zavaro Balassiano sob a orientaçăo do Prof. Dr. Luis Antônio de Assis Taveira para ser avaliado do ponto de vista ético.

Como parte da documentação solicitada, declaramos estar ciente da realização da referida pesquisa nas dependências do departamento de Estomatologia, disciplina de Patologia, desta faculdade.

Sendo o que se apresenta para o momento, aproveitamos a oportunidade para reafirmar os protestos de estima e consideração.

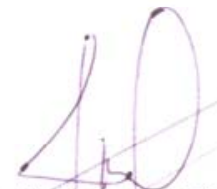

Prof. Dr. Luis Antônio de Assis Taveira

Responsável pela Disciplina de Patologia

\section{Exm. ${ }^{a} \mathrm{Sr}^{\mathrm{a}}$}

Profa. Dra. Marilia A. Rabelo Buzalaf

DD Presidente da Comissão de Ética no Ensino e Pesquisa em Animais

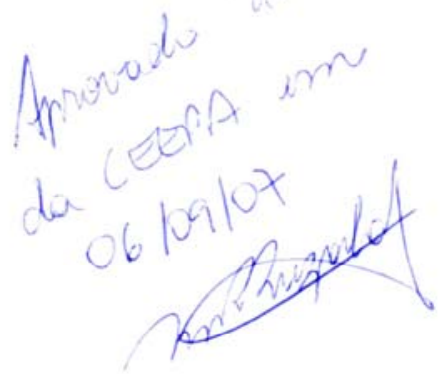

